\title{
LEVEL II CULTURAL RESOURCE INVESTIGATION FOR THE TEXOMA DISTRIBUTION ENHANCEMENTS PROJECT, CAMERON AND CALCASIEU PARISHES, LOUISIANA
}

Final Report

By

Charles H. LeeDecker

Claudia C. Holland

October 1987

Work Performed Under Contract No. AC96-85PC60004

For

Fluor Engineers, Inc.

Sugar Land, Texas

By

Berger, Barnard \& Thomas Engineering, Inc.

Baton Rouge, Louisiana 


\section{DISCLAIMER}

This report was prepared as an account of work sponsored by an agency of the United States Government. Neither the United States Government nor any agency Thereof, nor any of their employees, makes any warranty, express or implied, or assumes any legal liability or responsibility for the accuracy, completeness, or usefulness of any information, apparatus, product, or process disclosed, or represents that its use would not infringe privately owned rights. Reference herein to any specific commercial product, process, or service by trade name, trademark, manufacturer, or otherwise does not necessarily constitute or imply its endorsement, recommendation, or favoring by the United States Government or any agency thereof. The views and opinions of authors expressed herein do not necessarily state or reflect those of the United States Government or any agency thereof. 


\section{DISCLAIMER}

Portions of this document may be illegible in electronic image products. Images are produced from the best available original document. 


\section{DISCLAIMER}

This report was prepared as an account of work sponsored by an agency of the United States Government. Neither the United States Government nor any agency thereof, nor any of their employees, makes any warranty, express or implied, or assumes any legal liability or responsibility for the accuracy, completeness, or usefulness of any information, apparatus, product, or process disclosed, or represents that its use would not infringe privately owned rights. Reference herein to any specific commercial product, process, or service by trade name, trademark, manufacturer, or otherwise does not necessarily constitute or imply its endorsement, recommendation, or favoring by the United States Government or any agency thereof. The views and opinions of authors expressed herein do not necessarily state or reflect those of the United States Government or any agency thereof.

This report has been reproduced directly from the best available copy.

Availabie from the National Technical Information Service, U. S. Department of Commerce, Springfield, Virginia 22161.

Price: Printed Copy A07

Microfiche A01

Codes are used for pricing all publications. The code is determined by the number of pages in the publication. Information pertaining to the pricing codes can be found in the current issues of the following publications, which are generally available in most libraries: Energy Research Abstracts (ERA); Government Reports Announcements and Index (GRA and I); Scientific and Technical Abstract Reports (STAR); and publication NTIS-PR-360 available from NTIS at the above address. 
LEVEL II CULTURAL RESOURCE

INVESTIGATION FOR THE

TEXOMA DISTRIBUTION ENHANCEMENTS

PROJECT, CAMERON AND

CALCASIEU PARISHES, LOUISIANA

\section{FINAL REPORT}

Prepared for:

FLUOR Engineers, Inc.

Sugar Land, Texas

Contract No. $412202-0-006 \mathrm{~K}$

Prepared by:

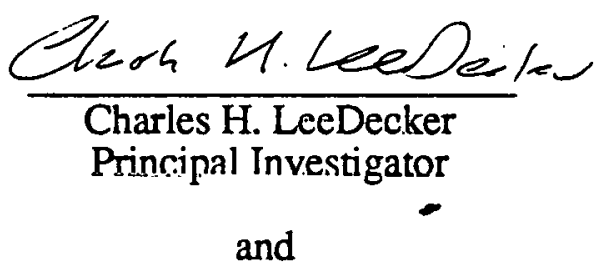

Claudia C. Holland

Berger, Barnard \& Thomas Engineering, Inc.

Baton Rouge, Louisiana

October 1987 


\section{MANAGEMENT SUMMARY}

A Level II Cultural Resource Survey was completed for the Texoma Distribution Enhancements project, located in Cameron and Calcasieu Parishes, Louisiana. The 13-mile pipeline extends from Strategic Petroleum Reserve No. 3 to a terminus near Vincent Landing. Located in Louisiana's southwest coastal zone, the pipeline will traverse extensive marsh lands as well as upland prairie terrace areas. Present land use within the project area consists primarily of undeveloped marsh land and cattle range.

The study methods included background research, intensive pedestrian survey with systematic shovel testing, a boat survey, and laboratory analysis of recovered artifact collections. While a number of sensitive areas for prehistoric resources were predicted, none were identified within the project right-of-way. This may be atrributed to the absence of high ground (relict levees or high banks) along major watercourses. One historic site, 16CU205, was identified during the field survey, and it was tested for National Register eligibility. The site is assignable to the Industrialization and Modernization (1890-1940) Cultural Unit. Archaeological testing indicates that it is a rural residence or farmstead, with a house and one outbuilding within the proposed right-of-way. The site lacks significant historical association and sufficient archaeological integrity to merit inclusion on the National Register of Historic Places. Therefore, while it will be partially destroyed by construction of the pipeline, no additional study of this resource is warranted.

Other evidence of cultural activity within the right-of-way includes a few isolated historic artifacts and a modern trash dump. These were not formally recorded as sites, and they are of no cultural significance.

Four standing structures were also identified during the field survey. The structures are agricultural outbuildings, less than 40 years in age, that possess no architertural distinction or historical association. They have been documented photographically and by scaled plan drawings, but do not merit additional study prior to their destruction. 


\section{ACKNOWLEDGMENTS}

A number of individuals contributed to the successful completion of this project, and their assistance is gratefully acknowledged.

The staff of Fluor Engineers, Inc. provided technical support and guidance and demonstrated a commitment to high professional standards throughout the course of this study. The Texoma pipeline is under the overall supervision of Paul Johnson, Project Manager. Joe Zotter, Sr., Fluor's Environmental Manager, provided study management all necessary support in a timely fashion. Ed Janay served as Fluor's Contract Engineer.

Mr. Duke Rivet represented the Louisiana State Historic Preservation Office and provided valuable consultations during the background research and field investigations.

The Berger, Barnard \& Thomas staff was directed by John Hotopp, BB\&T's Principal Archaeologist. Charles LeeDecker was Principal Investigator and directed the field investigations. Claudia Holland served as Historical Archaeologist, conducted the laboratory analysis, and assisted with the field investigations. Field crew members were Charles Dunton, Michael Marchbank, Jeffery Huebner, and Bill Rosenberg. John Bukowski was logistics coordinator. Rob Tucher and Tony DiMasso processed and printed the photographs, and the drafting was completed by Gene Cass. Lee Nicoletti served as Report Production Coordinator, assisted by Michael Timpanaro, Production Assistant, and Suzanne Szanto, Technical Editor. 


\section{TABLE OF CONTENTS}

MANAGEMENT SUMMARY.

ACKNOWLEDGMENTS

TABLE OF CONTENTS.

ii

I. INTRODUCTION

II. ENVIRONMENTAL SETTING........................................... 7

III. BACKGROUND RESEARCH............................................ 9

A. Records Check......................................................... 9

B. Prehistoric Cultural Sequence...................................................... 9

C. Historic Development .................................................... 12

1. Research Methods....................................................... 12

2. Atakapa Ethnohistory............................................ 12

3. A Brief History of Cameron and Calcasieu Parishes........................ 13

D. Sensitivity Model......................................................... 15

IV. RESEARCH DESIGN................................................... 17

A. Problem Orientation........................................................ 17

B. Methodology ............................................................, 18

1. Field Methods......................................................... 18

2. Laboratory Methods............................................... 20

V. FIELD SURVEY RESULTS ............................................. 21

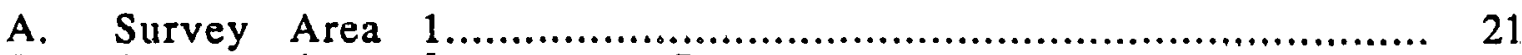

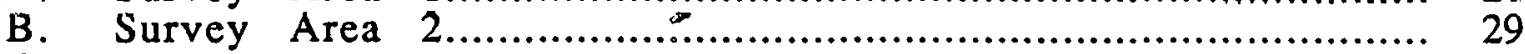

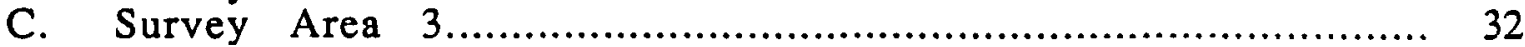

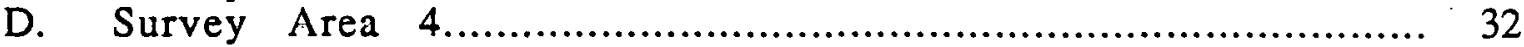

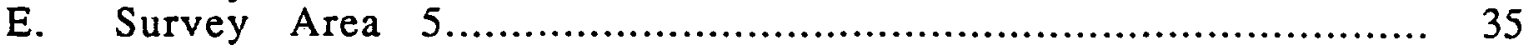

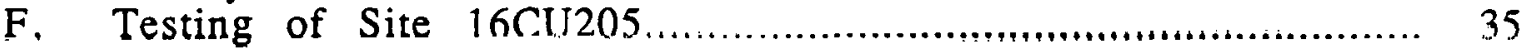

VI. DISCUSSION OF RESEARCH RESULTS........................................ 44

VII. RECOMMENDATIONS .................................................... 46

REFERENCES CITED .......................................................... 48 


\section{APPENDICES}

A: Shovel Test Table--Survey Transects........................................ A-1

B. Site Survey Forms.............................................................. B-1

C. Shovel Test Table--Site 16CU205.................................................. C-1

D. Artifact Catalog................................................................ D-1

E. Scope of Work................................................................. E-1

F. Staff Resumes.................................................................. F

\section{LIST OF FIGURES}

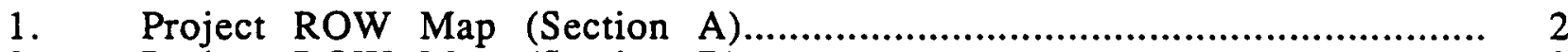

2. Project ROW Map (Section B) ........................................................ 3

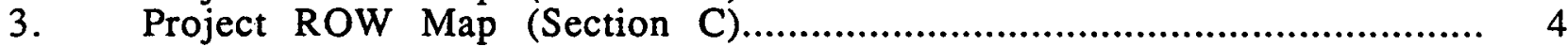

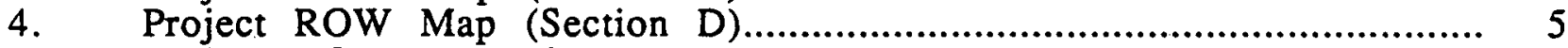

5. Project ROW Map (Section E) ..................................................... 6

6. Survey Area 1, Transects A, B, C, D, E, F, G, H, I and J......................... 22

7. Survey Area 1, Transects I, J, K and L......................................... 23

8. Survey Area 1, Transects $M$ and $N$ (northern section).................................. 24

9. Survey Area 1, Transects $\mathbf{M}$ and $\mathbf{N}$ (southern section)............................... 25

10. Survey Area 1, Transects P, Q, R and S.......................................... 26

11. Plan of Cow Barn, Survey Area 1, Tract 115...................................... 30

12. Survey Areas 2, 3 and 4, Transects A, B, C, D, E and F............................. 33

13. Survey Area 5, Transects $A$ and B..................................................... 36

14. Site 16CU205, Plan of Shovel Tests.............................................. 38

15. Artifact Distribution, Site 16CU205................................................. 40

\section{LIST OF TABLES}

1. Distribution of Artifacts by Class, Site 16CU205.................................... 41

2. Ceramic Inventory, Site 16CU205............................................. 42

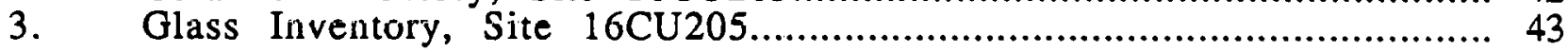

\section{LIST OF PLATES}

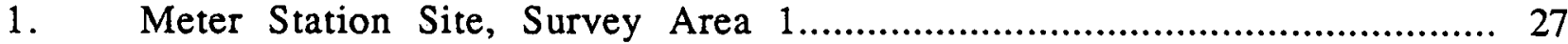

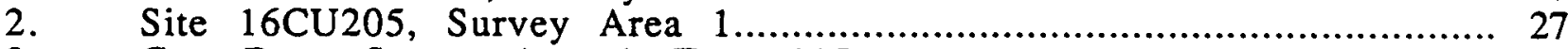

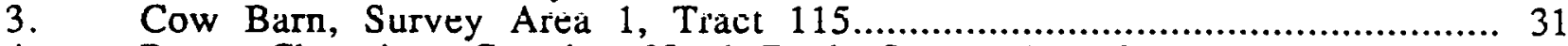

4. Bayou Choupique Crossing, North Bank, Survey Area 2......................... 31

5. Pipeline ROW Along Alkali Ditch, Survey Arca 4 ........................................ 34

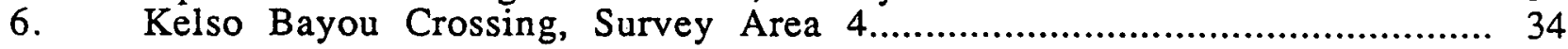




\section{INTRODUCTION}

A Level II Cultural Resource Investigation was undertaken for the proposed Texoma Distribution Enhancements Project, located in Cameron and Calcasieu Parishes, Louisiana. This study included background research, intensive field survey of the project area, evaluation of all cultural resources identified within the project area, and laboratory analysis of recovered artifact collections. The project was completed by the Cultural Resource Group of Berger, Barnard \& Thomas Engineering, Inc. (BB\&T) through a subcontract with Fluor Engineers, Inc. The lead Federal agency was the U. S. Department of Energy.

Since the proposed pipeline will be owned by the U.S. Department of Energy, this study was undertaken for compliance with Federal cultural resource management policies that require consideration of the effects on significant archaeological resources for Federal undertakings.

The proposed Texoma Distribution Enhancements Project will involve construction of a petroleum pipeline from Strategic Petroleum Reserve No. 3, located in West Hackberry, to a terminus located near Vincent Landing, Calcasieu Parish. The location of the project is indicated in Figures 1 through 5. The project area includes farmland, pastures, undeveloped woodland, residential areas, developed oil/gas fields, marshland, and several watercourses and drainage ditches. The overall length of the proposed pipeline is approximately 13 miles $(21 \mathrm{~km})$. The project area, termed the right-of-way (ROW), consists of the perpetual easement plus a temporary construction zone. Except at major crossings and facility sites, the ROW is 125 feet $(38 \mathrm{~m})$ wide, comprising of a 50 -foot $(15 \mathrm{~m})$ perpetual easement and a 75 -foot $(23 \mathrm{~m})$ temporary construction zone. The two major watercourses crossed by the ROW include the Gulf Intracoastal Waterway (GIWW) and Bayou Choupique. At these crossings, the ROW is up to 500 feet $(152 \mathrm{~m})$ wide, to provide sufficient area for required construction activities (see Figures 2 and 3). The total area included within the ROW is approximately 320 acres.

Following submission of a technical and price proposal in June 1987, the subcontract to BB\&T was awarded in July 1987 . Then a detailed field survey plan was prepared by BB\&T and submitted to the Louisiana SHPO for review. The field survey activities were initiated on July 28 and continued through August 5,1987. With the exception of one property, Tract 104, for which legal entry could not be gained, the entire ROW was surveyed during this period. Tract 104 was surveyed on August 21 , after legal access was gained. Laboratory processing of the recovered artifact collections was carried out during the period from August 6 to August 26, 1987.

All original field records have been submitted to Fluor Engineers, Inc., as required by the contract. Copies of the original field records have been retained by BB\&T. The recovered artifacts, along with copies of the field notes, will be submitted to the Division of Archaeology, Louisiana State Historic Preservation Office. 


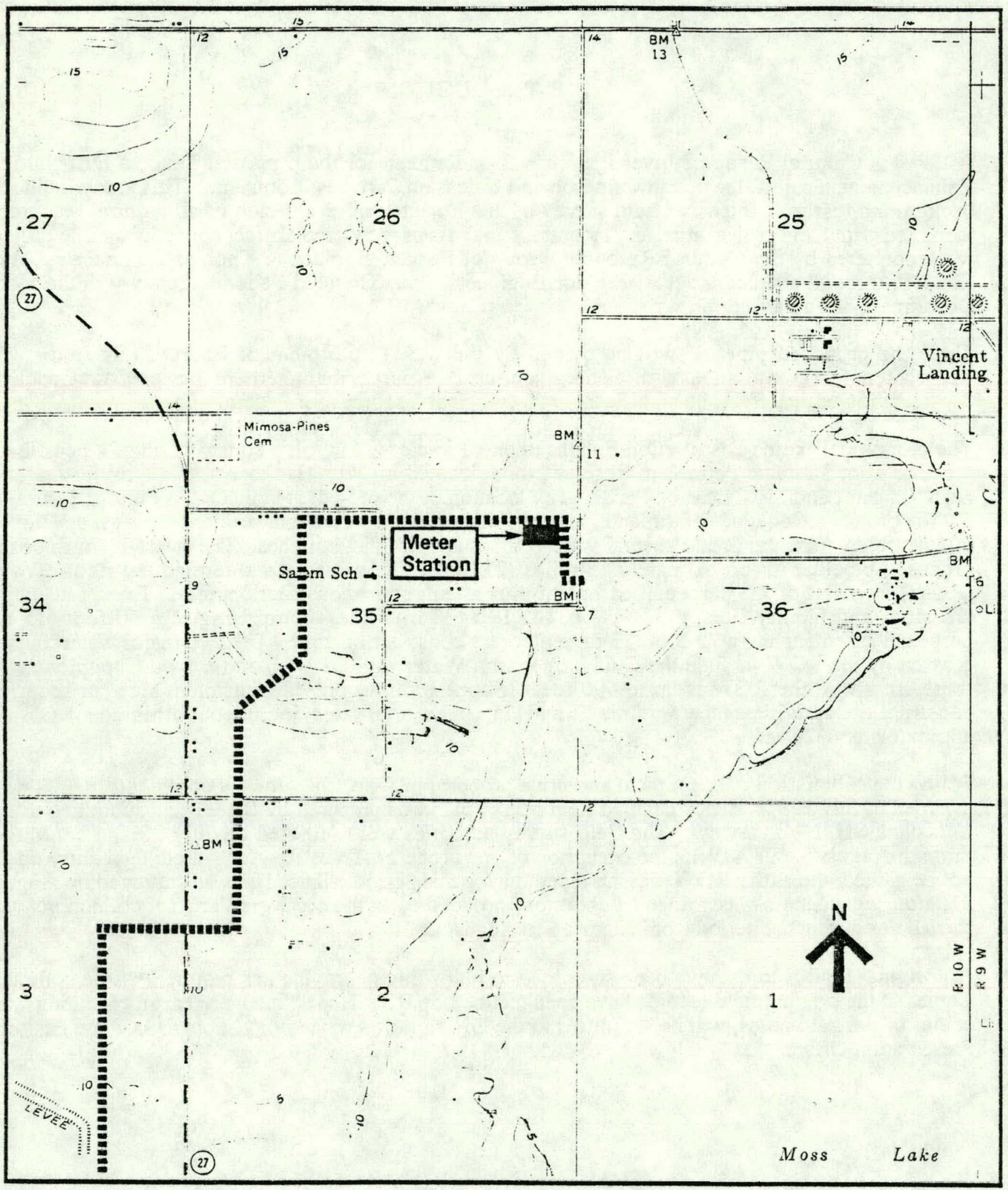

FIGURE 1. Project ROW Map (Section A). Source: West Lake, LA Quadrangle. Scale 1:24,000. 


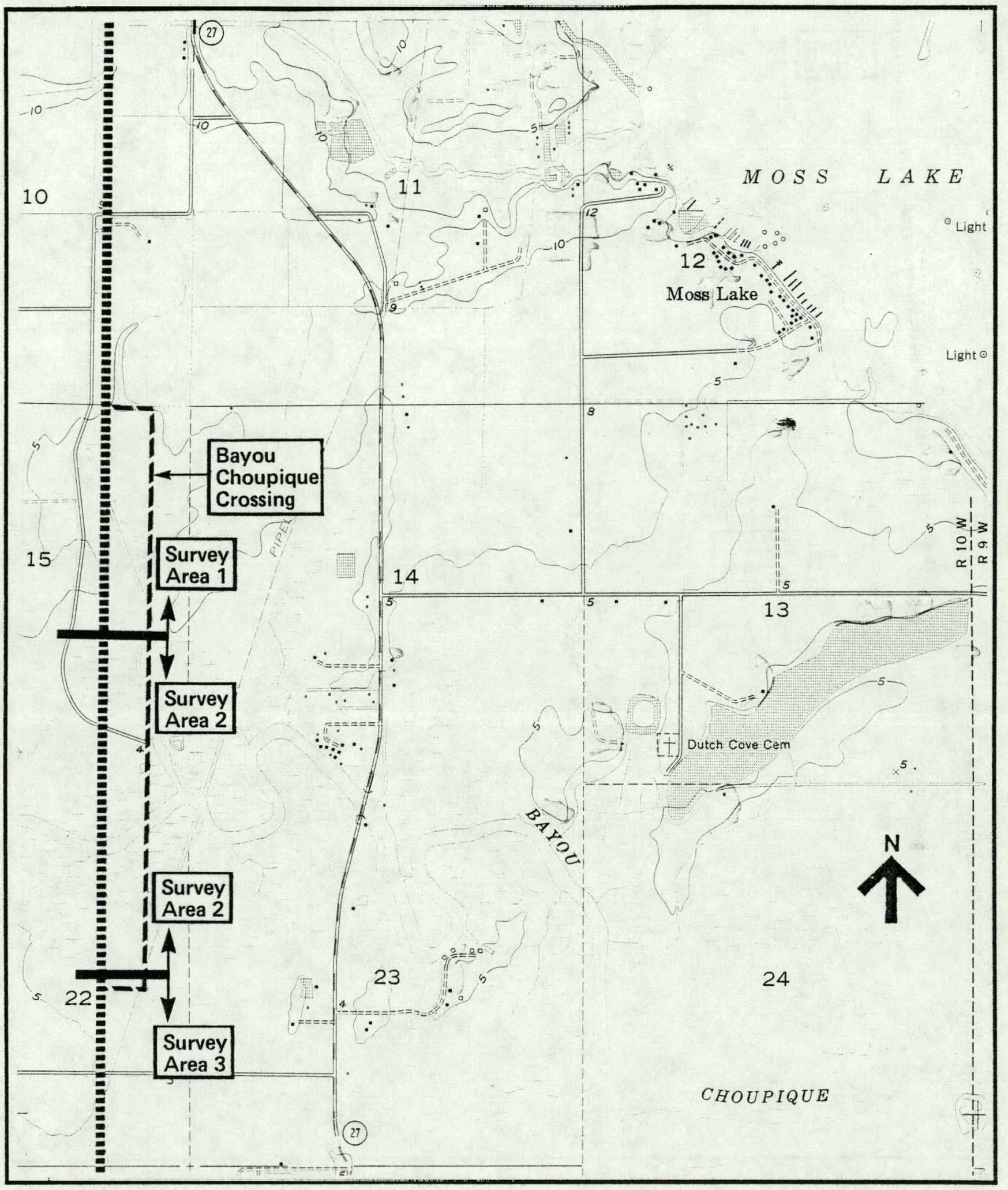

FIGURE 2. Project ROW Map (Section B). Source: Moss Lake, LA Quadrangle. Scale 1:24,000. 


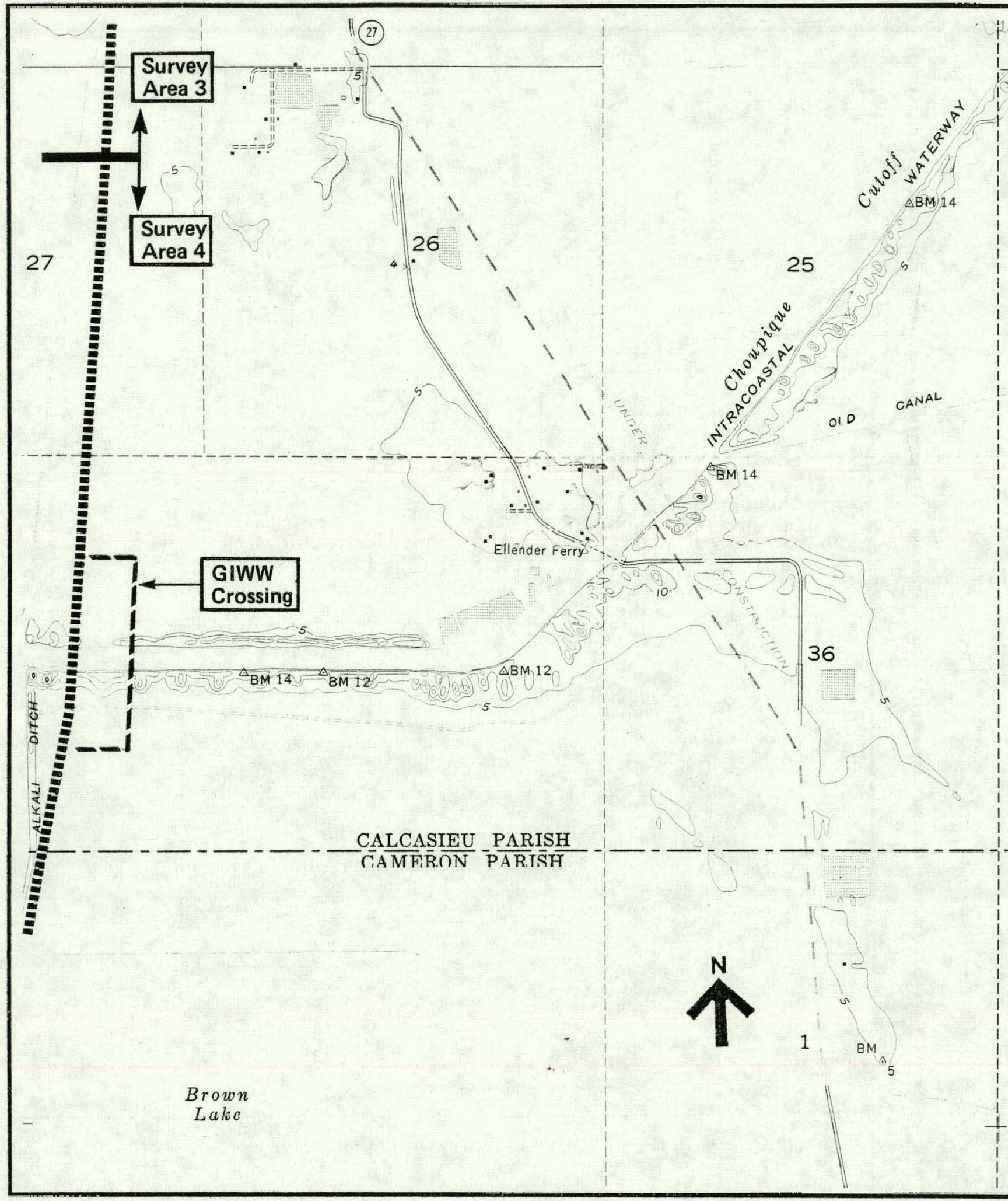

FIGURE 3. Project ROW Map (Section C). Source: Moss Lake, LA Quadrangle. Scale 1:24,000. 


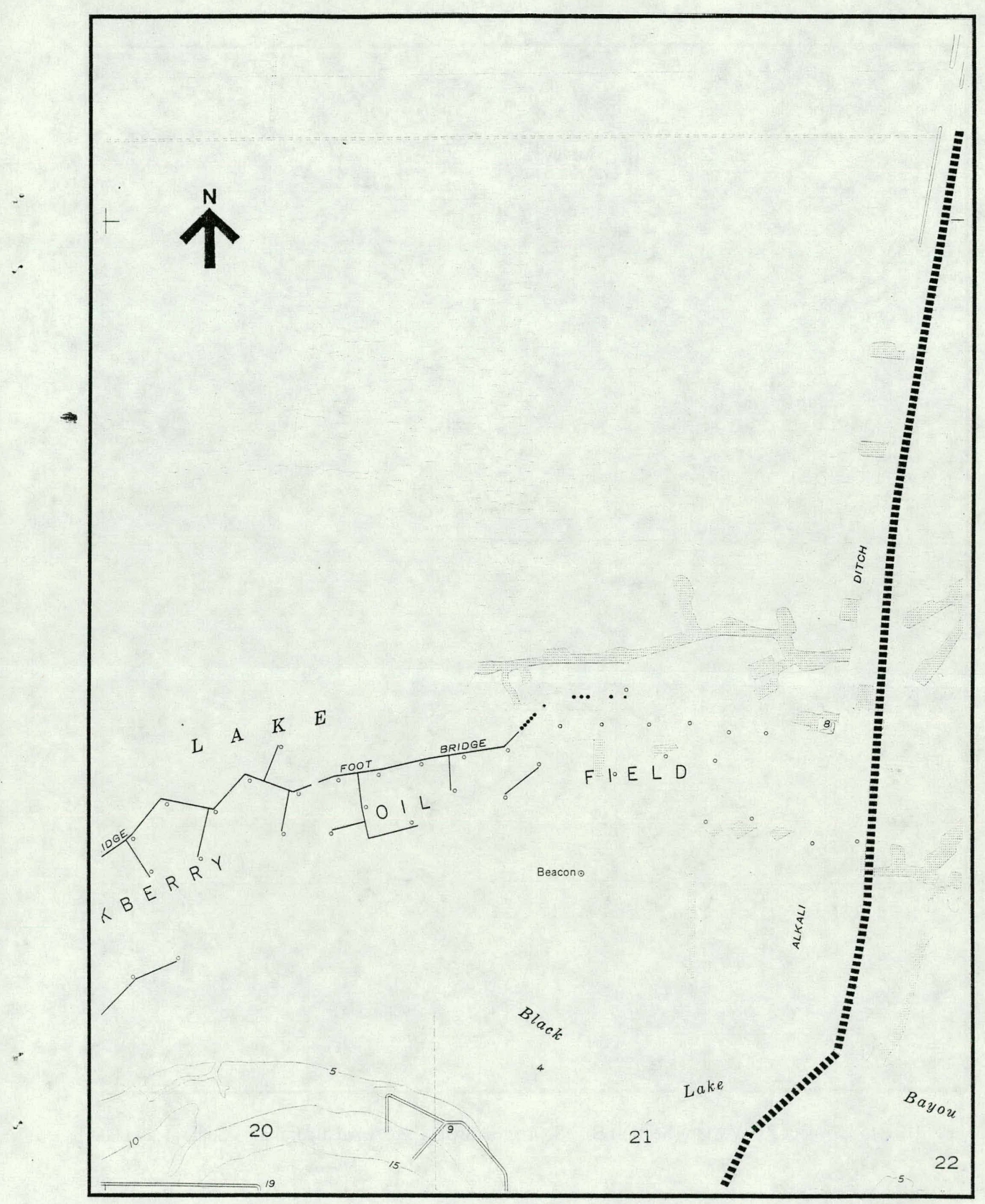

FIGURE 4. Project ROW Map (Section D). Source: Black Lake, LA Quadrangle. Scale 1:24,000.

5 


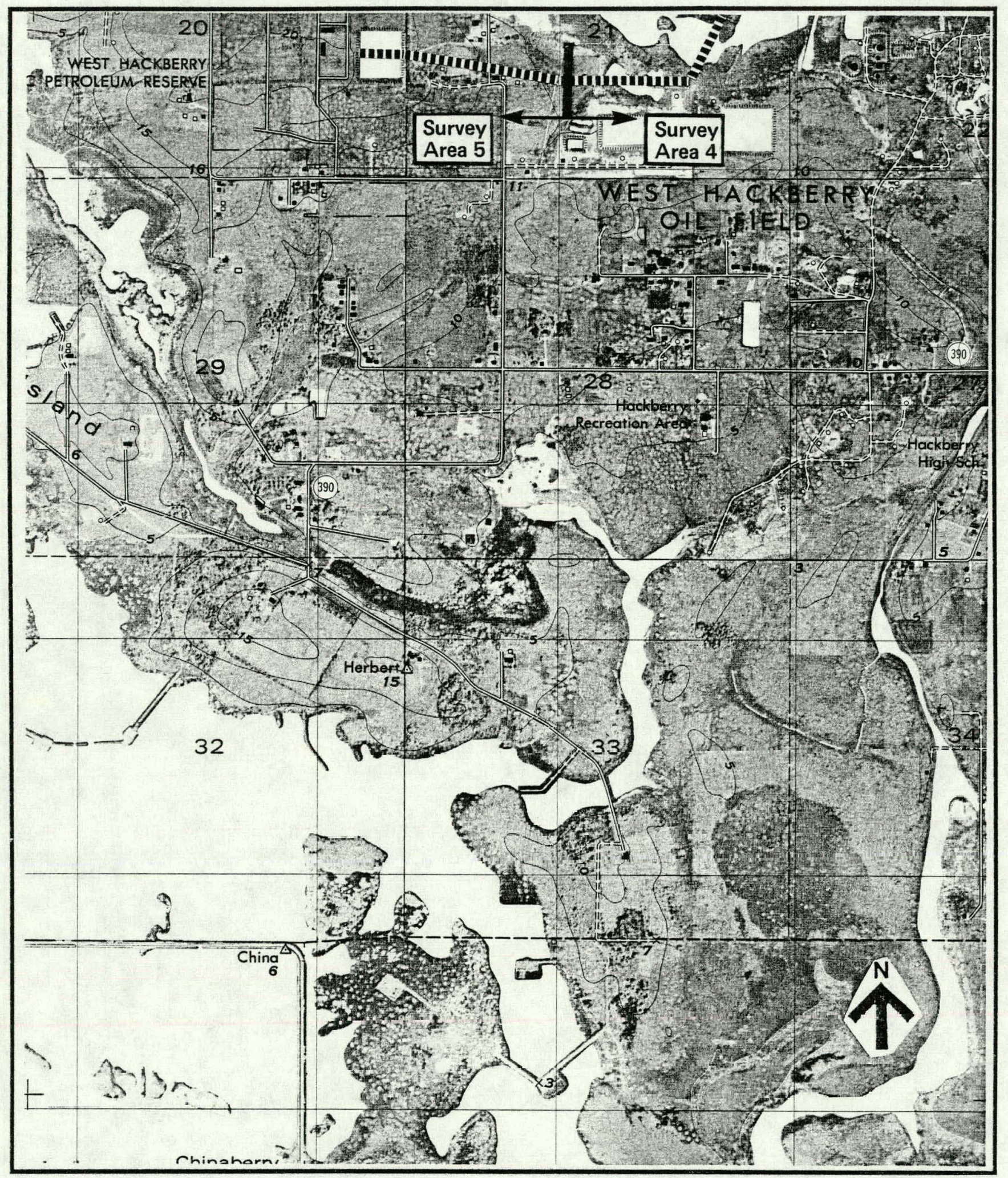

FIGURE 5. Project ROW Map (Section E). Source: Browns Lake, LA Quadrangle. Scale 1:24,000. 


\section{ENVIRONMENTAL SETTING}

Topography within the study area may be characterized as low and flat, with surface elevations ranging from sea level to approximately 20 to 25 feet above sea level. The highest land surface within the ROW is found at Hackberry Dome or Hackberry Island, presently the site of Strategic Petroleum Reserve No. 3, at the southern terminus of the ROW. The ROW traverses three major geological units: Pleistocene Prairie Terrace, Holocene Marsh Land, and Recent Alluvium.

Pleistocene Prairie Terrace comprises roughly the northern half of the ROW as well as the southern terminus of the project at Hackberry Island. In the northern portion of the project area, the Pleistocene Prairie Terrace is a relatively featureless plain with land surfaces that generally range from 5 to 10 feet above sea level. Pimple mounds are found throughout the Pleistocene Prairie Terrace, and they are the most conspicuous features of this geological unit. Pimple mounds are low, circular mounds, up to approximately 50 feet in diameter, that rise up to five feet above the surrounding terrain, although many have been leveled (Jones et al. 1954). Pimple mounds were observed most frequently in the extreme northern and southern portions of the ROW.

The most prominent active drainage feature in the northern Pleistocene Prairie Terrace area is Bayou Choupique, which empties into the Calcasieu River. In the ROW vicinity, Bayou Choupique is flanked by broad marsh areas formed in Recent Alluvium. The marsh areas adjacent to Bayou Choupique contain numerous disturbed areas, resulting from pipeline crossings, drainage ditches, and oil and gas exploration. The marsh area adjacent to Bayou Choupique is known as the Bayou Choupique Oil and Gas Field. The ROW also crosses a few minor unnamed bayous near the northern terminus of the ROW. These are readily identifiable on aerial photographs as natural drainageways; however, field inspection indicated that they appear to have been dredged to improve drainage.

The pipeline will traverse approximately six miles of Marsh Land, located in the southern portion of the project area. A few natural watercourses within the Marsh Land may be identified on aerial photographs, although the natural drainage system has been significantly altered by modern development. Near Hackberry Island, Kelso Bayou (also known as Black Lake Bayou) connected Black Lake and Calcasieu Lake, but extensive oil exploration activities around Hackberry Island have resulted in extensive modifications of this area's natural landscape. In particular, the lower reaches of Kelso Bayou have been subject to extensive drilling (Howe et al. 1935), and this area is known as the West Hackberry Oil Field. The Gulf Intracoastal Waterway (GIWW) is the most prominent drainage feature in the salt marsh area, but it is of minor interest in this study since it is a modern, man-made navigation channel. In the marsh land immediately north of the GIWW, relict channels or oxbows associated with an unnamed watercourse are visible on aerial photographs; however, it is uncertain if this was an active channel when the GIWW was constructed. Between Hackberry Island and the GIWW, the ROW runs roughly parallel to Alkali Ditch, another manmade drainage feature that extends through the marsh area.

There are no detailed soil maps available for either Cameron or Calcasieu Parishes. General soil maps (USDA 1969, 1971) indicate that the ROW crosses four major soils associations: (1) Mowata-Crowley, (2) Morey-Judice, (3) Harris-Salt Water or Bankers-Clovelly-Creole, and (4) Crowley-Morey-Mowata. The Mowata-Crowley soil association occupies the northernmost portion of the project area, which includes the most developed area of the ROW, and the Pleistocene Prairie Terrace south of Bayou Choupique. This association is characterized by nearly level to depressed silty soils with clayey subsoils. The Morey-Judice association corresponds to the Pleistocene Prairie Terrace area immediately north of Bayou Choupique; it is characterized by level to depressed dark 
colored soils that occur on broad flats. The Mowata-Crowley and the Morey-Judice associations are used primarily for pasture and some cultivated crops. The Harris-Crowley or Bankers-Clovelly-Creole association corresponds to the marsh areas; this association is characterized by mineral and salt water marsh soils that occur at or near sea level and are flooded by salt water, these areas are used mostly for wildlife habitat, but the more stable areas are suitable for cattle range. The Hackberry Island area at the southern terminus of the ROW is included in the Crowley-Morey-Mowata mapping unit. This association is generally characterized by nearly level silty soils with clayey and silty subsoils, and is suitable for some crops, primarily rice (USDA 1969, 1971). 


\section{BACKGROUND RESEARCH}

\section{A. Records Check}

Prior to the field survey, a review was made of the state site files and cultural resource management reports pertinent to the project area on file at the Louisiana Division of Archaeology. The archaeological site files indicate that numerous aboriginal sites have been recorded in the project area vicinity, but none are closer than one-half mile to the ROW. All of the previously recorded aboriginal sites in the immediate vicinity of the ROW are shell (Rangia cuneata) middens located along the banks of the principal watercourses (Calcasieu River and Bayou Choupique). Information provided on the site survey forms indicates that aboriginal occupation of the vicinity occurred during the Tchefuncte, Marksville, and Coles Creek periods.

The southwest Louisiana coastal area has not been studied as extensively as other areas of the state, but there have been a few prior archaeological studies that pertain to the ROW vicinity. The southern terminus of the ROW has already been subjected to a cultural resource survey by Coastal Environments, Inc. This study (Weinstein et al. 1979) involved an evaluation of the West Hackberry Strategic Oil-Storage Facility (Strategic Petroleum Reserve No. 3) and included the results of an earlier survey (Weinstein et al. 1977) as well. While no cultural resource sites were identified in the areas proposed for development, a number of sites were located in the surrounding area, including an aboriginal shell midden (Rangia cuneata) along Black Lake, designated 16CM87, and a number of historic house sites. None of these are within the proposed Texoma Pipeline ROW; however, the Ellender Home (16CM90) is located within one-quarter mile of the proposed ROW (see Figure 13). The Ellender Home was described by local informants as the main house of a nineteenth-century cotton and sugarcane plantation; however, no documentary research was undertaken to support this attribution (Weinstein et al, 1979).

An archaeological overview and survey was conducted for portions of the Gulf Intracoastal Waterway within coastal Louisiana by Coastal Environments, Inc. (Gagliano et al. 1975). This study provides a regional prehistory, history, and geology, together with a summary of known sites. Field survey included an evaluation of 315 miles of the waterway as well as selected spurs and spoil areas. While the GIWW traverses the project area currently under investigation, this portion of the GIWW was not subjected to field examination during the Coastal Environments, Inc. study.

The lower portion of Bayou Choupique was surveyed in conjunction with a proposed channel modification project, which extended east from Louisiana Highway 27 to the Gulf Intracoastal Waterway. Two aboriginal shell (Rangia cuneata) midden sites, both of which were located along the channel bank (Frank 1982), were identified during this project and have been designated 16CU181 and 16CU182. Neither site will be impacted by the proposed Texoma Pipeline ROW, since both are downstream from the Bayou Choupique crossing.

\section{B. Prehistoric Cultural Sequence}

The prehistoric resources of southern Louisiana have attracted the attention of archaeologists and antiquarians since the early nineteenth century. Most attention has been given to the ceramic cultures that flourished in the valleys of the Lower Mississippi and its major tributaries, however, and relatively little archaeological work has been done in the southwest Louisiana coastal area. While the ROW vicinity is somewhat marginal to the areas where the more advanced aboriginal cultures developed, it is expected that the general cultural sequence for the surrounding coastal region will be 
applicable to Cameron and Calcasieu Parishes. The major divisions of the cultural sequence for the Louisiana Coastal Region, with their beginning and ending dates, are as follows:

Cultural Period
Paleo-Indian
Early Archaic
Middle Archaic
Late Archaic
Poverty Point
Tchefuncte
Marksville
Troyville
Coles Creek
Plaquemine
Mississippian

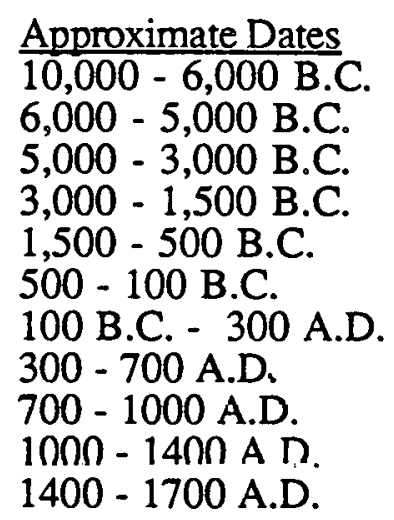

The Paleo-Indian Period (circa 10,000 B.C. to 6,000 B.C.) was characterized by a hunting and gathering subsistence pattern, followed by small nomadic bands. Large, fluted lanceolate projectile points are the distinctive artifacts of the early phase of this period, and a number of different projectile point styles evolved during the later phase. Hunting of now extinct megafauna was important in the Great Plains, and there is evidence that fauna such as mammoth, mastodon, dire wolf, giant ground sloth, giant bison, horse, tapir, and saber-toothed tiger existed contemporaneously with the early Paleoindian populations in the Southeast. With the climatic warming that accompanied the end of the last glaciation, smaller modern fauna, particularly deer, were intensively exploited. Paleoindian sites are infrequently found in coastal Louisiana, but are most often associated with major drainage features or salt domes (Gagliano et al. 1975; Neuman 1984).

Archaic Period (circa 6,000 B.C. to 1,500 B.C.) lifeways were characterized by hunting and gathering of a variety of food resources within a relatively well-defined territorial area. No sites were occupied on a permanent or year-round basis; rather, sites were occupied on a seasonal hasis. The. Archaic Period is commonly divided into Early, Middle, and Late sub-periods, although this period as a whole is poorly known in Louisiana, and the chronologies are based primarily on excavations from inland rockshelter sites with deep stratified deposits.

Very little is known of the Early Archaic lifeways in coastal Louisiana, although it may be assumed that a pattern of hunting and gathering was followed, oriented toward the changing environment that accompanied the glacial retreat. The Middle Archaic is also poorly known, and is perhaps most notable for the increased variety of tool types, particularly ground stone tools such as celts, grooved axes, and atlatl weights or bannerstones. The Late Archaic is marked by the appearance of more diverse artifact forms and by the increased inter-regional trade and mortuary ceremonialism, and higher levels of sociocultural integration. A seasonal hunting and gathering subsistence strategy continued during the Late Archaic, and exploitation of aquatic resources, particularly shellfish, may have become more important.

The end of the Archaic Period is marked by the development of the Poverty Point culture (circa 1,500 B.C. to 500 B.C.) in the Lower Mississippi Alluvial Valley. This culture is characterized by a chiefdom level of social organization, a widespread trade or exchange network, and a ceremonial center complex. Baked clay balls (Poverty Point objects), presumably used in cooking, are the 
principal diagnostic artifacts associated with Poverty Point components. Other cultural innovations include construction of massive earthworks, the use of steatite cooking vessels, a microlithic blade technology, the introduction of fiber-tempered pottery, a lapidary industry, and the production of copper ornaments (Webb 1977; Neuman 1984).

The Tchefuncte period (circa 500 B.C. to 100 B.C.) is represented in coastal Louisiana primarily by shell (Rangia cuneata) midden sites. In addition to mollusc, some of these middens contain well-preserved faunal and floral material, so that the subsistence pattern for this period is relatively well understood. Dietary remains associated with Tchefuncte midden sites include deer, bear, muskrat, opossum, otter, gray fox, ocelot, alligator, catfish, alligator gar, drum, hickory nut, acorn, plum, grape, persimmon, squash, and bottle gourd. In the coastal areas of Louisiana, sites from this period are most frequently located on elevated topographic features such as cheniers, salt domes, and natural levees. Human burials have also been recovered from Tchefuncte shell middens, so that some information is available concerning the physical characteristics and burial customs for Tchefuncte populations. In terms of subsistence and settlement pattern, the Tchefuncte period seems to represent a continuation of Late Archaic lifeways, and it differs primarily by the addition of a well-developed ceramic complex. Tchefuncte vessel forms include various bowls and pots with constricted necks, with various decorations that include punctations, incising, stamping, pinching, notching, cord impressing, and brushing (Neuman 1984:113-136; Gagliano et al. 1975).

The Marksville period (circa 100 B.C. to 300 A.D.) is defined primarily on the basis of Hopewellian culture. Hopewell cultures developed in the Ohio and Illinois River valleys, and most of the Mississippi Alluvial Valley cultures were involved to some extent in the "Hopewell Interaction Sphere" which was characterized by widespread trade in exotic raw materials and diffusion of elaborate mortuary ceremonialism. The period is notable for the construction of conical burial mounds that often contain human burials and associated grave goods. Previous excavations have focused on the more spectacular mound sites, which in Louisiana are concentrated in the Red River Valley. In the coastal areas, Marksville components are most often located on cheniers and natural levees. While horticulture may have gained importance during this period, there is only very limited evidence for the use of cultigens such as maize. Marksville ceramics include bowls, beakers, and hemispherical pots decorated with various distinctive motifs that appear to have diffused from the Illinois Hopewell cultures. As a whole, the Marksville ceramic complex seems to exhibit a strong continuity with the preceding Tchefuncte ceramic industry, but with the addition of a greater variety of vessel forms and decorative motifs and techniques (Toth 1979; Neuman 1984: 137-168; Smith et al. 1983:171-180).

The Troyville (circa 300 A.D. to 700 A.D.) and Coles Creek (circa 700-1000 A.D.) periods are characterized by the development of ceremonial centers that contained rectangular, flat-topped mounds that were often arranged around an open plaza. These sites are relatively common in the inland areas of Louisiana, and they are most frequently found on natural levees along major watercourses. The increased number of sites of this period indicates a period of population growth and stability, possibly achieved by the greater use of cultigens such as maize. Aside from the large village sites that include one or more ceremonial mounds, Troyville-Coles Creek components have been identified at a number of shell midden sites in coastal Louisiana. These sites are most frequently located along remnant Pleistocene terraces or natural levees which would have afforded some protection from flooding. The middens contain primarily Rangia cuneata, with an admixture of other mollusc species and other fauna including deer, bear, beaver, skunk, muskrat, raccoon, alligator, turtle, bowfin, catfish, drum, gar, etc. Human interments are also occasionally found within the midden deposits. In Cameron Parish, the Pierre Clement Site (16CM47) was partially excavated as part of an overall study of Troyville-Coles Creek manifestations in coastal Louisiana. The site was 
located on a chenier approximately nine miles from the Gulf Coast and consisted primarily of Rangia cuneata, but also included a variety of mammal, waterfowl, and fish as well as human burials (Neuman 1984:169-214).

Plaquemine occupations are found throughout coastal Louisiana, and this period (circa 1000 to 1400 A.D.) is generally seen as a continuation of the preceding Troyville-Coles Creek cultural pattem. Plaquemine occupations are distinguished archaeologically by a distinctive ceramic industry and a greater variety of mortuary practices, and there is evidence for increased reliance on cultigens, particularly maize, beans, and squash during this period. In many areas of coastal Louisiana, Plaquemine culture persisted to the protohistoric period, and there is little evidence that the populations in the southwest coastal region participated in the developments of the Mississippian culture (circa 1400 to 1700 A.D.). The Mississippian culture developed in the Middle Mississippi Valley and was characterized by an economy based on intensive agriculture and hierarchical sociopolitical organization. Populations bectame more concentrated and large, fortified villages were constructed that included temple mounds and specialized craft areas (Neuman 1984:272-283; Smith et al. 1983:203-210).

\section{Historic Development}

\section{Research Methods}

Historical background research was conducted both prior to and during the fieldwork phase of this project. Historic maps were of primary interest because of the need to identify potential site areas within the proposed pipeline ROW. Maps at the Louisiana State University, Cartographic Information Center, Baton Rouge; Louisiana State Land Office, Baton Rouge; and McNeese University Archives, Lake Charles, were examined in an attempt to pinpoint settlements or homesteads in the vicinity of, if not within, the ROW. Additional information from primary and secondary sources was sought at the Special Collections section of the Louisiana State University Libraries, Baton Rouge; Calcasieu Parish Courthouse, Lake Charles; Imperial Calcasieu Historical Society, Lake Charles; two private land title companies (Mayo and Levingston) in Lake Charles; Lake Charles Public Library; McNeese University Archives, Lake Charles; and the Louisiana State Archives, Baton Rouge.

\section{Atakapa Ethnohistory}

Cabeza de Vaca, treasurer of Panfilo de Narvaez's ill-fated expedition to Florida, provided the earliest description of Texas coastal Indians related to the Atakapa of southwestern Louisiana. These Indians called themselves "Ishak" or "the people," whereas the name "A takapa," of Choctaw or Mobilian origin, means "eater of human flesh" (Kniffen et al. 1987:44). Their reputed anthropophagous habits, however, were limited to the eating of portions of slain enemies rather than indiscriminate cannabilism.

The Atakapa occupied what is presently southwestem Louisiana, from upper Bayou Teche to the Sabine River and from the Gulf of Mexico northward almost to Alexandria. Comprising four sovereign bands, the eastern Atakapa bands lived on upper Bayou Teche, on lower Vermilion River, near Plaquemine Brule, near Lake Arthur on the Mermentau River, on western Grand Lake, on lower Bayou Nezpique, on Bayou Queue de Tortue, and on Lacassine Island. The two western bands occupied the banks of the Calcasieu River and the lakes around Lake Charles (Kniffen et al. 1987:46). Large areas remained unoccupied by the Atakapa, who customarily chose to settle along major water bodies. 
Atakapa material culture was relatively meager compared with other southeastern Indian groups. As a result, they offered little of trade value to French factors who established trading posts near Indians who could provide them with furs and other lucrative commodities. Bienville reported in 1733 that the Atakapa had come to New Orleans to request men to come to their country to trade, but little interest was shown because they did not live in permanent settlements (Post 1962b:224-225). The mobility of the Atakapa was exemplified by their pole and mat covered houses, which could be "disassembled and hauled to another site" (Kniffen et al. 1987:114-115).

Leading a largely nomadic life, the Atakapa seasonally exploited the marsh and prairie resources which provided them an unlimited amount of fish, shellfish, and small game. Molluscs such as freshwater mussels (Unio), brackish water clams (Rangia), and saltwater species including oysters (Ostrea) were readily available by short boat trips (Kniffen et al. 1987:20). Waterfowl, otter, mink, deer, and to some extent bison were hunted for food and fur. Hunting practices included the use of fire to bring game into the open in addition to running deer to exhaustion as a means of capturing the animals. Agriculture and hunting large game were of minor importance to the Atakapa.

The Atakapa remained relatively isolated through the eighteenth century. Their lands were protected from white intrusion by a natural barrier, the Atchafalaya Basin. Moreover, their location away from the main French highway during the colonial period (1699-1762) afforded them some protection from molestation (Post 1962b:224). Lands between Bayou Teche and the Vermilion River, however, were eventually sold to French settlers. During the American Revolution, the Atakapa furnished Galvez, the Spanish governor of Louisiana, with 180 warriors from two bands to fight against the British forts along the Mississippi River (Post 1962b:229). After the Louisiana Purchase, the Atakapa were one of only four resident Louisiana tribes who had survived in any numbers. Swanton (1979) estimated that the population of Atakapa Indians and their allies for Southwest Louisiana and Southeast Texas in 1698 was about 3500, with around 1750 in Louisiana. This number had dropped to 175 by 1805 (Post 1962b:232). Undoubtedly, disease, starvation, assimilation, and more contributed to the demise of the Atakapa. Inhabited in the early twentieth century, the last Atakapa village was on Indian Lake, now called Lake Prien, in Calcasieu Parish (Kniffen et al. 1987:46).

\section{A Brief History of Cameron and Calcasieu Parishes}

The following is a general discussion of the history of Louisiana's Calcasieu and Cameron parishes, focusing on the western sections of each. This geographical focus stems from the location of the proposed Texoma Pipeline project and its vicinity.

Much of southwestern Louisiana was sparsely populated until the late eighteenth and early nineteenth centuries. Spanish explorers had claimed the Gulf coastal area för the king of Spain, but little effort was made to colonize the region. Subsequent French control of the Louisiana Territory resulted in minimal advances in populating the colony, especially in the southwestern area. Atakapa lands were designated as part of the Orleans District, one of seven districts established by the French government in 1723. Although easily accessible through a system of navigable waterways, this territory was seldom visited by the French district officers. It was largely inhabited by the Atakapa Indians and a few white trappers and hunters (Perrin 1971:14-15).

Following the transfer of Louisiana to Spanish jurisdiction by a secret treaty in 1762 , several military posts were established in the various districts of the province. The Poste des Attakapas, presently known as St. Martinville, was built on Bayou Teche in the mid-1700s. It served as the administrative center from which civil and military concerns of the district were managed. Lands were subsequently parceled out or surveyed by Spanish officials and "granted to the families in quantities to be 
determined according to their means" (Perrin 1971:16). This policy encouraged the settlement of southwestern Louisiana by Germans, Spanish immigrants from the Canary Islands, and Acadian refugees from British Novia Scotia, to name a few.

The land lying between the Sabine River and the Calcasieu River, formerly known as the Rio Hondo, was a disputed territory claimed by both the United States and Mexico. Pioneers settling on the east side of the Calcasieu between 1780 and 1819 acquired their property from the Indians or homesteaded "Rio Hondo" claims until the lands officially became United States property (Calhoun 1984:191). Nevertheless, settlements gradually became established along the Calcasieu River as early as 1815. Although at one time "the largest in territory, [Calcasieu Parish] was the last opened to settlement" (Perrin 1971:126).

Calcasieu Parish was organized in 1840 and the town of Marion designated the parish seat. Marion, also known as Old Town, was originally a resting place for drovers moving their cattle from Texas to market in New Orleans. Italian Charles Sallier, for whom the city of Lake Charles is named, settled near the mouth of the Calcasieu River in the 1820s. This city, the largest in the parish, eventually became the parish seat and was an important center for the timber industry as well as a rapidly growing port. More recently oil and related industries and chemical and petrochemical plants have become the leading commerce of the city (Calhoun 1984:192).

Calcasieu Parish contains piney woods to the north and marshy wetlands to the south, separated by grass prairies. Rice, corn, cotton, sweet potatoes, sugar cane, and various garden vegetables have been successfully grown in the area, with rice and cane particularly lucrative to the enterprising farmer. Fruit and citrus crops have also been raised with moderate success (Perrin 1971:131-138). Perhaps the most profitable economic endeavors were and continue to be rice cultivation, the harvesting of yellow pine and cypress, and the extraction of oil and, formerly, sulphur (Ellender n.d.:4-6). A large sulphur deposit was discovered near the present city of Sulphur in the late 1860s. "One of the world's largest sulphur industries was established at the site and flourished until the late 1920s" (Calhoun 1984:191). About this time, deep well drilling techniques became known, and the oil industry was developed. A spin-off of the lumber industry was the development of the naval stores or turpentine industry. The excellent yellow pine in Calcasieu Parish provided products from both timber and sap for domestic and intematinnal markets (Ulmer 1935:53).

Another profitable venture in this parish has been stock raising. Cattle and horses were originally brought into Mexico by the Spanish, who traveled northward and into Texas on their entradas with vast herds of livestock. Colonists in Louisiana, particularly the Acadians, obtained their cattle from the Spaniards. By the third quarter of the eighteenth century much of central and southern Louisiana had become an important herding region (Post 1962a:40). Settlement in the eastern prairies was followed by a westward movement across the prairies. Cattle were allowed to range freely part of the year, although branding was required as a means of claiming one's stock. In fact, the Atakapa owned enough cattle to make the effort to pay the fee to register their brands in St. Martinville (Post 1962b:234), Agriculture to some extent replaced stock raising in southwestern Louisiana, and the prairie landscape became dominated by the cultivation of rice.

Cameron Parish, the largest in land area in the state, was created from parts of Calcasieu and Vermilion parishes in 1870 . Like Calcasieu, however, its early history is derived from that of several large southwestern parishes such as St. Landry. Early settlement occurred prior to the 1850s, although the population was relatively sparse. The parish seat is presently the town of Cameron, but originally it was Leesburg (Perrin 1971:171-172). 
Cameron is largely a region of wetlands with but a small area of prairie to the north and the cheniere plains to the south. The abundant game and coastal resources-fish, crustaceans, and molluscs-attracted the hunter, trapper, and fisherman alike. Cotton, corn, melons, and citrus, particularly orange, and fruit trees have been grown successfully, but rice, corn, and vegetables are presently the predominant crops. Oil and related industries and menhaden companies have more recently concentrated in Cameron Parish due to the discovery and collection of these resources (Calhoun 1984:193-194).

The enormous orange crops that were formerly raised in lower Cameron were destroyed by hurricanes that beat the coast in 1886 and 1918 and, since 1915 , by gradually colder temperatures killing off the citrus (Hollister 1952). Agriculture has been nominally replaced by cattle raising and the creation of game refuges, which encompass 25 percent of the parish. Nutria, a relatively recent immigrant to the marshes, has become the backbone of the fur industry in Cameron Parish.

\section{Sensitivity Model}

The predicted archaeological sensitivity of the project area was defined prior to the field survey, on the basis of the background research, together with a consideration of the environmental characteristics of the ROW.

Virtually all of the previously recorded prehistoric sites in the ROW vicinity are shell middens, and they are located exclusively along the banks of natural watercourses (Calcasieu River, Bayou Choupique, and Black Lake). Given this distributional pattern for previously recorded sites in the ROW vicinity, all intact natural channel margins were considered to be high probability areas for prehistoric sites. Specific channel bank locations within the ROW that were predicted to have high sensitivity for aboriginal sites include: (1) the margins of Bayou Choupique, (2) the margins of minor unnamed sloughs or bayous on the Pleistocene Prairie Terrace at the north end of the ROW, and (3) the margins of natural drainages within the salt marsh area.

While the channels of Bayou Choupique and the minor unnamed bayous in the Prairie Terrace appeared to be relatively undisturbed on recent aerial photographs and modem maps, there has been extensive disturbance to the Marsh Land between Hackberry Island and Bayou Choupique. Oil and gas exploration, and construction of Alkali Ditch and the Gulf Intracoastal Waterway (GIWW) have severely altered the Marsh Land area, but there is some evidence that intact stream channels may not have been destroyed. The southern portion of the marsh land is drained by Kelso Bayou (also known as Black Lake Bayou) and this area appears to have been extensively disturbed by oil exploration (see Figure 4). However, comparison of the modern quadrangle with a map of Kelso Bayou prepared in the early twentieth century (Howe et al. 1935:Plate 4) suggests that oil exploration and other development may not have damaged the crossing of Kelso Bayou to an extent that would have totally destroyed an aboriginal shell midden. The northern portion of the marsh land also has been severely disturbed by construction of the GIWW. However, recent aerial photographs show a possible stream channel in the area immediately north of the GIWW, so that this area was also considered as a high probability area for prehistoric sites, particularly if intact natural levees or high banks were present along the channel.

Prior studies in coastal Louisiana have demonstrated that aboriginal sites are often associated with topographic features such as salt domes, natural levees, cheniers, or remnant terraces. The ROW does include a portion of a salt dome, at Hackberry Island; therefore this portion of the ROW was defined as a high probability area for prehistoric sites. There are no cheniers within the project area, as these features are found closer to the present coastline. Natural levees and remnant terraces may be 
present, but they cannot be identified on the basis of available topographic maps or aerial photographs. There is some evidence that pimple mounds were selected as preferred habitation areas by aboriginal populations (Bonner 1972), and these features are plainly visible throughout the ROW vicinity, particularly within the Pleistocene Prairie Terrace portions of the project area.

Since the ROW vicinity was marginal to the areas of initial European and American settlement, it was expected that most historic resources in the area would date to the modern period, that is, late nineteenth and twentieth centuries. Specific sensitivity areas for historic period sites were identified using cartographic materials available in the Special Collections of the Louisiana State University Libraries; the Cartographic Information Center of the Department of Geography and Anthropology, Louisiana State University; and the state site files of the Louisiana Division of Archaeology. Based on these sources, three areas in the project ROW were defined to have high potential for historic resources. In the northern portion of the ROW, two structures are visible on the 1932 West Lake quadrangle map (USGS 1932), located to the north and south of State Rt. 1133. It is most likely that these represent domestic sites or possibly farmsteads. Other types of historic sites that might be present in the ROW but which are not identified during the cartographic review include turpentine or logging camps and homesteads. Due to the low topography and, consequently, wet condition of most of the land south of Bayou Choupique, it was considered unlikely that this locality was inhabited to any great extent by historic peoples. However, the potential for occupation increases as higher ground (i.e., 5 to 10 feet above sea level) with better drained soils becomes present, so that the Hackberry Island area was also identified as an area of potential historic occupation. The Ellender Home (16CM90) has been recorded on Hackberry Island, approximately 400 feet $(120 \mathrm{~m})$ south of the ROW (see Figure 13). This site is described on the site form as the main house of an antebellum plantation, and it is possible that outbuildings associated with this site might be identified within the ROW. 


\section{RESEARCH DESIGN}

\section{A. Problem Orientation}

Perhaps the most significant development in cultural resource management (CRM) studies in the past several years is the increased attention given to the development and explicit use of research designs. While the proposed Federal guidelines "Recovery of Scientific, Prehistoric, Historic and Archaeological Data: Methods, Standards and Reporting Requirements" (36 CFR 66) recommend the use of research designs for all cultural resource management projects, the use of research designs has been somewhat neglected, particularly on small survey projects. This state of affairs in the CRM profession has been pointed out periodically by various investigators, and CRM practitioners have been urged to develop regional models that are amenable to testing on small survey and evaluation projects. It has also been argued that valid assessments of cultural resource significance must be carried out with respect to preservation planning priorities that are based on local and regional cultural models (Goodyear et al. 1978; Raab and Klinger 1977).

The kinds of research problems that may be addressed during a particular CRM project depend on a project's scope of work and on the state of knowledge of the particular project area vicinity. The primary CRM objectives of the proposed study are:

1) identify all cultural resources that may be affected by the proposed project;

2) evaluate the significance or National Register eligibility of all cultural resources within the project area;

3) determine what effect the proposed project will have on the resources identified in the project area;

4) develop strategies for mitigation of adverse effects for significant resources that will be affected by the proposed project.

In addition to these basic management needs, a number of additional research questions were posed to guide the program of investigations. These questions were developed after preliminary background research indicated that there has been relatively little previous archaeological work in the southwest Louisiana region, and that the area's prehistoric and historic cultural development is known only in very general outline. Because the scope of work emphasizes site identification and evaluation, rather than intensive data recovery, the types of research questions appropriate to this study focus on settlement patterning, local cultural chronology, and patterns of resource exploitation. In general, these research questions correspond to the information needs identified for southwest Louisiana that have been identified in Louisiana's Comprehensive Archaeological Plan (Smith et al. 1983). Stated explicitly, the research questions for this study are as follows:

1) What is the overall distribution of prehistoric sites in the project area and surrounding vicinity?

2) Are there any apparent differences in the settlement pattern during the various periods of prehistoric occupation? 
3) What types of natural resources were exploited in the study area during the various periods of prehistoric occupation?

4) Do the prehistoric sites in the study area exhibit emphasis on expoitation of seasonally available resources, or is there evidence of year-round habitation?

5) How have the archaeological resources in the study area been affected by various historic land uses--agriculture, dredging of waterways, and residential, commercial, and industrial development?

6) What is the nature of the earliest historic occupation, i.e., where are the initial historic occupations located and what was the economic basis for the region's initial settlement?

These questions were developed in BB\&T's original technical proposal, prior to the actual field survey, and they were used to provide general guidance to the required background research, field survey and testing, and laboratory analyses. Because they presuppose that archaeological resources representative of the area's prehistory and history would be identified within the project area, the applicability of the present project for addressing these questions is necessarily dependent on whether or not various types of archaeological properties exist within the project area.

B. Methodology

\section{Field Methods}

Since the first objective of the investigation was to provide an inventory of cultural resources within the project area, the principal field methodology involved a visual inspection, supplemented by systematic subsurface testing, of the ROW. Since the project area is essentially a linear corridor, a pedestrian survey was accomplished by the field personnel walking transects parallel to the proposed pipeline centerline. Within the areas of 125-foot $(38-\mathrm{m}) \mathrm{ROW}$, two transects were established approximately 37.5 feet $(11.5 \mathrm{~m})$ from the lateral ROW boundaries and 50 feet $(15 \mathrm{~m})$ apart, thereby allowing complete visual coverage of the ROW. The field survey was accomplished by a crew of four archaeologists, organized into teams of two persons, with each two-person team working along a single transect.

To facilitate management and reporting, five major survey areas were defined along the ROW, which correspond to the major environmental zones. These were designated as follows:

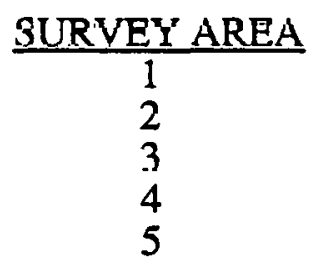
ENVIRUNMENTAL ZONE
Pleistocene Prairie Terrace north of Bayou Choupique
Recent Alluvium along Bayou Choupique
Fleistocene Priuire Terracc south of Bayúu Choupique
Salt Marsh
Pleistocene Prairie Terrace at Hackberry Island

These survey area designations were referenced in the field records, in addition to specific transects, shovel tests, and real estate tract numbers. Transects were designated alphabetically, beginning with the letter "A." New transect designations were assigned when the ROW changed direction (e.g., 
from north-south to east-west) or at road crossings within a long stretch where the ROW did not change directions. The sequence of transect designations was also started when a new survey area was entered.

During the walkover survey, a visual inspection was made for artifact scatters, structural remains and landscape anomalies that might be indicative of cultural activities. Since the majority of the ROW was in pasture, marsh, and woodland, areas of bare ground exposure were relatively infrequent. Eroded areas and cut bank exposures along streams and drainage ditches were inspected as they presented themselves in the field, but the majority of the ROW was characterized by vegetative cover that reduced the value of surface inspection alone as an effective survey methodology.

Because of generally poor ground visibility throughout the ROW, shovel tests were placed along the walkover transects. Shovel tests were placed at varying intervals along the transects, depending on the predicted archaeological sensitivity of the particular area. (Prior to the field survey, a sensitivity model was developed for the ROW, based on the results of the background research; this is discussed in Section III.D above.) Within areas of predicted sensitivity, shovel tests were placed at 82-foot (25-m) intervals; in the remaining areas, shovel tests were placed at 262 -foot $(80-\mathrm{m})$ intervals. The intervals between shovel tests were occasionally varied to allow placement of shovel tests according to microtopographic features such as pimple mounds or stream banks. Shovel tests were numbered sequentially along each transect.

Since the ROW centerline had been staked in most areas, following the alignment was relatively simple, except in situations where the centerline stakes had been obscured by vegetation or knocked down by cattle. In these areas, orientation was accomplished with a compass. Distances between transects and between shovel tests were estimated with calibrated paces.

Shovel tests were circular holes, approximately one foot $(30 \mathrm{~cm})$ in diameter, excavated with spades and trowels. Shovel tests were excavated in natural soil levels to a minimum depth of 12 inches (30 $\mathrm{cm})$. Excavated soils were screened through 1/4-inch hardware cloth screens, except in situations were the soils had a high clay content; in these situations, the spoil was troweled. For each shovel test, a schematic soil profile was recorded, including Munsell soil color notation and standard USDA soil textural classes for each soil layer or stratum. All shovel tests were backfilled immediately upon completion of the unit profile.

While the entire ROW was subject to visual inspection, it was not possible to perform a walkover survey or shovel testing within the marsh areas. Extensive marsh areas occur in the southern portion of the project area and along Bayou Choupique. Since these areas were inaccessible for pedestrian survey, a boat was utilized to conduct a cutbank survey and to search for isolated islands of high ground that might have supported prehistoric or historic occupation. Other inaccessible marsh areas were identified throughout the remainder of the ROW, but these were generally small enough that they could be circumvented during the walkover survey.

Site evaluation procedures were oriented toward determination of each site's horizontal and vertical boundaries, assessment of integrity, and recovery of a sample of material sufficient to determine the site's period of occupation and function. Generally, this involved more intensive shovel testing around the original find spot according to a grid system. Since the contract did not provide for any testing outside the ROW limits, it was impossible in one situation to determine the site's horizontal boundaries. 
Although no buildings more than 40 years old were identified during the survey, all standing architectural sites within the ROW were documented photographically and by scaled plan drawings.

Other aspects of the project recordation included black-and-white and color slide photography of the general field conditions, including all areas that were not surveyed because of intensive disturbance.

\section{Laboratory Methods}

Following completion of the field survey, the artifacts were taken to the BB\&T laboratory in Baton Rouge, Louisiana. The artifacts were then cleaned, cataloged, analyzed, and prepared for permanent curation. State archaeological site survey forms were prepared and submitted to the Louisiana Division of Archaeology to report an isolated historic ceramic sherd found in a pimple mound in Tract 101 and an historic residence or farmstead located in Tract 211 (Appendix B).

After the artifacts were washed (or dry brushed in the case of bone, shell, and metal) and dried, a description of each item from a single provenience (i.e., shovel test) was recorded in a standard format. This included the catalog number, location or site number, provenience, excavation level, excavator, and date the artifacts were recovered. Beneath this heading, the artifacts were divided into gross categories: ceramics, curved glass, flat glass, nails, other architectural (e.g., brick, concrete, etc.), miscellaneous metal, bone, shell, and other. A summary of the artifact catalog is included with this report as Appendix D. Tabular summaries were then prepared from the artifact catalog.

Where applicable the site number and/or the catalog number were written in India ink on all of the ceramics and glass in the assemblage. This number is protected by a veneer of polymer as per the Louisiana state curatorial quidelines. The artifacts were separated by material (i.e., ceramic, glass, metal, faunal, etc.) and placed into archival quality resealable plastic bags. All materials from the same provenience were then placed into larger plastic bags. Each large bag contains an Artifact Card listing the catalog number, site number or location, shovel test number or grid location, level, excavator, and date the artifacts enclosed were recovered. The large bag is marked on the exterior with the appropriate catalog number.

Artifact analysis focused primarily on the glass and ceramic items, which generally provide chronological and functional information. Ceramics were classified according to standard ware types, while glass embossments and technological features were used for dating purposes. Where possible, ceramic and glass vessel forms were also determined. 


\section{FIELD SURVEY RESULTS}

\section{A. Survey Area 1}

Survey Area 1 includes the Pleistocene Prairie Terrace area that extends from the northern terminus of the ROW to Bayou Choupique. Altogether, this segment encompasses approximately 4.75 miles $(7.64 \mathrm{~km})$ of the ROW. Within Survey Area 1, four high probability areas were identified. Three areas of prehistoric sensitivity correspond to three bayous or sloughs in Section 35, T $9 \mathrm{~S} ., \mathrm{R} 10 \mathrm{~W}$. Two areas of historic sensitivity were identified, located to the north and south of State Rt. 1133; of these, the northern area corresponds to one of the areas of prehistoric sensitivity. The remainder of Survey Area 1 was considered to have low archaeological sensitivity.

Present land use in Survey Area 1 consists primarily of pasture and fallow fields, but there are also some cultivated fields and small marsh areas. One historic archaeological site (16CU205) was identified in this segment, at one of the predicted sensitivity areas. Also, a recent trash dump and a small shack were recorded during the survey.

The placement of survey transects and shovel tests for Survey Area 1 is indicated in Figures 6, 7, 8, 9 , and 10. At the northern terminus of the ROW, survey began with the establishment of of Transects A and B along State Route 1133. Because an unnamed bayou was visible on the aerial photographs, this area was defined as a potential prehistoric sensitivity area, so that shovel tests were placed at 25-meter intervals for the entire length of Transects A and B. There are numerous pipelines in the area south of the unnamed bayou, and the shovel tests along Transect A exhibited disturbed soil profiles. The unnamed bayou that crosses Transects A and B proved to be an extremely minor drainage, with a channel width of less than two meters (six feet); modern debris and shell from the adjacent road were observed in the cut bank, but nothing of cultural significance.

The meter station site (Plate 1) encompasses an area of approximately three acres, which was in high pasture grass at the time of the survey. This area was tested by the placement of 12 shovel tests on transects C, D, E, F, G, and H, with completely negative results. Shovel Test C1, located at the southeast corner of the meter station site, exhibited a disturbed profile, possibly a result of prior pipeline construction. Shovel tests throughout the remainder of the meter station site appeared to represent a relatively intact land surface, but the varying depths to subsoil may indicate that the field was leveled. Immediately west of the meter station site, spoil piles were noted along Transect $G$ at what would have been the location of Shovel Test No. 3 on that transect. This lends support to the interpretation that the meter station sile had been leveled.

Transects $\mathrm{G}$ and $\mathrm{H}$ extended west from the meter station site along the ROW and crossed a second unnamed bayou. As noted above, Shovel Test No. 3 on Transect $G$ was not excavated because of spoil piles. Beginning at Shovel Test No. 5 on Transects G and H, the interval was reduced to 25 meters, as the margins of the bayou had been defined as a high potential area for prehistoric resources. East of the bayou, the ROW passed through an old pasture, and the bank of the bayou was heavily overgrown with trees and vines. The west side of the bayou was in open pasture with a few scattered trees. The cutbanks of the bayou were inspected but with negative results. Shovel Tests $(\mathrm{G} 10, \mathrm{G} 11, \mathrm{H} 10$, and H11) immediately to the west of the bayou included redeposited clay subsoil in the surface levels, indicating that the bayou had been dredged, apparently to improve drainage.

Approximately 330 feet $(100 \mathrm{~m})$ west of the bayou, a small shed is within the ROW. The shed is constructed of dimensioned lumber frame covered with corrugated sheet metal siding and a dirt floor. 


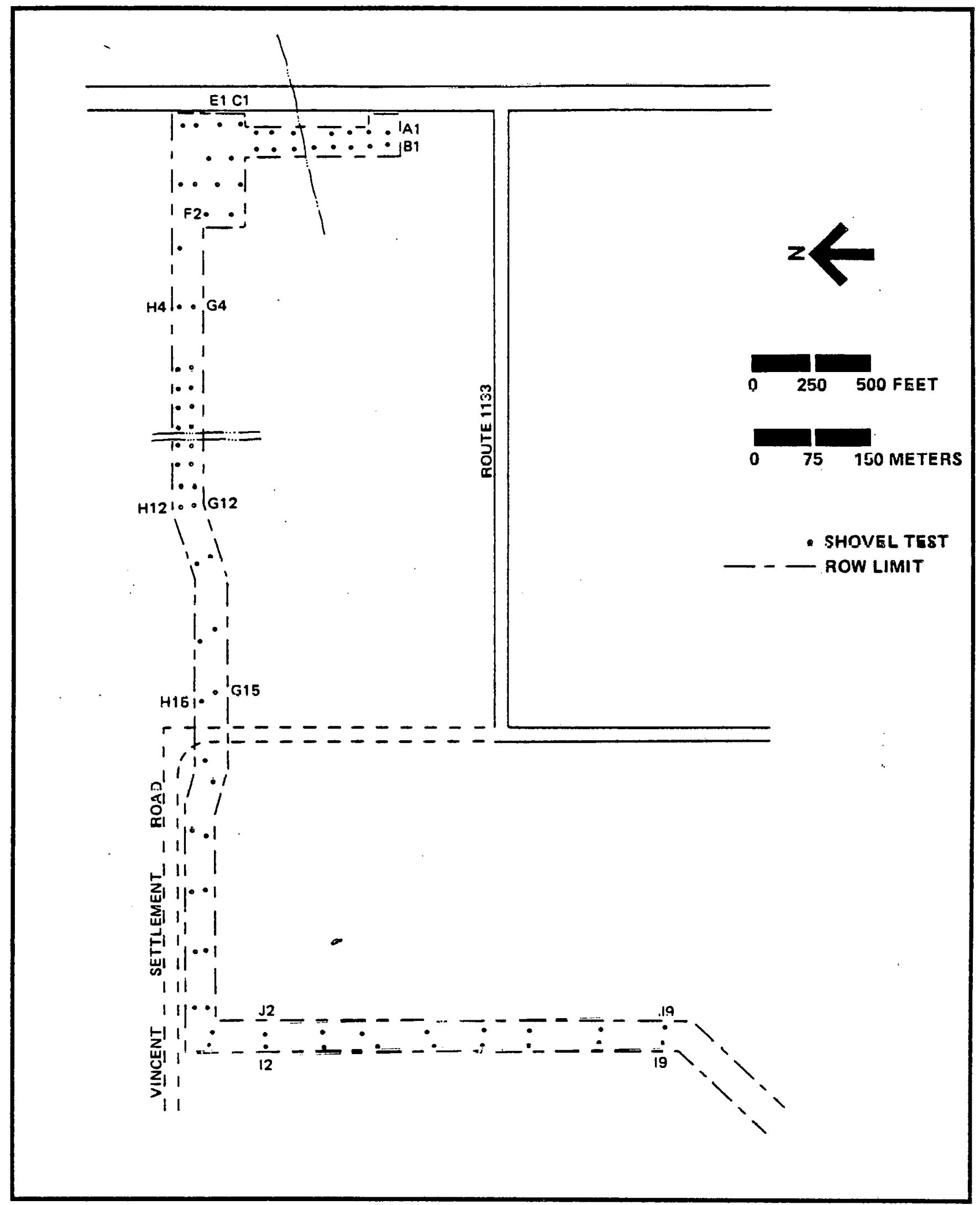

FIGURE 6. Survey Area 1, Transects A, B, C, D, E, F, G, H, I and J. 


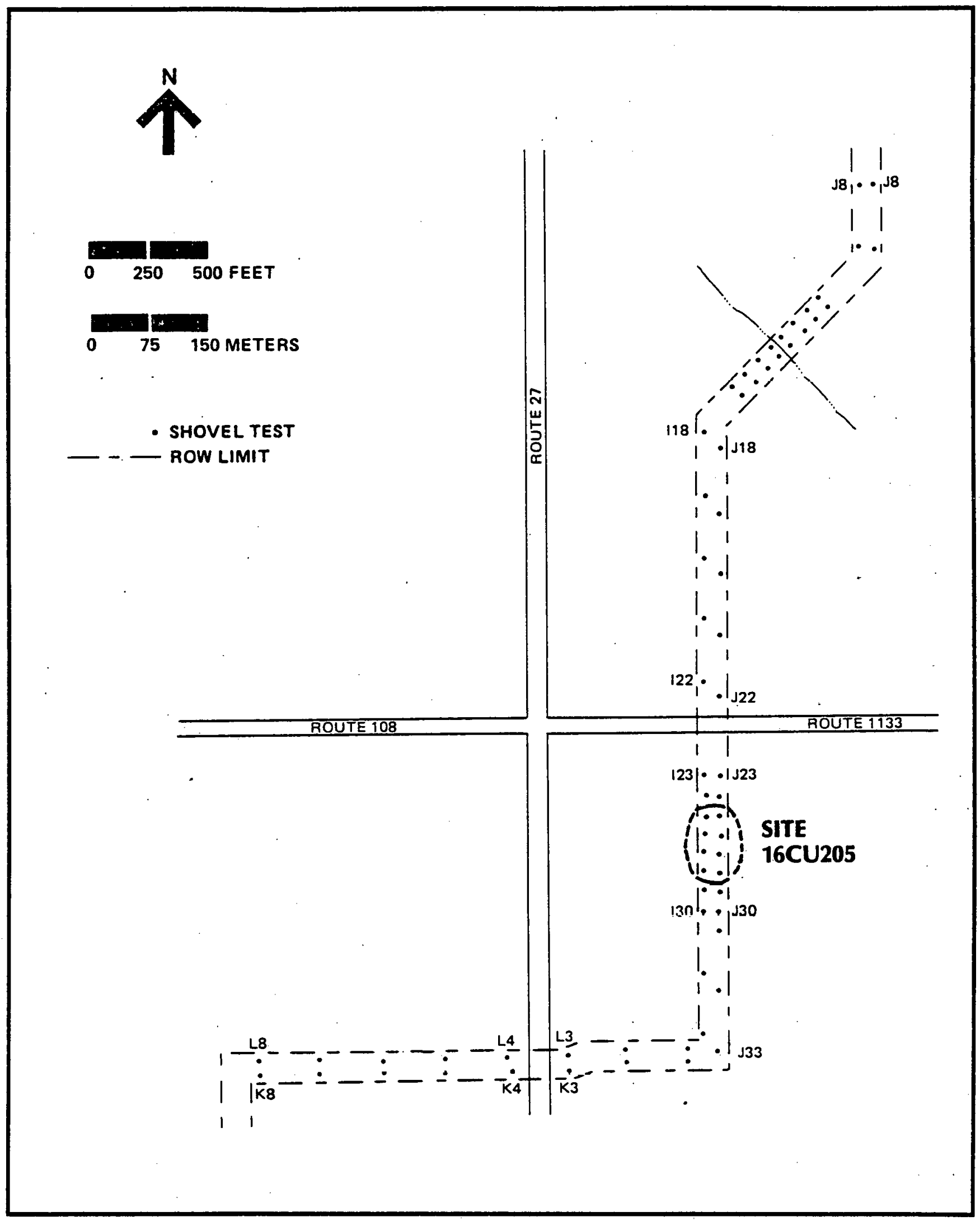

FIGURE 7. Survey Area 1, Transects I, J, K and L. 


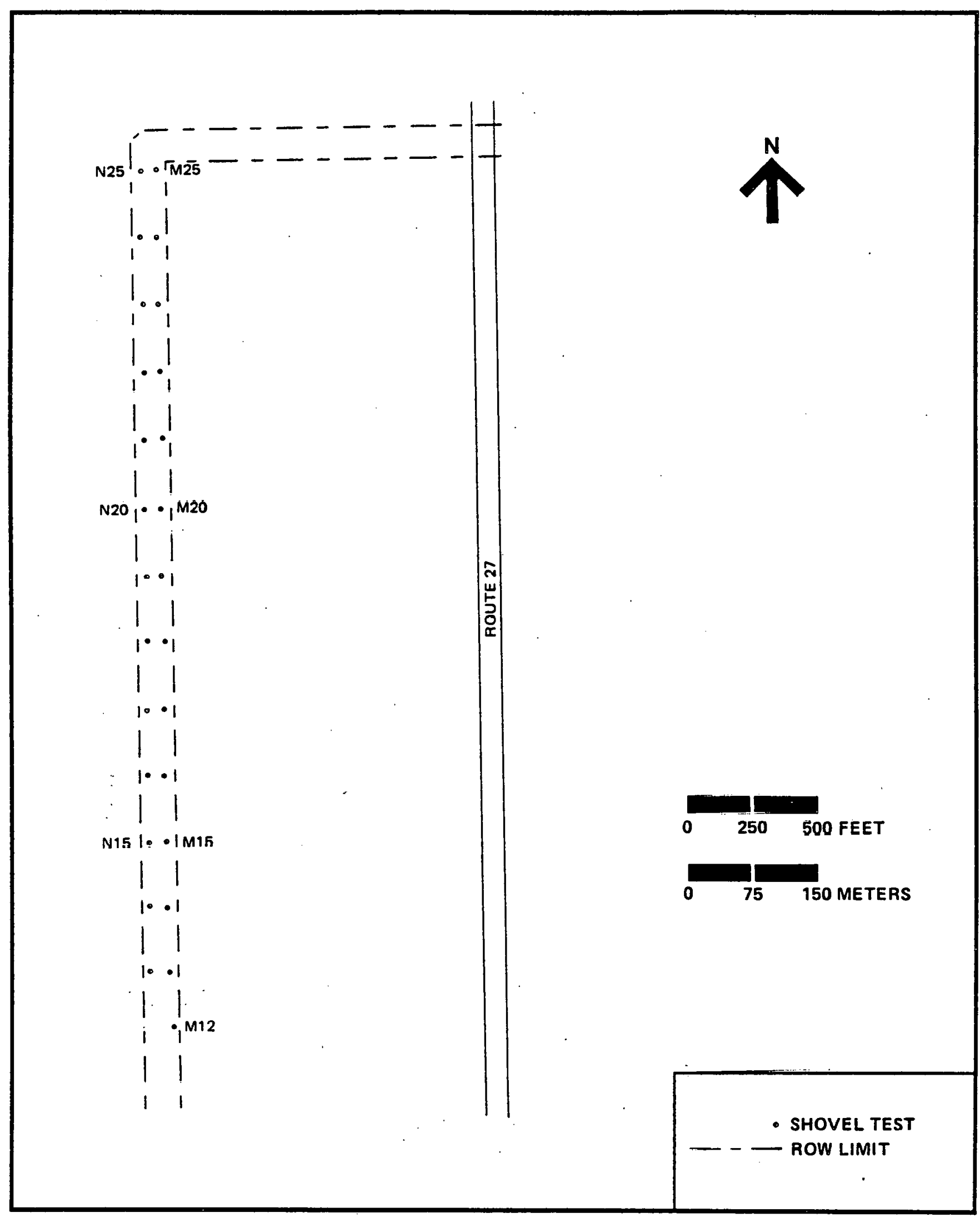

FIGURE 8. Survey Area 1, Transects $M$ and N (northern section). 


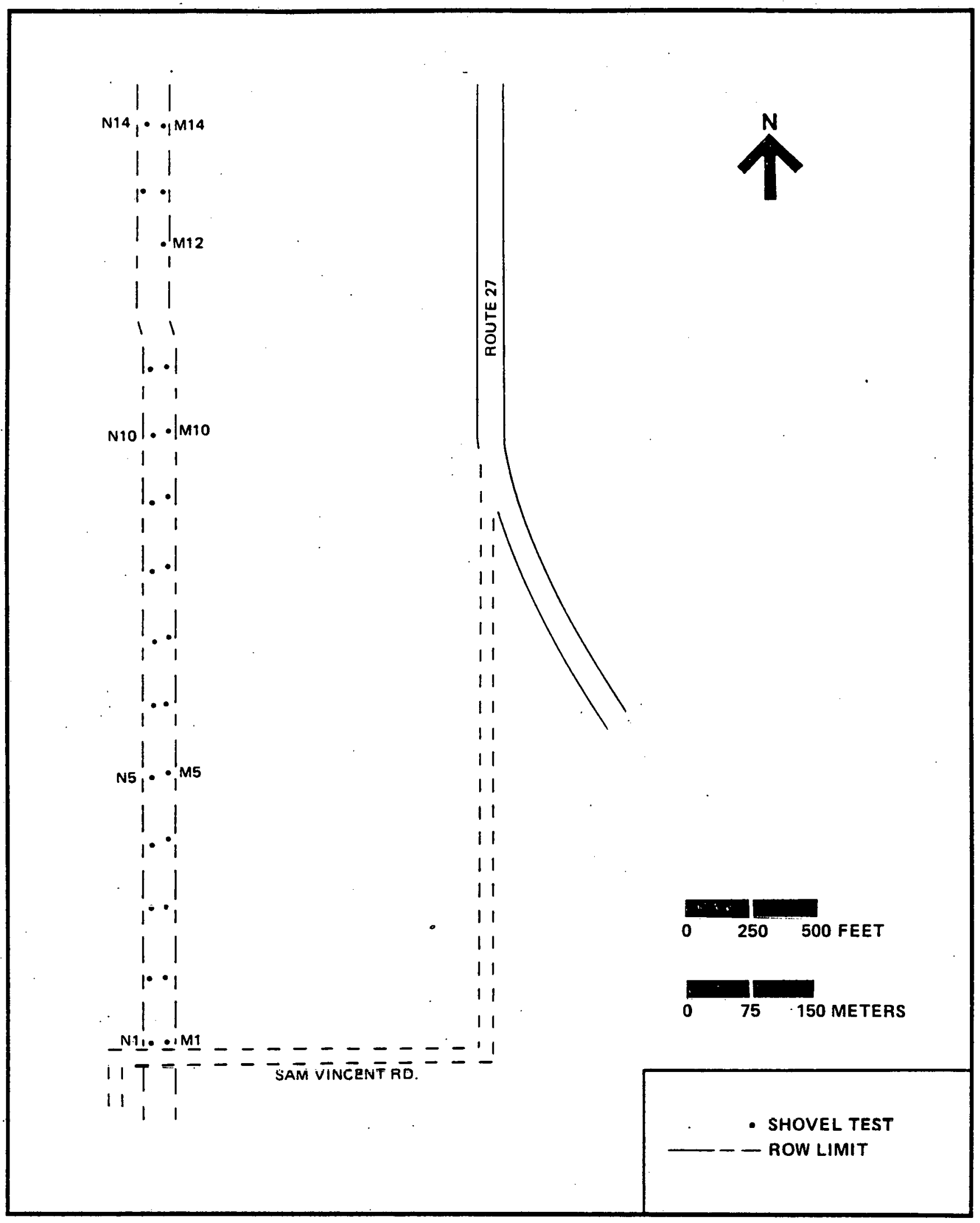

FIGURE 9. Survey Area 1, Transects $M$ and N (southern section). 


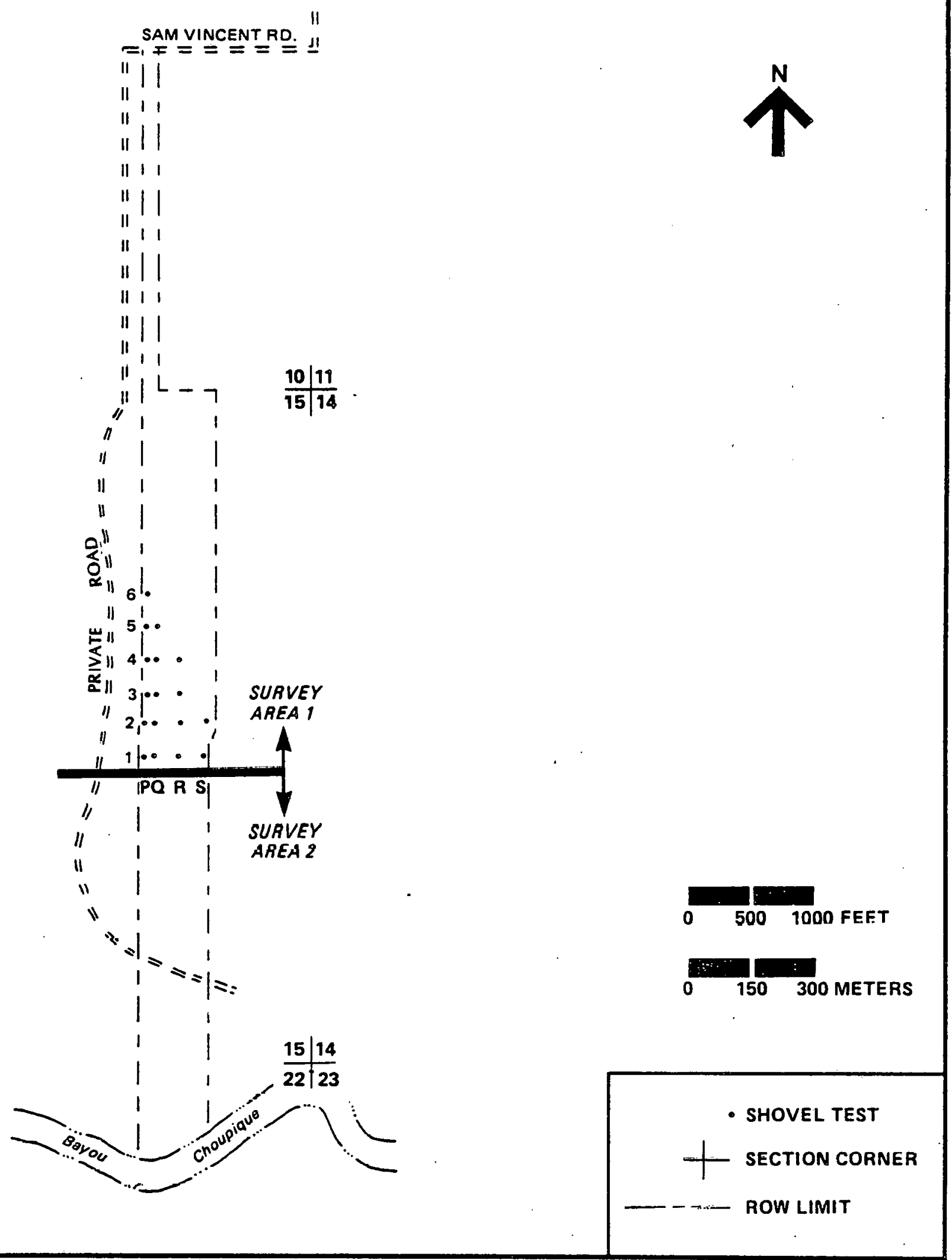

FIGURE 10. Survey Area 1 , Transects $P, Q, R$ and $S$. 


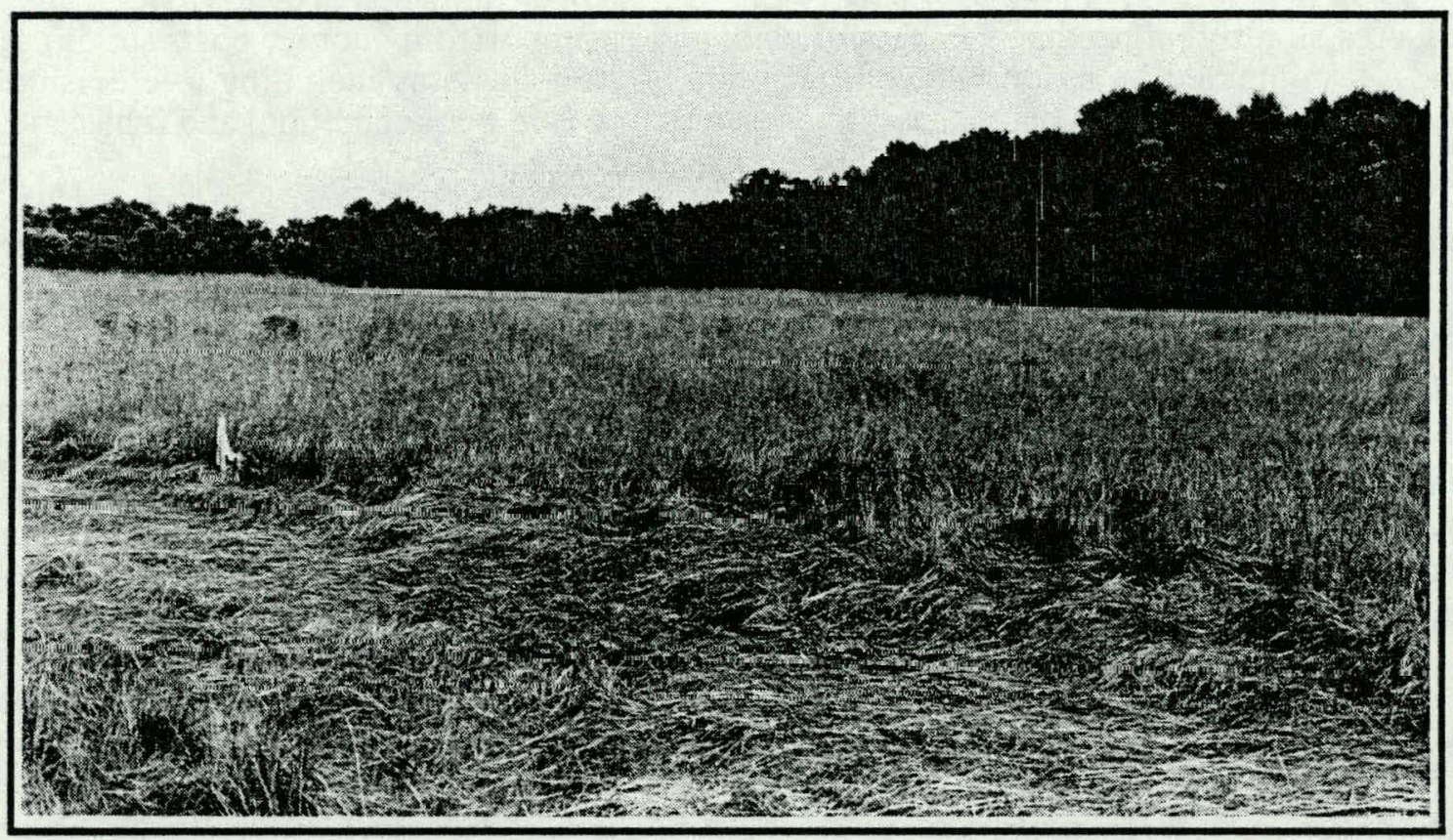

PLATE 1. Meter Station Site, Survey Area 1, Facing Northwest.

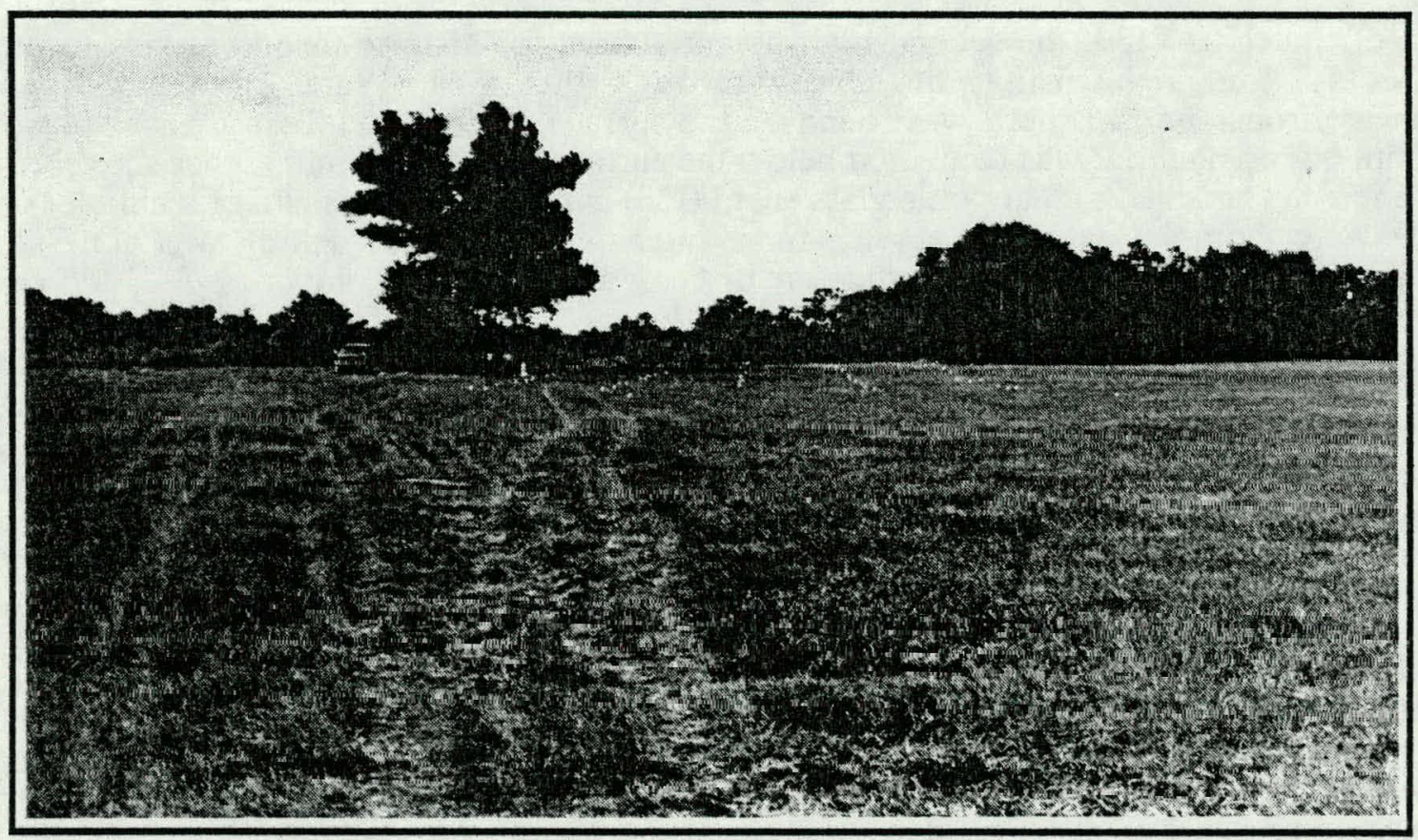

PLATE 2. Site 16CU205, Survey Area 1, Facing South. 
It measures slightly larger than $7 \times 7$ feet in plan, and is supported by corner posts set directly in the ground. It contained an assortment of discarded household items including a television cart, an aluminum lawn chair, and a barbecue grill. The structure is in poor condition, and it has an estimated age of perhaps 20 years. It is of no architectural significance.

West of the shed, the ROW continued through a pasture and an area of planted pine trees immediately to the east of Vincent Settlement Road. As the ROW extends to the west along Vincent Settlement Road, it passes through a large open field of high pasture grass. While this area was designated as a low probability area, a number of pimple mounds in this field were observed, and the shovel testing interval was adjusted to allow testing of these features. Pimple mounds were tested at shovel test locations $\mathrm{G} 17$ and $\mathrm{H} 18$ but with negative results. Transects I and J were established at the point where the ROW turns south from Vincent Settlement Road (Figure 6). The northern portion of Transects I and J was identified as a low potential area, but the normal 80-meter shovel test interval was adjusted to test a number of pimple mounds in this area. Pimple mounds were tested at locations $\mathrm{I} 1, \mathrm{~J} 3$, and $\mathrm{J} 6$, but with negative results.

Transects I and $\mathrm{J}$ crossed the third of the bayous that were designated as high potential areas for prehistoric sites within Survey Area 1, and this stream crossing was also identified as a high potential area for historic sites. Accordingly, the shovel test interval was adjusted to 25 meters in this area. The bayou appeared to have been recently dredged, as the immediately adjacent shovel tests exhibited overbank deposits or dredged spoil. No evidence was found of either historic or prehistoric occupation of this area. Given the distance from the nearest road, it is suggested that the structure indicated on the early twentieth century map was a barn or other agricultural outbuiding. South of the bayou, the ROW continued through pasture areas, and one pimple mound was tested at Shovel Test $\mathrm{J} 17$.

South of State Rt. 1133, the second high potential area for historic resources was located along Transects I and J. During the survey through this area (Plate 2), a small, embossed whiteware/ironstone rim sherd was found on the surface, and Shovel Test 126 was placed at that location, but no material was recovered below the surface at that location. Other shovel tests in the adjacent area contained a clear bottle glass sherd (I28) and a clear glass sherd of a tumbler or jelly jar (J27). After completion of the survey, more intensive subsurface testing was done at this site (16CU205), and the results of this testing are discussed in Section F below.

Immediately south of a barbed wire fence to the south of site $16 \mathrm{CU} 205$, a recent trash dump was identified in Shovel Test I29. The contents were of modern origin and included brick, clear, green, and milk glass, and a section of plastic tubing, possibly a hula hoop. A number of residences were located in the immediately adjacent area, and the trash deposit is probably attributable to one or more of the current occupants. South of the trash dump, the ROW continued through an unused pasture, and no other cultural material, aside from abandoned cars, was found along Transects I and J.

Transects $\mathrm{K}$ and $\mathrm{L}$ were laid out along an east-west segment of the ROW that crosses State Rt. 27 (Figure 7). This area is comprised of cow and horse pastures and was surveyed with shovel tests at 80 -meter intervals. No cultural material was located along either Transect $\mathrm{K}$ or $\mathrm{L}$. Transects $\mathrm{M}$ and $\mathrm{N}$ were established to sample the ROW that extends north from Sam Vincent Road (see Figures 8 and 9). This portion of the ROW extends through a succession of pastures and overgrown fields, and it was treated as a low probability area. No pimple mounds or natural drainages occur in this area, so that it was sampled by shovel tests at 80 -meter intervals. One marshy area between shovel test locations 11 and 12 could not be tested. 
The area between Sam Vincent Road and Bayou Choupique (Figure 10) was surveyed with Transects $\mathrm{P}, \mathrm{Q}, \mathrm{R}$, and $\mathrm{S}$. Most of this area was in active cultivation, so that the survey was accomplished by walkover inspection. The southernmost portion of Survey Area 1 was in cow pasture, and this area was surveyed by shovel tests along Transects P, Q, R, and S. Between the cultivated fields and pasture, areas of marsh or drainage ditches were not tested. No high potential areas were defined in this area, and no archaeological resources were identified during the survey.

Three farm outbuildings were located in the lower end of Survey Area 1. They were documented photographically and by scaled plan drawings during the survey, but they lack sufficient historical association or architectural merit to be considered as significant cultural resources.

Tract 115 contained a cow barn that had fallen into disrepair (Plate 3 ). It was a simple pole frame structure with a gable roof and a dirt floor. Three sides were framed with dimension lumber and sheathed with corrugated sheet metal. In plan (Figure 11), it measures approximately $17 \times 51$ feet $(5 \times 15.5 \mathrm{~m})$, and it appears to be 30 to 40 years old.

A cluster of two outbuildings were located in Tract 112, both of which were in active use. These buildings appear to have been constructed within the past 20 years, and they do not appear on the 1955 quadrangle map of the area (USGS 1955). One, a hay barn that measures $18 \times 30$ feet $(5.5 \times 9.1$ $\mathrm{m}$ ) in plan, has a frame of dimensioned lumber that rests on creosote-treated ground sills, and it is sheathed with corrugated metal applied to the sides and roof. It has a shed roof that projects to the side of the structure, providing an open animal shelter area. Access is provided by two sliding doors on the south facade and one hinged door on the north side. The other structure was constructed by applying corrugated sheet metal directly over a series of arched metal pipes. It measures $19 \times 30$ feet $(5.8 \times 9.1 \mathrm{~m})$ in plan and is open on one end.

\section{B. Survey Area 2}

Survey Area 2, approximately 1.0 -mile $(1.6 \mathrm{~km})$ in length, is centered on the crossing of Bayou Choupique, and it corresponds to the Recent Alluvium geological unit. Throughout Survey Area 2, the ROW is approximately 500 feet $(150 \mathrm{~m})$ wide, to accommodate temporary construction activities. Within this survey area, the margins of Choupique Bayou had been identified as a high potential area for prehistoric sites. No historic or prehistoric sites were identified in this survey area. Virtually all of this survey unit was comprised of marsh, and only a few areas could be reached by vehicle or by foot.

North of Bayou Choupique, Survey Area 2 was accessible by an unimproved shell road that led to an abandoned oil well (see Figure 10). The areas within approximately 100 meters of this road were dry enough to permit a walkover examination, and because of extensive sheet erosion, there was sufficient ground exposure to preclude the necessity for shovel testing. Aside from occasional shells which were attributable to the road fill, there was no evidence for cultural activity in this area.

Extensive marsh areas occupied both the north and south banks of Bayou Choupique (Plate 4). A boat survey was undertaken along both banks, but no high banks were visible on either side of the bayou. A few shovel tests were attempted on either bank, but the ground surface was totally submerged.

South of Bayou Choupique, Survey Area 2 was accessible by foot from Survey Area 3 (Figure 12). Transects A, B, C, and D were extended from Survey Area 3 toward the bayou. This area was covered by high grass, with scattered wet areas, and a total of 17 shovel tests were placed in this 


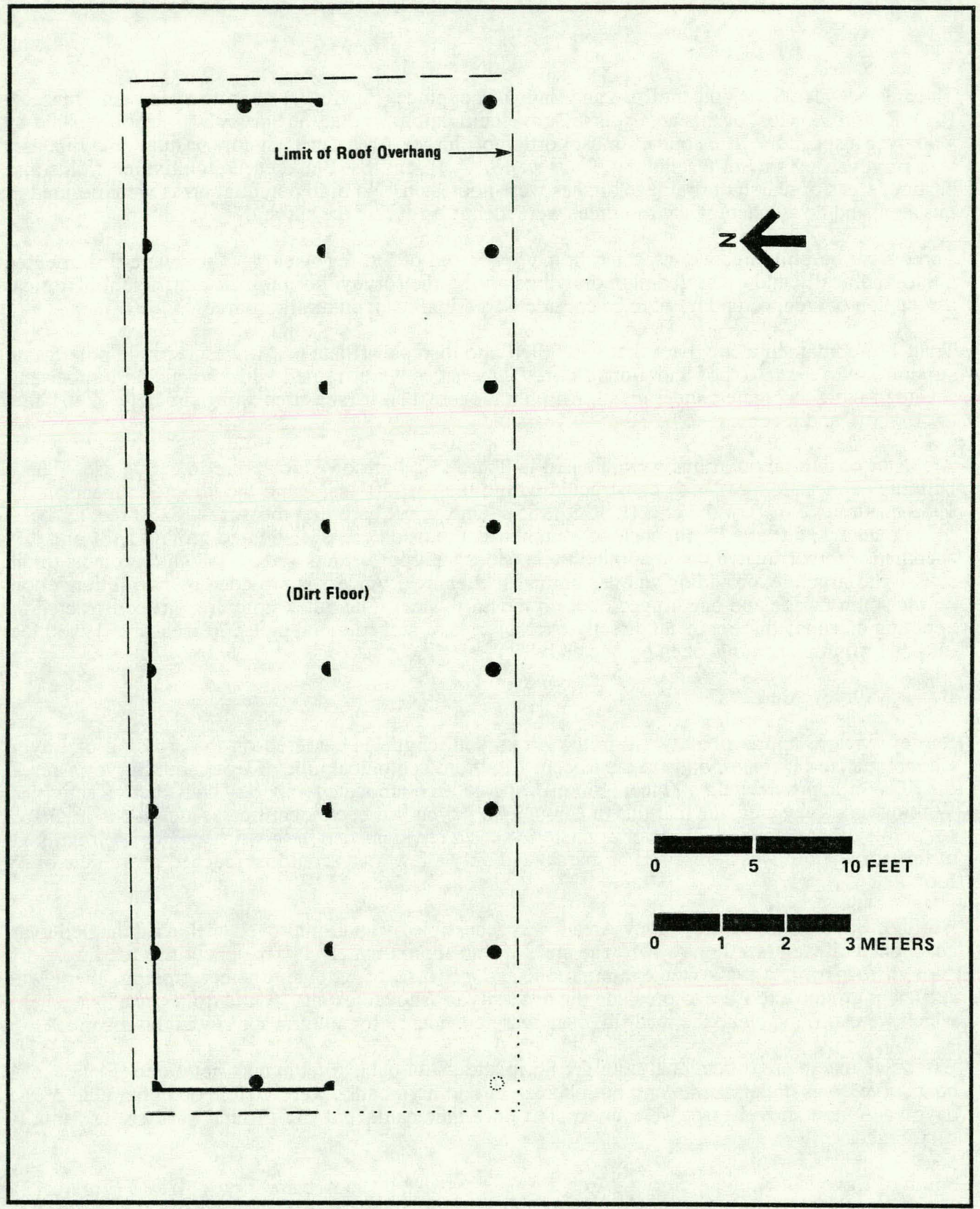

FIGURE 11. Plan of Cow Barn, Survey Area 1, Tract 115. 


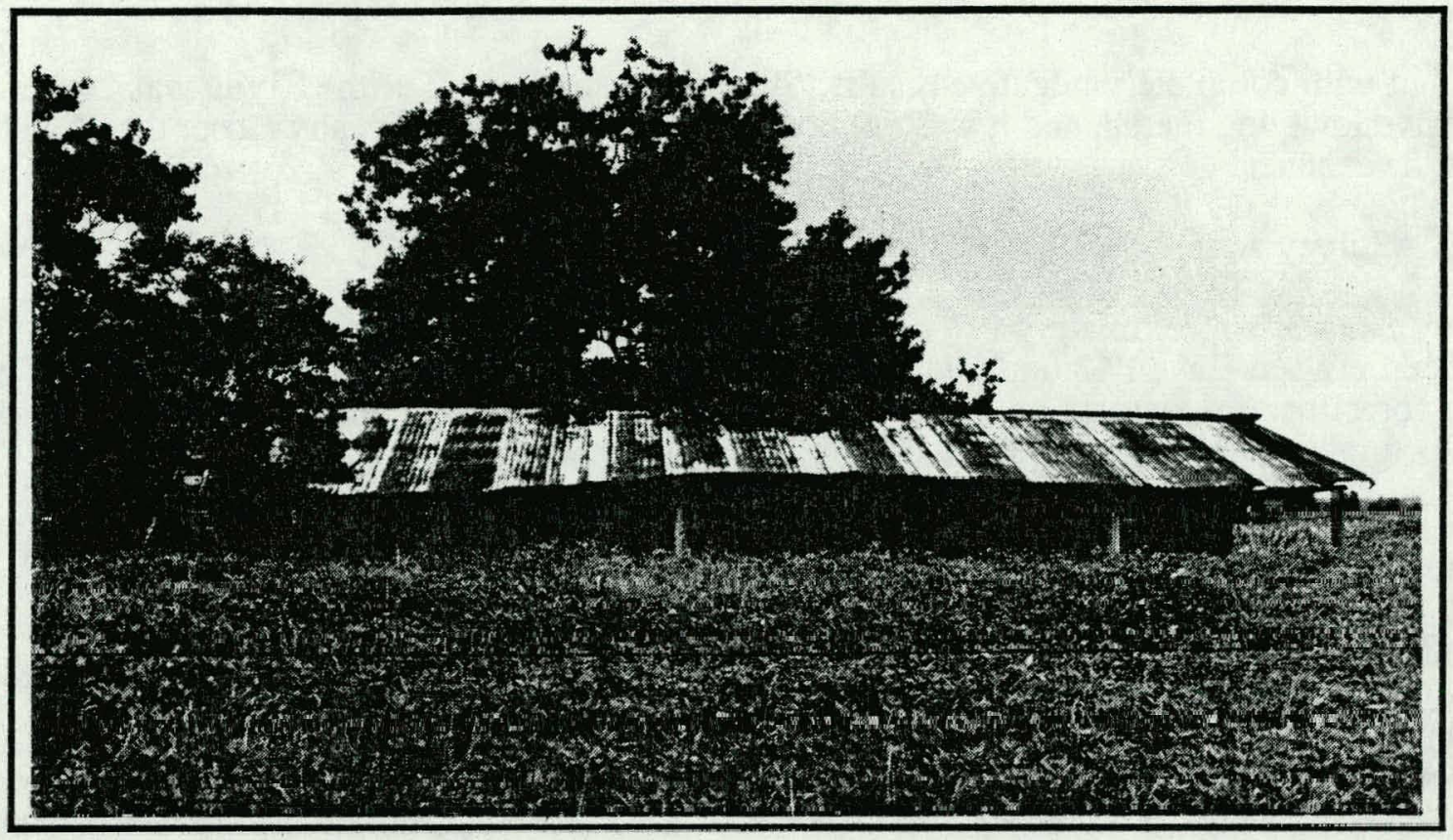

PLATE 3. Cow Barn, Survey Area 1, Tract 115, Facing North.

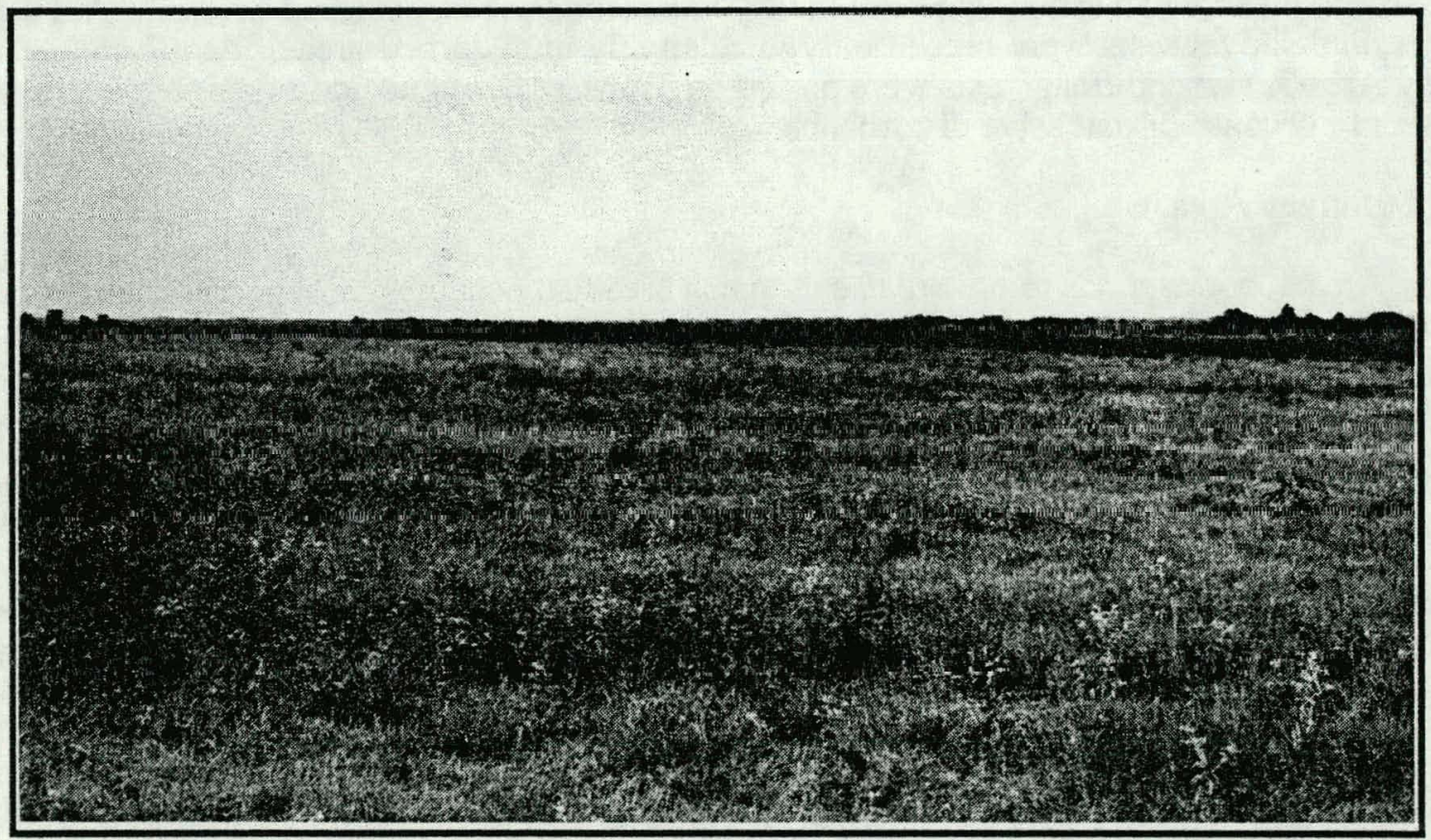

PLATE 4. Bayou Choupique Crossing, North Bank, Survey Area 2, Facing North. 
area, but with completely negative results. Again, the south bank of the bayou was bordered by an extensive lowlying marsh, and it was not possible to place shovel tests any closer than 500 feet (150 m) to the channel.

\section{Survey Area 3}

Survey Area 3, approximately 0.7 -mile $(1.2 \mathrm{~km})$ in length, includes an area of Pleistocene Prairie Terrace between Bayou Choupique and the Marsh Land. There were no predicted high potential areas for either prehistoric or historic resources within this segment, and no archaeological or architectural resources were identified during the field survey.

The area was readily accessible from Moss Ellis Road, and survey transects were extended to the north and south of the road along the ROW (see Figure 12). Transects A and B extended north from Moss Ellis Road, through high pasture grass. Shovel Test locations 1 through 4 were placed within the pasture area. Approximately 1000 teet $(300 \mathrm{~m})$ north of the road, the KOW expands to a width of 500 feet $(150 \mathrm{~m})$ to accommodate a temporary construction area needed for the Bayou Choupique crossing. Two additional transects, $\mathrm{C}$ and $\mathrm{D}$, were established at that point, to allow coverage of the temporary construction area. The numbering of shovel tests along Transects $\mathrm{C}$ and $\mathrm{D}$ began at 5 , to maintain consistency with the adjacent Transects A and B. Beginning at shovel test location 5, the vegetation changed from pasture grass to marsh grasses, which continued north into Survey Area 2. One pimple mound was sampled at Shovel Test B5, but it contained no cultural material.

Transects $\mathrm{E}$ and $\mathrm{F}$ were established to the south of Moss Ellis Road. The first four shovel tests on each transect were placed within a cow pasture, while Shovel Tests E5 and F5 were within a forested area. South of Shovel Tests E5 and F5, the ROW is extensively disturbed by two parallel drainage ditches, and shovel tests were placed only in relatively undisturbed areas. At the southern end of Survey Area 3, two additional tests were placed on Transect E, but no additional tests were placed on Transect F, because of extensive disturbance.

\section{Survey Area 4}

Survey Area 4, corresponds to the broad salt marsh area that occupies most of the southern portion of the ROW. This segment is approximately 6.1 miles $(9.8 \mathrm{~km})$ in length, and it does not include any areas of predicted historic sensitivity. Inspection of historic maps and recent aerial photographs suggested that some stream channel margins in this area might not have been destroyed, and it was predicted that relict levees or high banks along these channels would have been attractive aboriginal habitation sites. These high potential areas correspond to the area immediately north of the Intracoastal Waterway and to the margins of Kelso Bayou, located in the southern portion of Survey Area 4, near Hackberry Island. The majority of Survey Area 4 was inundated, therefore the field survey was accomplished primarily by boat. Inspection of the predicted sensitivity areas indicated that no natural high banks were present, and no archaeological or architectural sites were identified during the field survey.

The northern terminus of Survey Area 4 was examined by extension of Survey Area 3 Transects E and F (see Figure 12). Two tests (8 and 9) were placed on Transect E, and one (9) was placed on Transect F. Immediately south of Shovel Tests E9 and F9 was an inundated marsh area that extended to the GIWW.

The remainder of Survey Area 4 was examined by boat. At the GIWW crossing, the ROW expands to accommodate a temporary construction area. The north and south margins of the GIWW are 


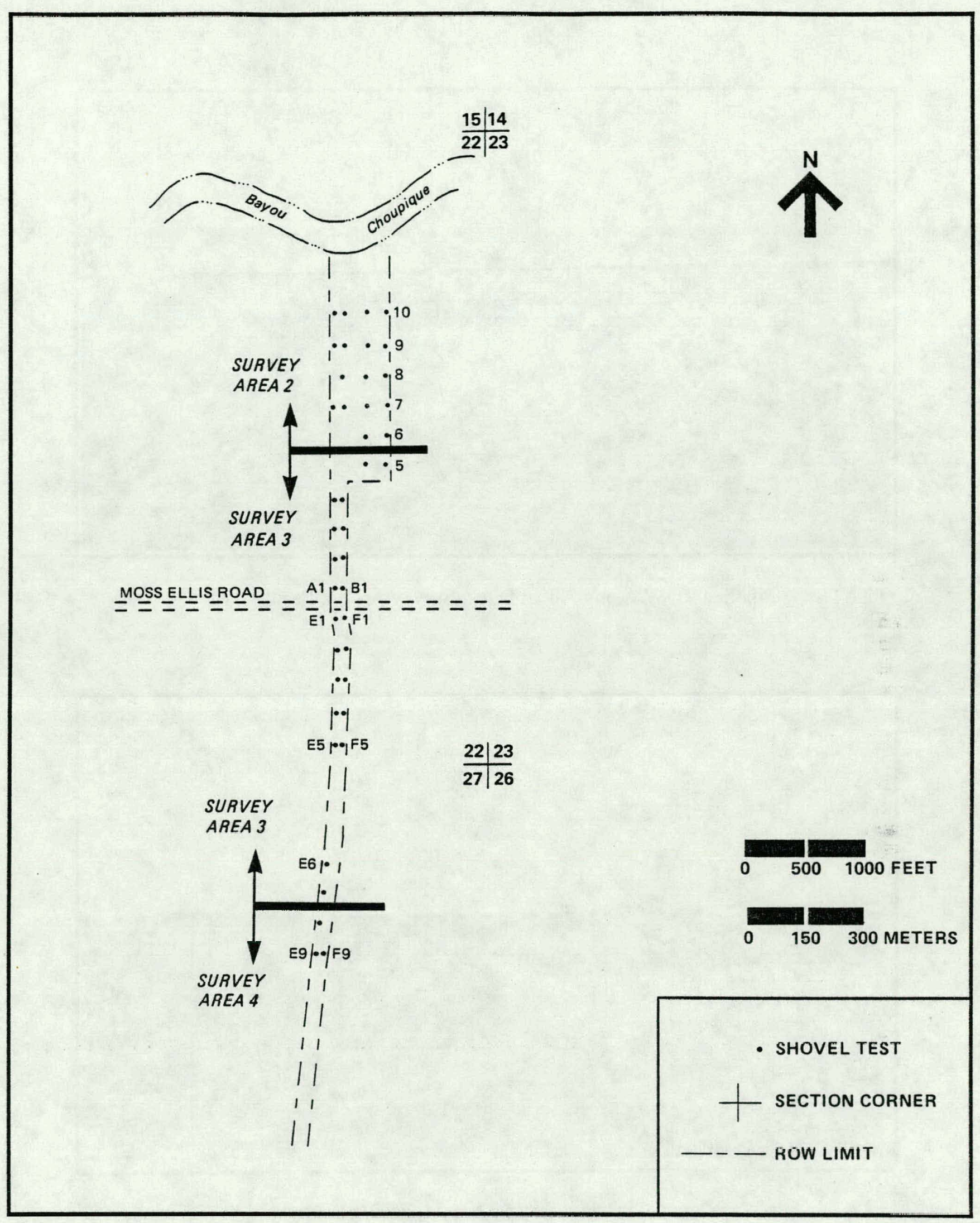

FIGURE 12. Survey Areas 2, 3 and 4, Transects A, B, C, D, E and F. 


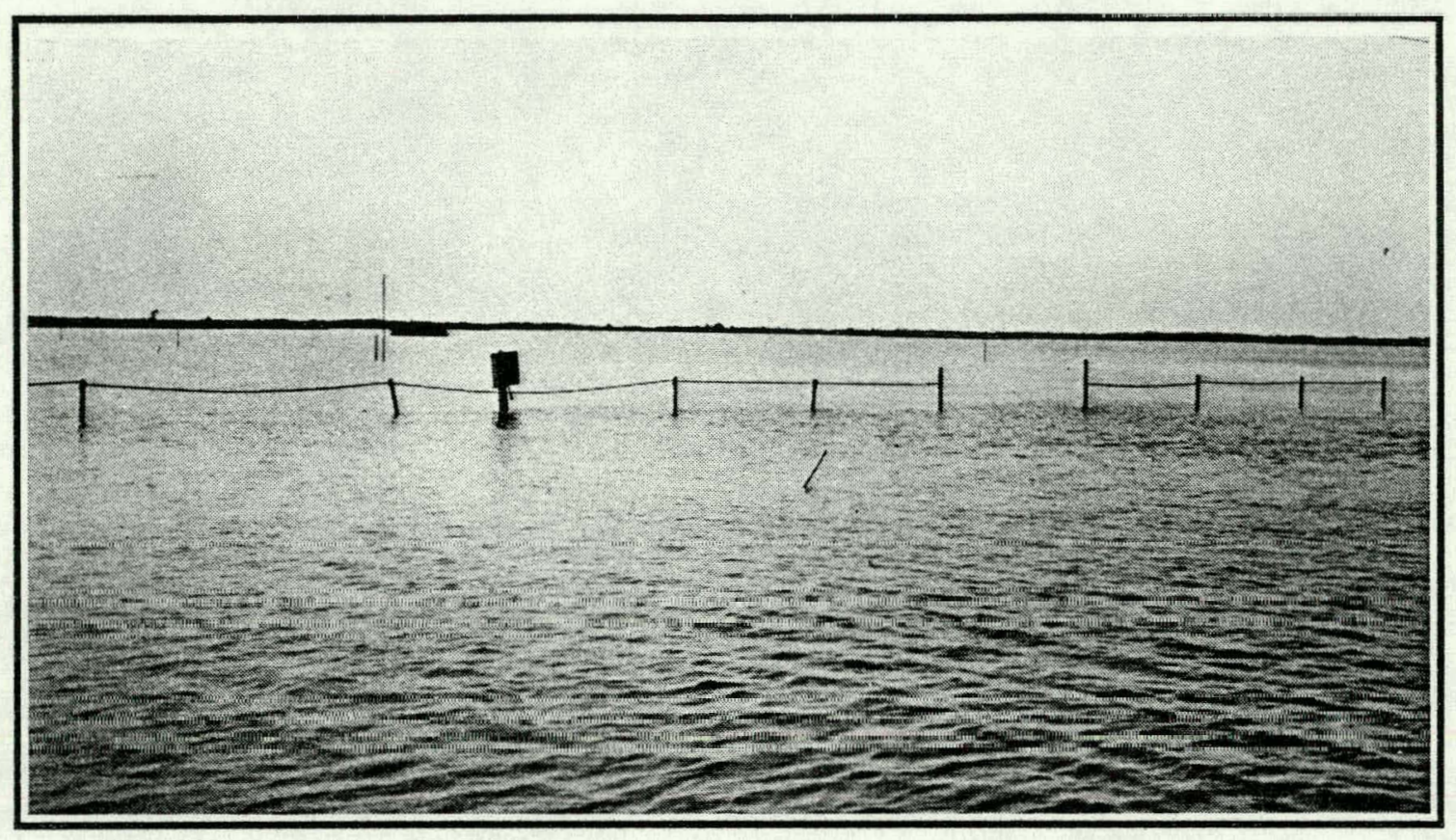

PLATE 5. Pipeline ROW Along Alkali Ditch, Survey Area 4, Facing East.

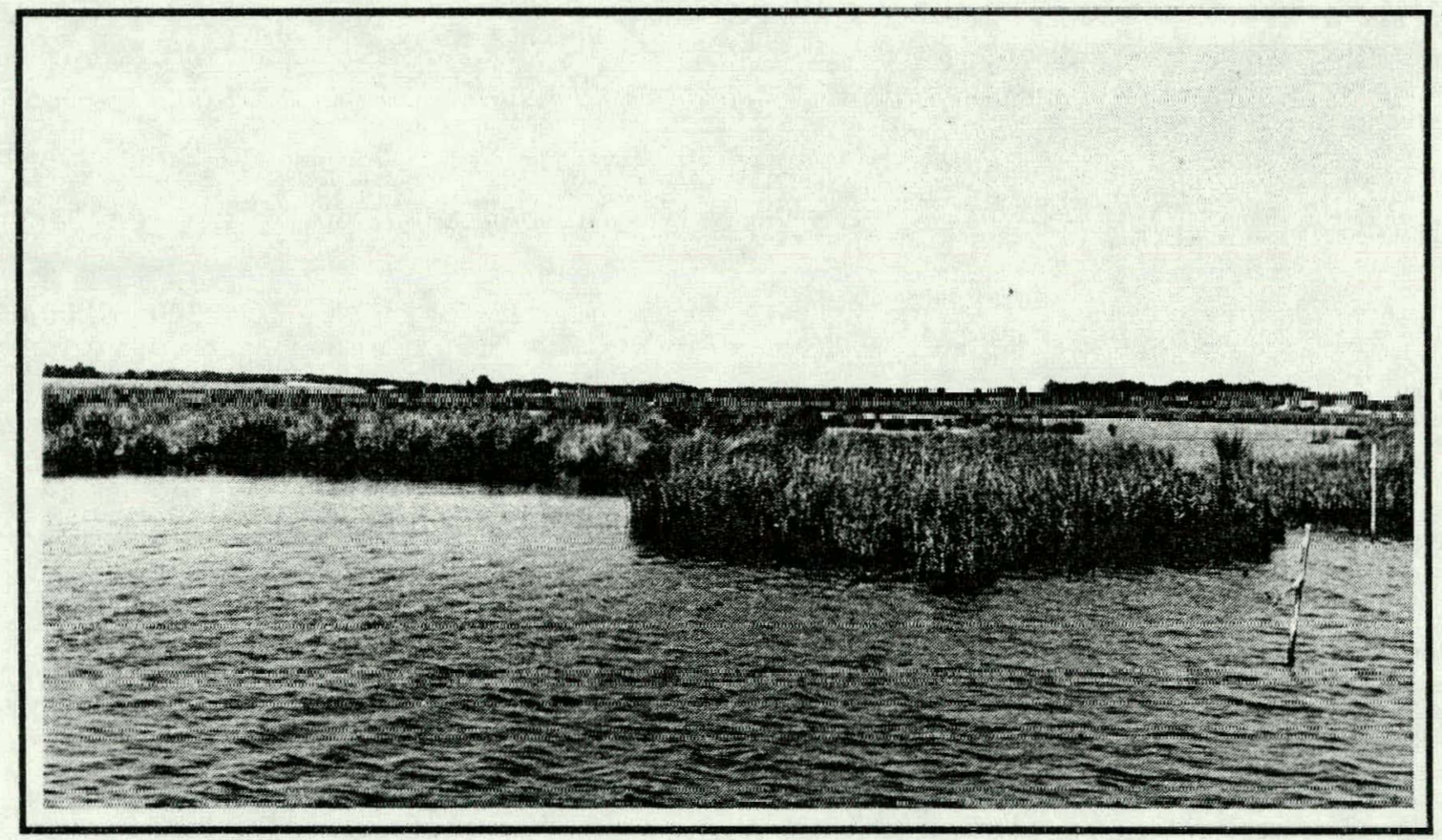

PLATE 6. Kelso Bayou Crossing, Survey Area 4, Facing Southwest. 
covered by massive dredged spoil deposits (see Figure 3). These deposits provide a habitable land surface, but they were not tested because of their recent origin. South of the GIWW, the ROW extends along Alkali Ditch, another recently dredged channel that contains and is flanked by numerous existing pipelines leading from the West Hackberry Oil Field. The northern portion of the ROW along Alkali Ditch was completely submerged (Plate 5) and was therefore not amenable to testing. In the southern portion of Survey Area 4, the ROW enters the West Hackberry Oil Field (see Figure 4) which has been extensively channelized. In this area, all land surfaces that were not submerged at the time of the survey consisted of spoil deposits. The crossing of Kelso Bayou (Plate 6) appeared relatively undisturbed, but it was completely submerged and therefore not tested.

\section{E. Survey Area 5}

Survey Area 5 includes an isolated area of Pleistocene Prairie Terrace which corresponds to the Hackberry Island area at the southern terminus of the ROW. This entire survey area was classified as a high potential area for both prehistoric and historic resources. No archaeological or architectural sites were identified in this segment of the ROW, although a few isolated historic items were recovered during shovel testing.

The ROW begins within Strategic Petroleum Reserve No. 3, but since this area had already been examined (Weinstein et al. 1979), the field survey for the present project began immediately outside the petroleum reserve compound. Transects A and B were established at the property boundary of the petroleum reserve and extended east along the ROW (Figure 13). Because the ROW was not staked in this area, the transect alignments were periodically adjusted with the assistance of the Fluor Environmental Manager. Shovel tests were placed at 25-meter intervals on both transects, except at the eastern end where extremely heavy vegetation necessitated an alternate strategy. The first eight shovel tests were within a forested area, which gave way to pasture, dense shrubs, and eventually marsh at the end of the survey area. By adjusting the interval between shovel tests and the transect alignments, a number of pimple mounds were sampled in the western portion of the survey area.

Pimple mounds were tested at Shovel Tests A6, B1, B2, B4, and B5. Shovel Test B5, Level 1 contained a coarse red earthenware sherd with a white underglaze slip and a clear overglaze. Four additional shovel tests were placed in a cruciform pattern, five meters to the north, south, east, and west of Shovel Test B5, but no additional material was recovered. The sherd was considered an isolated find and no additional testing was undertaken.

Because of a delay in gaining entry to one tract, survey was suspended after completion of Shovel Tests A15 and B15. When the survey was resumed, the numbering of shovel tests began with 17 on each transect. Systematic testing proceeded on each transect until a marshy area with extremely dense. overgrowth was reached. The survey team was able to enter this area only through a series of paths that had been cut with a bush hog. Ground visibility ranged up to $50 \%$ in accessible areas, so that walkover inspection provided sufficient survey coverage. Four judgmentally located shovel tests were placed in this area, and were recorded as. Random Transect. One clear bottle body glass sherd. was recovered from Shovel Test B23; this was attributable to modern littering activity and did not warrant additional investigation.

F. Testing of Site $16 C U 205$

After the ROW survey was completed, site testing was carried out in Survey Area 1, along Transects I and J. A few historic artifacts were recovered during the survey of this area, which corresponded to a mapped structure location that appears on an early twentieth-century topographic map (USGS 


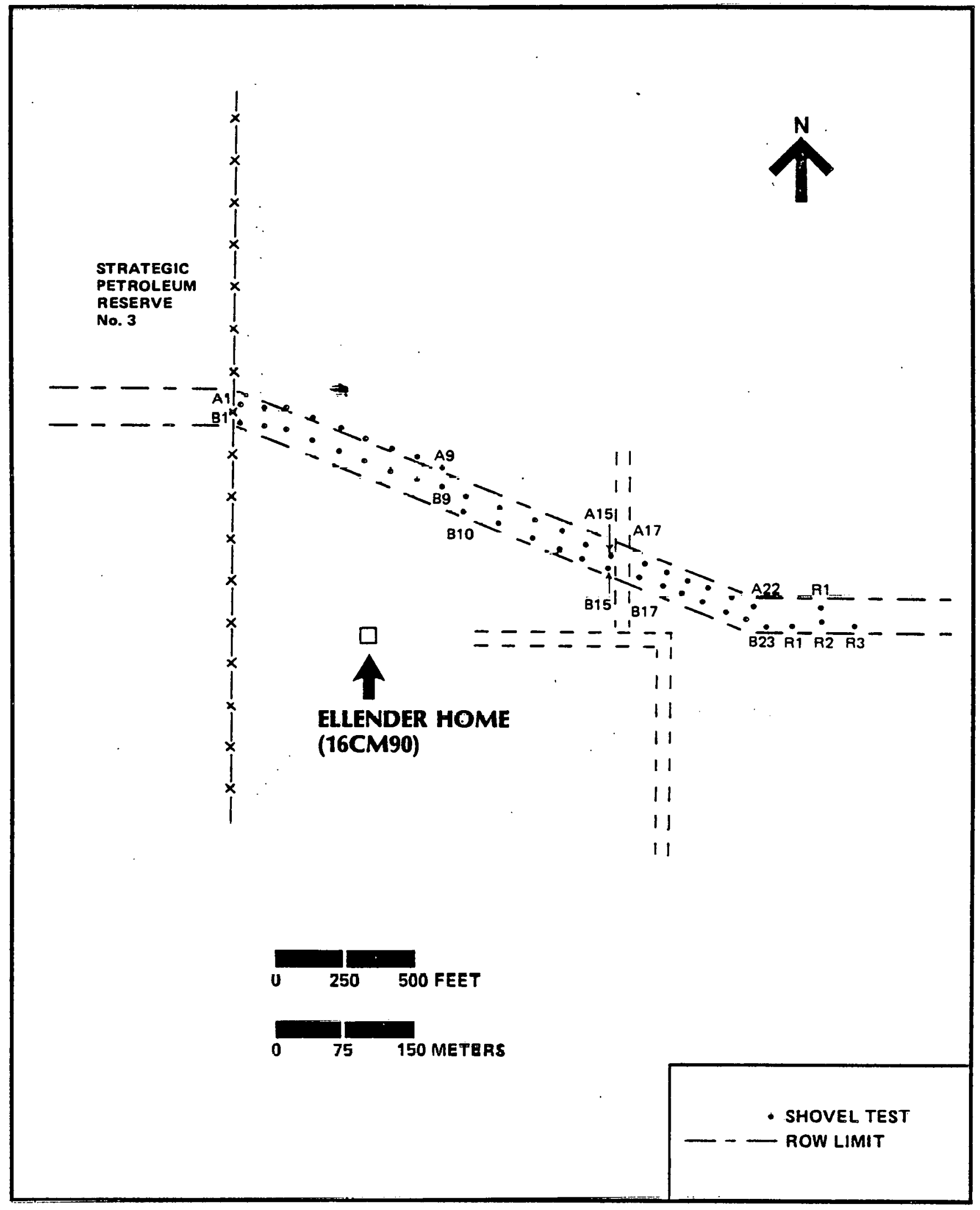

FIGURE 13. Survey Area 5, Transects A and B. 
1932). The site, assigned state number 16CU205, is located approximately 500 feet (150 m) south of State Rt. 1133, in a field of low pasture grass. A large sycamore tree is also within the site area (see Plate 2) along the edge of the ROW.

Site testing began with the establishment of a grid for for provenience control. Since the contract scope of work did not permit testing outside the ROW, the grid was aligned to the ROW centerline, which follows a north-south bearing through the site. The shovel tests on Survey Transects I and J were mapped to the grid, then a series of north-south transects were placed at 5-meter intervals across the ROW, and shovel tests were placed at 10-meter intervals along each transect. The placement of shovel tests was staggered along adjacent transects, providing a checkerboard sampling pattern, as shown in Figure 14.

Altogether, a total of 88 shovel tests were placed within the site area, of which 80 were placed according to the grid. Although the recovery of cultural material was somewhat sporadic, the shovel tests demonstrated that the site was confined to an area measuring approximately 80 meters in length within the ROW limits ( 38 meters). No foundations or other cultural features were visible on the surface, and none were identified in subsurface contexts.

Soil profiles varied somewhat throughout the site, but were most frequently characterized by a dark grayish brown (10YR 4/2) to very dark grayish brown (10YR 3/2) silt loam A-horizon that extended up to $48 \mathrm{~cm}$ below surface and brown (10YR 5/3) to grayish brown (10YR 5/2) silty subsoils. Typically, the A-horizon graded into the subsoil, and a plowzone was not evident in the profiles. The recovery of artifacts was generally limited to the sod layer and the A-horizon.

The artifacts recovered during testing are listed according to major artifact classes in Table 1, and a more detailed listing by provenience is provided in Appendix D. Figure 15 graphically portrays the density distribution of artifacts within the ROW. As seen in Figure 15, the distribution of artifacts indicates that the site extends for some distance outside the margins of the ROW. The greatest concentration of artifacts was observed along the eastern margin of the ROW, just south of the sycamore tree. (The tree was located near grid point $50 \mathrm{~N} / 40 \mathrm{E}$, hence no shovel test was placed at that point.) A second, minor concentration of artifacts was noted along the western margin of the ROW, centered on Shovel Test 25N/5E. The primary concentration contains an assortment of domestic and architectural debris which is indicative of a house site, while the secondary concentration is dominated by nails, and this may represent an outbuilding.

The datable ceramic and glass bottle elements in the assemblage are indicative of a twentieth-century occupation, although some of the ceramic types have a nineteenth-century beginning manufacturing date. The ceramic assemblage (Table 2) is dominated by whiteware/ironstone, with lesser amounts of yellow ware, stoneware, and porcelain. Ceramic vessel forms include a cup, two plates, two bowls, two possible crocks, and a few unidentifiable forms. The glass assemblage (Table 3 ) is dominated by clear curved glass sherds, with minor amounts of amethyst, cobalt, medium blue, aqua, blue tint, brown and milk glass sherds, as well as a few flat or window glass sherds. Glass vessel forms include at least two decorative forms, a tumbler, a lamp chimney, four bottles of indeterminate function, three jars, and a number of unidentifiable forms.

The remainder of the assemblage consists of nails, other architectural items, miscellaneous metal, bone, shell, and other items. All of the nails that were not too corroded for identification are of the machine-made, wire-drawn variety. Other architectural items include brick, slate and cement fragments. The Miscellaneous Metal category includes an iron scissors and a possible handle; and the remainder of this category is dominated by unidentifiable, corroded iron fragments. The bone 


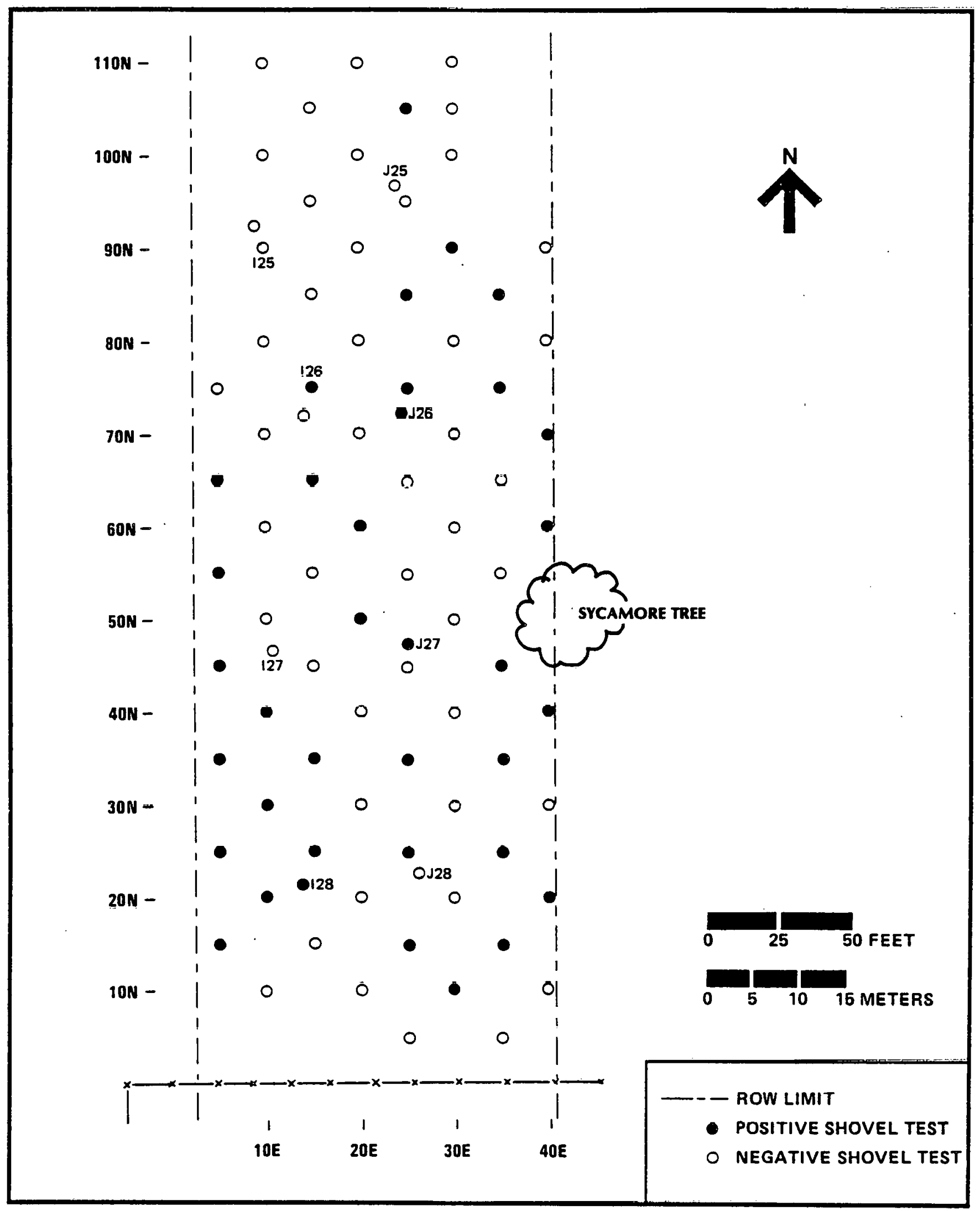

FIGURE 14. Site 16CU205, Plan of Shovel Tests. 
assemblage is limited to one burned, unidentifiable non-human mammal tooth and seven turtle carapace fragments. Shell includes a small amount of oyster and a number of fragments that were unidentifiable as to species. Other miscellaneous items include a phonograph record fragment, a cylindrical carbon rod (possible battery cell), tar, and charcoal. 


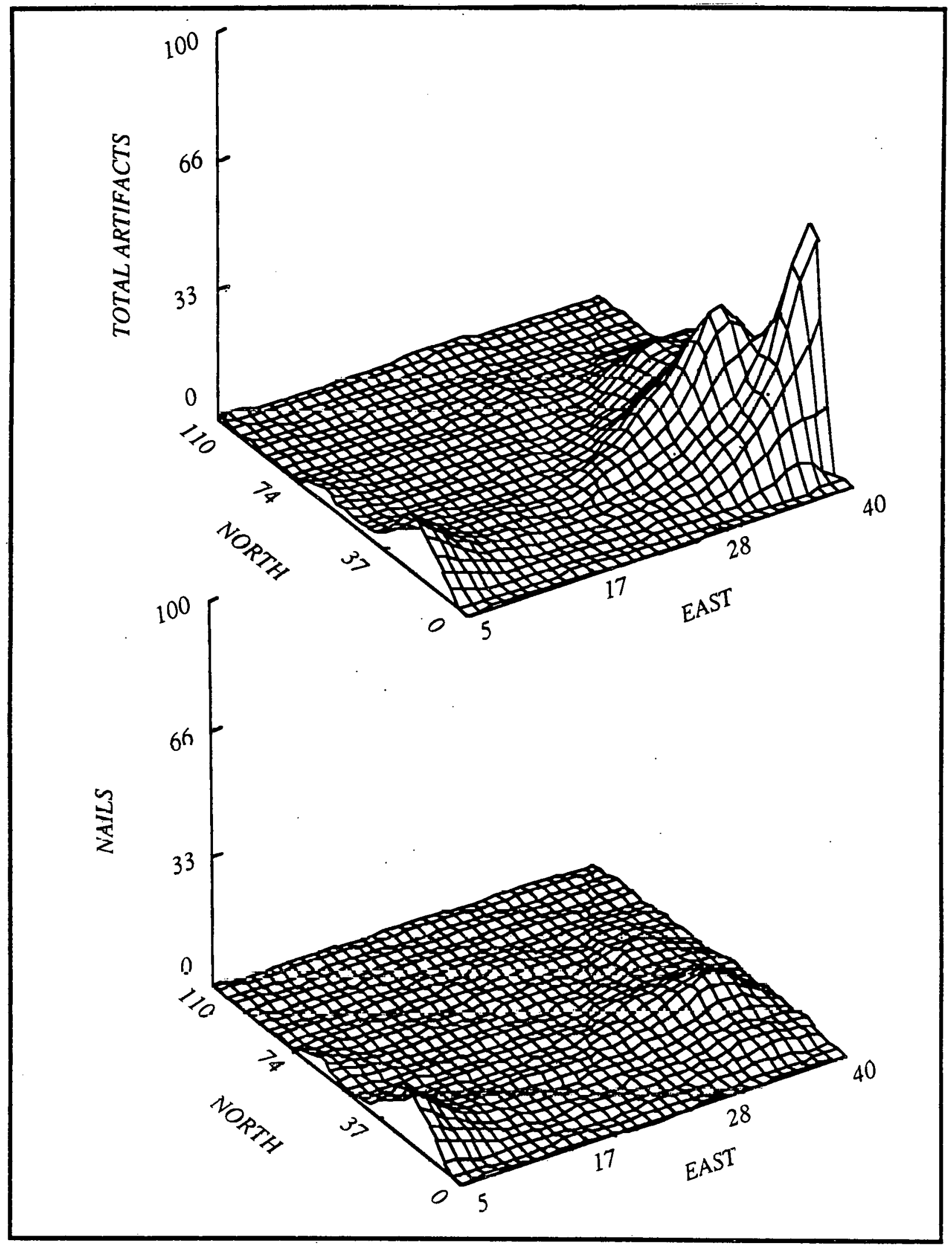

FIGURE 15. Artifact Distribution, Site 16CU205, Shown by Smoothed, Locally Weighted Three-Dimensional Surface Plots. Top View Shows Total Artifacts. Bottom View Shows Nails. 
TABLE 1. DISTRIBUTION OF ARTIFACTS BY CLASS, SITE 16CU205.

\begin{tabular}{|c|c|c|c|c|c|c|c|c|c|c|}
\hline PROVENIENCE & CERAMICS & $\begin{array}{c}\text { CURVED } \\
\text { GLASS }\end{array}$ & $\begin{array}{l}\text { FLAT } \\
\text { GLASS } \\
\end{array}$ & NAILS & $\begin{array}{r}\text { OTHER } \\
\text { ARCHIT. } \\
\end{array}$ & $\begin{array}{c}\text { MISC. } \\
\text { METAL } \\
\end{array}$ & BONE & SHELL & OTHER & TOTALS \\
\hline $\begin{array}{l}\text { N25/E5 } \\
\text { N65/E5 }\end{array}$ & & & & $\begin{array}{c}23 \\
4\end{array}$ & & & & & & $\begin{array}{r}23 \\
4\end{array}$ \\
\hline N20/E10 & & & & 5 & & & & & & 5 \\
\hline N30/E10 & & & & & & 1 & & & & 1 \\
\hline N40/E10 & 1 & & & 1 & & 1 & & & & 3 \\
\hline N25/E15 & & & & 3 & & & & & & 3 \\
\hline N65/E15 & & & & 1 & & & & & & 1 \\
\hline $\mathrm{N} 50 / \mathrm{E} 20$ & & & & & 1 & & & & & 1 \\
\hline N60/E20 & 2 & 1 & & & & & & & & 3 \\
\hline N15/E25 & & 1 & & 1 & & & 1 & & & 3 \\
\hline N25/E25 & & & & & 1 & & & & & 1 \\
\hline N35/E25 & & 5 & 1 & 3 & & & & & & 9 \\
\hline N75/E25 & & & & 3 & 2 & & & & & 5. \\
\hline N85/E25 & 1 & & & & & & & & & 1 \\
\hline N105/E25 & & 2 & & & & & & & & 2 \\
\hline N30/E30 & & 2 & 1 & 1 & & & & & & 4 \\
\hline $\mathrm{N} 40 / \mathrm{E} 30$ & 2 & 2 & 4 & 8 & & 8 & & & & 24 \\
\hline N50/E30 & & & & 2 & & & & & & 2 \\
\hline N60/E30 & & & & & & 2 & & & 1 & 3 \\
\hline N90/E30 & 1 & & & & & & & & & 1 \\
\hline N15/E35 & & 10 & 1 & 6 & & 4 & & . & 1 & 22 \\
\hline N25/E35 & & 4 & & & & & & & & 4 \\
\hline N35/E35 & 4 & 20 & 6 & 19 & 2 & 11 & & & & 62 \\
\hline N45/E35 & 3 & 3 & & 5 & & 4 & & & & 15 \\
\hline N55/E35 & & 3 & & 1 & & 7 & & & & 11 \\
\hline N65/E35 & & 6 & & 8 & & 4 & & 1 & & 19 \\
\hline N75/E35 & 1 & & & 1 & & & & & & 2 \\
\hline N20/E40 & 5 & 73 & & 3 & 5 & 4 & 7 & 2 & 1 & 100 \\
\hline $\mathrm{N} 40 / \mathrm{E} 40$ & 6 & 5 & & 1 & & & & & 1 & 13 \\
\hline N60/E40 & 3 & 2 & & & & & & 3 & & 8 \\
\hline N70/E40 & 1 & 6 & & & 1 & 1 & & 4 & & $1 \cdot 3$ \\
\hline TR. I, STP 26 & 1 & & & & & & & & & 1 \\
\hline TR. I, STP 28 & & 1 & . & & & & & & & 1 \\
\hline TR. J, STP 27 & & 1 & . & & & & & & & 1 \\
\hline TOTALS & 31 & 147 & 13 & 99 & 12 & 47 & 8 & 10 & 4 & 371 \\
\hline
\end{tabular}


TABLE 2. CERAMIC INVENTORY, SITE 16CU205

WARE

SHERD COUNT

VESSEL TYPE AND NUMBER

\section{Refined Earthenware}

Whiteware/Ironstone

$\begin{array}{lll}\text { plain, body } & 9 & \text { indeterminate vessel } \\ \text { plain, rim } & 4 & \text { cup (1), plate (1), unid. (1) } \\ \text { plain, footring } & 2 & \text { [counted w/ rims] } \\ \text { emhnsse,, rim } & 5 & \text { plate (1), bowl (1), unid. (1) } \\ \text { transfer printed, flow-blue, rim } & 1 & \text { unid. (1) } \\ \text { brown band underglaze, body } & 1 & \text { indeterminate vessel } \\ \text { polychrome decal underglaze, body } & 1 & \text { indeterminate vessel }\end{array}$

Yellow ware

plain, rim

brown glazed, body

1 bowl (1)

1 bowl (1)

Stoneware

clear glaze on gray paste, base clear glaze on gray paste, body brown salt glazed int.\&ext., body

2 possible crock (2)

part of crock

indeterminate vessel

Porcelain

plnin, rim

1

unid. (1)

TOTALS

SHERDS: 31

VESSELS:

12

\section{CERAMIC DATES}

Whiteware/Ironstone

Whiteware, underglaze decal

Whiteware, flow blue transfer printed

Yellow ware

Stoneware, clear glazed

Stoneware, brown salt glazed post- 1820

post- 1897

$1840-1910$

1827-1940

post- 1880

late 1800 s-early 1900 s 
TABLE 3. GLASS INVENTORY, SITE 16CU205.

DESCRIPTION SHERD COUNT SESSEL TYPE AND NUMBER

Clear

$\begin{array}{lr}\text { rim } & 8 \\ \text { body } & 95 \\ \text { body, painted } & 8 \\ \text { base } & 6 \\ \text { base, frosted } & 1\end{array}$

8 decorative (1); jar (3); bottle (3)

95

8

6

Amethyst

body

$8 \quad$ unid. (1)

Cobalt

body

3

unid. (1)

Medium Blue

body

1 unid. (1)

Aqua

rim

body

1
4

Blue Tint

body, embossed $\quad 1 \quad$ [may be part of aqua jar]

Brown

body

body, molded

3 bottle (1)

5

Milk Glass

body

body, molded

$1 \quad$ decorative (1)

Flat

green tint 2

blue tint 10

clear

1

TOTALS

SHERDS: 160

VESSELS: 16

\section{GLASS DATES}

Aqua Jar made in blow-back mold Automatic machine-made bottles and jars Amethyst glass

Base with Owens-Illinois Glass Co. Mark Base with Owens-Illinois Glass Co. Mark source: Toulouse 1972

c. 1850 - c. 1920

post- 1903

1880-1915

1929-1954

post- 1954 


\section{DISCUSSION OF RESEARCH RESULTS}

Primarily because of the scarcity of sites within the project ROW, this survey provides little new information pertinent to the research objectives outlined in Chapter IV. Indeed, the total absence of prehistoric sites and historic sites of appreciable age severely limits discussion of any of the proposed research questions. A brief review of the research questions posed for the project is included in the following paragraphs.

1) What is the overall distribution of prehistoric sites in the project area and surrounding vicinity?

Since no aboriginal sites were identified during the survey, no additional information concerning prehistoric settlement patterns has been gained from this project. Virtually all previously recorded aboriginal sites in the ROW vicinity have been recorded along the margins of stream channels and lakes. While the ROW crosses a number of stream channels, no evidence for prehistoric settlement was found in these areas. The minor bayous in the north end of the ROW were probably too small to be used for prehistoric settlement, while the lack of high banks along Bayou Choupique and Kelso Bayou may have made these areas unsuitable for prehistoric habitation.

2) Are there any apparent differences in the settlement pattern during the various periods of prehistoric occupation?

Again, the lack of prehistoric sites within the ROW has limited the extent to which this question can be addressed. As indicated in regional syntheses (e.g., Smith et al. 1983; Neuman 1984), the ROW is peripheral to many of the prehistoric cultures that developed in the Mississipi Valley, and there is little evidence that the local settlement and subsistence pattern was altered significantly by the development of Poverty Point, Marksville, Coles Creek, Troyville, Plaquemine, and Mississippian cultures.

3) What types of natural resources were exploited in the study area during the various periods of prehistoric occupation?

Virtually all of the known prehistoric sites in the ROW vicinity are shell middens that consist primarily of Rangia cuneata. The coastal habitat also would have provided a rich diversity of mammalian fauna, waterfowl, reptiles, amphibians, fish, nutmeats, and wild flora, as well as other molluscan species. These resources would have provided an ample subsistence base for the hunter-gatherer cultures which seem to have persisted in the ROW throughout the prehistoric period. Aside from subsistence resources, the study area provided abundant resources for fuel, shelter, cordage, pottery manufacture, etc. Lithic resources suitable for stone tool manufacture are absent from the ROW vicinity, and these items would have been obtained from non-local sources.

4) Do the prehistoric sites in the study area exhibit emphasis on exploitation of seasonally available resources, or is there evidence of year-round habitation?

This question would require recovery of well-preserved subsistence data from a number of prehistoric sites; lacking this, one must speculate or draw from published information from other projects that pertain to the present ROW. There is no evidence that the aboriginal villages or towns occupied on a year round basis existed in the ROW vicinity, and it is most likely that a pattern of seasonally occupied camps or small villages persisted in this area through the protohistoric period. Many of the most important food resources, such as Rangia cuneata and deer, were most efficiently 
exploited in a particular season; and there is no evidence that agriculture ever assumed a dominant role in the local subsistence pattern.

5) How have the archaeological resources in the study area been affected by various historic land uses (agriculture, dredging of waterways, and residential, commercial, and industrial development?

The major landscape-altering activities that have occurred during the historic period that are likely to have destroyed archaeological resources are oil and gas exploration and extraction, agriculture, residential development, and improvement of drainage and navigation channels. There is no evidence that any of these activities have disturbed archaeological resources within the ROW. Oil and gas exploration and extraction have caused the most widespread disturbances to the landscape, particularly along Bayou Choupique and the marsh land immediately north of Hackberry Island. There are also numerous gas and oil pipelines throughout the ROW and the immediately adjacent area. Agricultural practices such as land leveling and cultivation may also destroy archaeological sites. But there is little evidence that agricultural activities have caused extensive loss of archaeological resources in the ROW vicinity, since most of the local farm land is used for cattle grazing. Navigation channel and drainage improvements have disturbed the natural landscape within the ROW, but there is no evidence within the ROW that archaeological sites have been disturbed by these activities. In the surrounding vicinity, channel modification of the Calcasieu River may have destroyed some prehistoric sites. Residential development along the ROW is quite sparse and does not appear to have resulted in any loss of archaeological resources.

6) What is the nature of the earliest historic occupation, i.e., where are the initial historic occupations located and what was the economic basis for the region's initial settlement?

The field survey did not result in the identification of any historic resources that dated prior to the late nineteenth century. The initial European and American settlements in the ROW vicinity were located along major waterways, such as the Calcasieu River, which afforded a means to transport furs, lumber, naval stores, and agricultural commodities out of the area. 


\section{RECOMMENDATIONS}

The background research and field survey have not produced any evidence that construction of the Texoma Distribution Enhancements Project will result in a significant loss of archaeological or architectural resources. While a number of high potential areas for prehistoric sites were predicted within the ROW, no prehistoric sites were identified in these or other portions of the ROW.

One historic archaeological site, 16CU205, was identified during the field survey. An assortment of domestic and architectural material was recovered from the site, suggesting the presence of a house and possibly one outbuiding within the ROW. The assemblage appears to be most representative of a twentieth-century occupation, although there is some possibility that its earliest occupation occurred in the late nineteenth century. The available information suggests that the site represents a small farmstead or rural residence occupied until the mid-twentieth century. The site is therefore assignable to the "Industrialization and Modernization (1890-1940)" Cultural Unit (Smith et al. 1983).

Twentieth-century farmsteads or rural residences are a common site type, and they have been relatively overlooked by archaeologists and historic preservation planners, primarily because of their abundance and recent age. Since site 16CU205 lacks significant historical association, it must be evaluated primarily on the basis of its archaeological integrity and ability to furnish important historical information.

There was no surface or subsurface evidence that intact features are present at the site, and the artifact deposits were recovered from a generalized sheet refuse context. This type of context is quite common at rural sites, and it is usually characterized by a mixture of materials deposited throughout the site's occupation. In most cases, it is impossible to isolate discrete strata that may be assignable to a particular phase or short interval of a site's occupation; these deposits would normally be found only in closed feature contexts, such as filled wells, trash pits, or privies. Thus, while the site appears relatively undisturbed, the associated materials are limited to a context type that may provide information pertinent only to the spatial patterning of activities.

Research and preservation goals for the Industrialization and Modernization Cultural Unit are provided in the Louisiana Comprehensive Archaeological Plan (Smith et al. 1983:286-288). If it possessed sufficient integrity, Site 16CU205 might provide information pertinent to one research goal:

5. Examine the material changes in the household relating from man's invention of mass-produced machinery at the turn of the century. For instance, how did the automatic bottle-making machine affect the early twentieth-century household? What changes occurred with the introduction of plastic in the $1920 \mathrm{~s}$ and 1930s (Smith et al. 1983:286).

At a minumum, addressing this research question would require well preserved artifact deposits from contexts assignable to discrete periods of the site's occupation, in order to examine the household's consumption and discard patterns throughout the period of occupation. Lacking "microstratigraphy" within the yard refuse and the absence of sealed features, Site 16CU205 fails to meet the minimum data requirements for this research question. It is therefore concluded that Site 16CU205 is ineligible for inclusion in the National Register of Historic Places. 
Construction of the proposed pipeline will partially destroy Site 16CU205. It is impossible to state exactly what fraction of the site will be destroyed, since the sheet refuse deposits extend beyond the ROW limits. The major artifact concentration, interpreted as the house location, is along the eastern margin of the ROW and within the temporary construction easement, so that the pipeline trench will not impact this area; the house location may, however, be disturbed by clearing or movement of construction machinery. The secondary artifact concentration, interpreted as an outbuilding location, is within the permanent easement, and it may be destroyed by clearing or pipeline trench construction.

Given the limited research potential of the site, and the fact that the proposed construction will result in only a partial loss of the site, mitigation of the constuction impacts is not considered appropriate.

In addition to Site 16CU205, a number of historic isolated find spots and a trash dump were identified.within the ROW. The isolated finds are considered to be of no cultural significance, and their loss is acceptable. The trash deposit located on Tract 210 (Survey Area 1) contained recent material; its location on a vacant property adjacent to several currently occupied residences suggests that it is attributable to recent dumping activity. It was not formally recorded as a site, and it is not considered eligible for the National Register, because of its recent age and uncertain origin.

Four standing structures were also identified within the ROW. These were all farm outbuildings less than 40 years of age that lacked architectural distinction or historical association. They are not considered eligible for the National Register, and their destruction will not represent a significant cultural loss. 


\section{REFERENCES CITED}

Bonner, Jack Charles

1972 Pimple Mound Occupation in Southwest Louisiana. Paper presented at the Louisiana Academy of Sciences, Baton Rouge.

Calhoun, James

1984 Louisiana Almanac, 1984-85. Pelican Publishing Co., Gretna, Louisiana.

Ellender, Allie

n.d. A Brief History of Calcasieu Parish. Ms on file, McNeese University Archives, Lake Charles, Louisiana.

Frank, Joseph V., III

1982 A Cultural Kesources Survey of the Bayou Choupique -- Channel Modifications, Lower Reaches. Prepared for Gravity Drainage District No. 4, Calcasieu Parish, Louisiana.

Gagliano, Sherwood M., Richard Weinstein and Eileen K. Burden

1975 Archaeological Investigations Along the Gulf Intracoastal Waterway: Coastal Louisiand Area. Prepared for the U. S. Anny Curps of Engineers, New Orlearls District by Coastal Environments, Inc., Baton Rouge.

Goodyear, Albert C., L. Mark Raab and Timothy C. Klinger

1978 The Status of Archaeological Research Design in Cultural Resource Management. American Antiquity 43:159-173.

Hollister, Archie $S$.

1952 The Geography of Cameron Parish. Ms on file, McNeese University Archives, Lake Charles, Louisiana.

Howe, Henry V., Richard J. Russell, James H. McGuirt, Benjamin C. Kraft and Morton B. Stephenson

1935 Reports on the Geology of Cameron and Vermilion Parishes. Louisiana Geological Survey Geological Bulletin No. 6. New Orleans.

Jones, Paul H., A. N.Turcan, Jr. and Herbert E. Skibitzke

1954 Geology and Ground Water Resources of Southwestern Louisiana. Louisiana Geological Survey Geological Bulletin No. 30. Baton Rouge.

Kniffen, Fred B., Hiram F. Gregory, and George A. Stokes

1987 The Historic Indian Tribes of Louisiana: From 1542 to the Present. Louisiana State University Press, Baton Rouge.

Neuman, Robert W.

1984 An Introduction to Louisiana Archaeology. Louisiana State University Press, Baton Rouge. 
Perrin, William H., editor

1971 Southwest Louisiana Biographical and Historical. Claitor's Publishing Division, Baton Rouge. Reprint of 1891 edition.

Post, Lauren C.

1962a Cajun Sketches From the Prairies of Southwest Louisiana. Louisiana State University Press, Baton Rouge .

1962b Some Notes on the Attakapas Indians of Southwest Louisiana. Louisiana History $3(3): 221-242$.

Raab, L. Mark and Timothy C. Klinger

1977 A Critical Appraisal of "Significance" in Contract Archaeology: American Antiquity 42:629-634.

Smith, Steven D., Philip D. Rivet, Kathleen M. Byrd and Nancy W. Hawkins

1983 Louisiana's Comprehensive Archaeological Plan. State of Louisiana, Department of Culture, Recreation and Tourism, Office of Cultural Development, Division of Archaeology, Baton Rouge.

Swanton, John R.

1979 The Indians of the Southeastern United States. Smithsonian Institution, Bureau of American Ethnology Bulletin 137. Washington, D.C. Reprint of the 1946 edition.

Toth, Alan

1979 The Marksville Connection. In Hopewell Archaeology: The Chillicothe Conference. David S. Brose and N'omi Greber, editors. Kent State University Press, Kent, Ohio. Pp. 188-199.

Toulouse, Julian $\mathrm{H}$.

1972 Bottlemakers and Their Marks. Thomas Nelson, Inc., New York.

Ulmer, Grace

1935 Economic and Social Developments of Calcasieu Parish, Louisiana, 1840-1912. Unpublished M.A. Thesis, History Department, Louisiana State University and Agricultural and Mechanical College.

U. S. Department of Agriculture

1969 General Soil Map, Calcasieu Parish, Louisiana. U. S. Department of Agriculture, Soil Conservation Service, Alexandria, Louisiana.

1971 General Soil Map, Cameron Parish, Louisiana. U. S. Department of Agriculture, Soil Conservation Service, Alexandria, Louisiana.

U. S. Geological Survey

1932 West Lake Quadrangle. U. S. Geological Survey. Scale 1:24,000.

1955 Moss Lake Quadrangle. U. S. Geological Survey. Scale 1:24,000. 
Webb, Clarence $\mathrm{H}$.

1977 The Poverty Point Culture. Geoscience and Man 17. Louisiana State University, Baton Rouge.

Weinstein, Richard A., Eileeen K. Burden and Joseph V. Frank

1977 Cultural Resource Survey of the West Hackberry Strategic Oil-Storage Facility, Cameron Parish, Louisiana. Prepared for the U.S. Department of Energy by Coastal Environments, Inc., Baton Rouge.

Weinstein, Richard A., Eileen K. Burden, Joseph V. Frank and Melanie Thigpen

1979 Updated Cultural Resource Survey of the West Hackberry Strategic Oil-Facility,

Cameron Parish, Louisiana. Prepared for Parsons-Gilbane by Coastal

Environments, Inc., Baton Rouge. 
APPENDIX A

SHOVEL TEST TABLE--SURVEY TRANSECTS

$\Lambda-1$ 


\begin{tabular}{|c|c|c|c|c|c|c|c|}
\hline $\begin{array}{c}\text { SURVEY } \\
\text { AREA }\end{array}$ & TRANSECT & $\begin{array}{l}\text { SHOVEL } \\
\text { TEST NO. }\end{array}$ & $\begin{array}{l}\text { STRATUM/ } \\
\text { LEVEL }\end{array}$ & $\begin{array}{c}\text { DEPTH } \\
(\mathrm{cm})\end{array}$ & $\begin{array}{c}\text { SOIL } \\
\text { COLOR }\end{array}$ & $\begin{array}{c}\text { SOIL } \\
\text { TEXTURE }\end{array}$ & INCLUSIONS \\
\hline 1 & $\bar{A}$ & 1 & 1 & $0-30$ & 10YR $3 / 3$ & sicl & $\overline{\mathrm{NCM}}$ \\
\hline 1 & A & 2 & 1 & $0-40$ & 10 YR $3 / 3$ & mixed fills & $\mathrm{NCM}$ \\
\hline 1 & A & 3 & 1 & $0-30$ & $10 \mathrm{YR} 4 / 2$ & sil & $\mathrm{NCM}$ \\
\hline 1 & A & 4 & 1 & $0-20$ & 10YR $5 / 2$ & sil & NCM \\
\hline 1 & A & 4 & 2 & $20-35$ & 10YR $5 / 4$ & sil & $\mathrm{NCM}$ \\
\hline 1 & A & 6 & 1 & $0-34$ & $10 Y R 4 / 3$ & sil & NCM \\
\hline 1 & A & 7 & 1 & $0-30$ & 10YR $3 / 2$ & sil & NCM \\
\hline 1 & A & 8 & 1 & $0-18$ & $10 Y R 3 / 2$ & sicl & $\mathrm{NCM}$ \\
\hline 1 & A & 8 & 2 & $18-40$ & $10 \mathrm{YR} 6 / 2$ & scl & $\mathrm{NCM}$ \\
\hline 1 & B & 1 & 1 & $0-30$ & $10 \mathrm{YR} 4 / 2$ & scl & NCM \\
\hline 1 & B & 2 & 1 & $0-12$ & 10 YR $3 / 2$ & scl & $\mathrm{NCM}$ \\
\hline 1 & B & 2 & 2 & $12-35$ & 10 YR $5 / 2$ & cl & $\mathrm{NCM}$ \\
\hline 1 & B & 3 & 1 & $0-35$ & $10 Y R \quad 3 / 2$ & scl & $\mathrm{NCM}$ \\
\hline 1 & B & 4 & 1 & $0-23$ & $10 Y R 3 / 2$ & scl & NC.M \\
\hline 1 & B & 4 & 2 & $23-35$ & $10 Y R 4 / 2$ & scl & NCM \\
\hline 1 & B & 5 & 1 & $0-35$ & $10 \mathrm{YR} 4 / 3$ & scl & NCM \\
\hline 1 & B & 6 & 1 & $0-40$ & 10YR $3 / 2$ & scl & NCM \\
\hline 1 & B & 7 & 1 & $0-32$ & 10YR $3 / 2$ & scl & NCM \\
\hline 1 & B & 8 & 1 & $0-30$ & 10YR $3 / 2$ & scl & NCM \\
\hline 1 & B & 8 & 2 & $30-45$ & 10YR $3 / 2$ & scl & NCM \\
\hline 1 & $\mathrm{C}$ & 1 & 1 & $0-12$ & $10 \mathrm{YR} 4 / 3$ & 1 & NCM \\
\hline 1 & C & 1 & 2 & $12-40$ & 10YR $4 / 3$ & mixed fills & $\mathrm{NCM}$ \\
\hline 1 & C & 2 & 1 & $0-33$ & $10 Y R \quad 4 / 2$ & sl & $\mathrm{NCM}$ \\
\hline 1 & D & 1 & 1 & 0.40 & 10 YR $4 / 2$ & scl & $\mathrm{NCM}$ \\
\hline 1 & D & 2 & 1 & $0-35$ & 10YR $3 / 2$ & scl & NCM \\
\hline 1 & E & 1 & 1 & $0-15$ & $10 \mathrm{YR} 4 / 2$ & sl & $\mathrm{NCM}$ \\
\hline 1 & $\mathrm{E}$ & 1 & 2 & $15-30$ & 10YR $6 / 2$ & c & $\mathrm{NCM}$ \\
\hline 1 & E & 2 & 1 & $0-35$ & $10 \mathrm{YR} 5 / 2$ & sl & NCM \\
\hline 1 & $\mathrm{~F}$ & 1 & 1 & $0-15$ & 10YR $3 / 2$ & scl & NCM \\
\hline 1 & F & 1 & 2 & $15-30$ & 10YR 3/2 & mottled scl & $\mathrm{NCM}$ \\
\hline 1 & F & 2 & 1 & $0-40$ & $10 \mathrm{YR} 3 / 2$ & mottled scil & NCM \\
\hline 1 & G & 1 & 1 & 0.15 & 10YR $4 / 2$ & sil & $\mathrm{NCM}$ \\
\hline 1 & G & 1 & 2 & $15-33$ & $10 \mathrm{YR} 5 / 2$ & sil & NCiM \\
\hline 1 & G & 2 & 1 & $0-33$ & $10 Y R 5 / 2$ & sil & NCM \\
\hline 1 & G & 4 & 1 & $0-36$ & $10 Y R 2 / 2$ & sil & NCM \\
\hline 1 & G & 5 & 1 & $0-33$ & 10YR $5 / 2$ & sil & $\mathrm{NCM}$ \\
\hline 1 & $G$ & 6 & 1 & $0-36$ & 10YR 4/2 & sil & $\mathrm{NCM}$ \\
\hline 1 & G & 7 & 1 & $0-43$ & $10 Y R 3 / 3$ & sil & NCM \\
\hline 1 & G & 8 & 1 & $0-38$ & $10 \mathrm{YR} 3 / 3$ & sil & NC.M \\
\hline 1 & 0 & 9 & I & $0-15$ & $10 \mathrm{YR} 7 / 2$ & mottled c & $\mathrm{NCM}$ \\
\hline 1 & $\mathrm{G}$ & 9 & 2 & $15-40$ & $10 Y R 4 / 3$ & sil & NCM \\
\hline 1 & $\mathrm{G}$ & 10 & 1 & $0-23$ & 10YR $7 / 3$ & mottled c & $\mathrm{NCM}$ \\
\hline 1 & $\mathrm{G}$ & 11 & 1 & 0.32 & $10 \mathrm{YR} 5 / 4$ & mixed fills & NCM \\
\hline 1 & G & 12 & 1 & $0-38$ & $10 Y R 3 / 3$ & sil & $\mathrm{NCM}$ \\
\hline 1 & G & 13 & 1 & $0-19$ & 10YR 3/1 & sil & $\mathrm{NCM}$ \\
\hline 1 & $\mathbf{G}$ & 13 & 2 & $19-38$ & 10YR $3 / 2$ & sil & $\mathrm{NCM}$ \\
\hline 1 & G & 14 & 1 & $0-40$ & $10 \mathrm{YR} 3 / 2$ & sil & NCM \\
\hline 1 & G & 15 & 1 & $0-38$ & 1UYR $3 / 2$ & sil & $\mathrm{NCM}$ \\
\hline 1 & G & 16 & 1 & $0-30$ & $10 \mathrm{YR} 5 / 2$ & sil & $\mathrm{NCM}$ \\
\hline 1 & G & 17 & 1 & $0-45$ & $10 \mathrm{YR} 3 / 2$ & sil & NCM \\
\hline 1 & G & 18 & 1 & $0-33$ & $10 Y R 5 / 2$ & sil & $\mathrm{NCM}$ \\
\hline 1 & G & 19 & 1 & $0-36$ & 10YR $6 / 1$ & sicl & $\mathrm{NCM}$ \\
\hline
\end{tabular}




\begin{tabular}{|c|c|c|c|c|c|c|c|}
\hline $\begin{array}{c}\text { SURVEY } \\
\text { AREA } \\
\end{array}$ & TRANSECT & $\begin{array}{l}\text { SHOVEL } \\
\text { TEST NO. }\end{array}$ & $\begin{array}{l}\text { STRATUM/ } \\
\text { LEVEL }\end{array}$ & $\begin{array}{l}\text { DEPTH } \\
(\mathrm{cm})\end{array}$ & $\begin{array}{c}\text { SOIL } \\
\text { COLOR }\end{array}$ & $\begin{array}{c}\text { SOIL } \\
\text { TEXTURE }\end{array}$ & INCLUSIONS \\
\hline 1 & G & 20 & 1 & $0-35$ & $10 \mathrm{YR} 4 / 2$ & sil & NCM \\
\hline 1 & $\mathrm{H}$ & 1 & 1 & $0-35$ & 10YR 3/2 & scl & NCM \\
\hline 1 . & $\mathrm{H}$ & 2 & 1 & $0-40$ & $10 \mathrm{YR} 6 / 2$ & sil & NCM \\
\hline 1 & $\mathrm{H}$ & 3 & 1 & $0-35$ & 10YR 5/2 & $\mathrm{cl}$ & NCM \\
\hline 1 & $\mathrm{H}$ & 4 & 1 & $0-45$ & 10YR $5 / 2$ & $\mathrm{cl}$ & NCM \\
\hline 1 & $\mathrm{H}$ & 5 & 1 & $0-35$ & 10YR 5/2 & $\mathrm{cl}$ & NCM \\
\hline 1 & $\mathrm{H}$ & 6 & 1 & $0-35$ & 10YR $2 / 2$ & sil & NCM \\
\hline 1 & $\mathrm{H}$ & 7 & 1 & $0-40$ & 10YR $3 / 2$ & 1 & NCM \\
\hline 1 & $\mathrm{H}$ & 8 & 1 & $0-40$ & 10YR $3 / 2$ & si & $\mathrm{NCM}$ \\
\hline 1 & $\mathrm{H}$ & 9 & 1 & $0-30$ & $10 Y R 3 / 3$ & sil & NCM \\
\hline 1 & $\mathrm{H}$ & 10 & 1 & $0-22$ & $10 \mathrm{YR} 5 / 4$ & c & NCM \\
\hline 1 & . $\mathrm{H}$ & 10 & 2 & $22-30$ & $10 Y R 5 / 3$ & si & NCM \\
\hline 1 & $\mathrm{H}$ & 11 & 1 & $0-30$ & $10 Y R 5 / 4$ & c & NCM \\
\hline 1 & $\mathrm{H}$ & 12 & 1 & $0-2$ & $10 Y R \quad 6 / 2$ & $s$ & NCM \\
\hline 1 & $\mathrm{H}$ & 13 & 1 & $2-35$ & $10 Y R 4 / 2$ & si & NCM \\
\hline 1 & $\mathrm{H}$ & 13 & 1 & $0-40$ & $10 \mathrm{YR} 2 / 2$ & sil & NCM \\
\hline 1 & $\mathrm{H}$ & 14 & 1 & $0-26$ & 10YR $2 / 2$ & sil & NCM \\
\hline 1 & $\mathrm{H}$ & 14 & 2 & $26-40$ & 10YR $4 / 2$ & sil & NCM \\
\hline 1 & $\mathrm{H}$ & 15 & 1 & $0-18$ & 10YR 2/2 & sil & NCM \\
\hline 1 & $\mathrm{H}$ & 15 & 2 & $18-40$ & $10 \mathrm{YR} 4 / 2$ & sil & NCM \\
\hline 1 & $\mathrm{H}$ & 16 & 1 & $0-35$ & $10 \mathrm{YR} 4 / 2$ & $\mathrm{cl}$ & $\mathrm{NCM}$ \\
\hline 1 & $\mathrm{H}$ & 17 & 1 & $0-8$ & $10 \mathrm{YR} 2 / 2$ & sil & NCM \\
\hline 1 & $\mathrm{H}$ & 17 & 2 & $8-35$ & $10 \mathrm{YR} 5 / 2$ & $\mathrm{cl}$ & NCM \\
\hline 1 & $\mathrm{H}$ & 18 & 1 & $0-35$ & 10YR $3 / 2$ & $\mathrm{cl}$ & $\mathrm{NCM}$ \\
\hline 1 & $\mathrm{H}$ & 19 & 1 & $0-35$ & $10 \mathrm{YR} 3 / 2$ & $\mathrm{cl}$ & NCM \\
\hline 1 & I & 1 & 1 & $0-40$ & $10 Y R 3 / 2$ & sl & NCM \\
\hline 1 & I & 2 & 1 & $0-35$ & $10 \mathrm{YR} 2 / 2$ & $\mathrm{cl}$ & $\mathrm{NCM}$ \\
\hline 1 & I & 3 & 1 & $0-35$ & $10 \mathrm{YR} 5 / 1$ & $\mathrm{cl}$ & NCM \\
\hline 1 & I & 4 & 1 & $0-6$ & 10YR 4/1 & si & NCM \\
\hline 1 & I & 4 & 2 & $6-14$ & 10YR $8 / 2$ & s & NCM \\
\hline 1 & 1 & 4 & 3 & $14-40$ & $10 Y R 2 / 2$ & cl & NCM \\
\hline 1 & I & 5 & 1 & $0-30$ & 10YR 2/1 & cl & NCM \\
\hline 1 & I & 5 & 2 & $30-40$ & $10 Y R 4 / 1$ & cl & $\mathrm{NCM}$ \\
\hline 1 & I & 6 & 1 & $0-40$ & $10 \mathrm{YR} 2 / 2$ & $\mathrm{cl}$ & $\mathrm{NCM}$ \\
\hline 1 & I & 7 & 1 & $0-5$ & $10 \mathrm{YR} 5 / 2$ & si & NCM \\
\hline 1 & I & 7 & 2 & $5-10$ & 10YR $8 / 2$ & $s$ & NCM \\
\hline 1 & I & 7 & 3 & $10-45$ & $10 Y R 5 / 2$ & sicl & NCM \\
\hline 1 & I & 8 & 1 & $0-30$ & 10YR $5 / 2$ & si & NCM \\
\hline 1 & I & 9 & 1 & 0.40 & 10YR $5 / 2$ & si & NCM \\
\hline 1 & I & 10 & 1 & $0-35$ & $10 \mathrm{YR} 3 / 2$ & $\mathrm{cl}$ & NCM \\
\hline 1 & I & 11 & 1 & $0-25$ & $10 Y R 4 / 2$ & si & $\mathrm{NCM}$ \\
\hline 1 & I & 11 & 2 & $25-40$ & 10YR $2 / 2$ & c & NCM \\
\hline 1 & I & 12 & 1 & $0-40$ & 10YR 4/1 & c & NCM \\
\hline 1 & I & 13 & 1 & $0-30$ & $10 \mathrm{YR} 4 / 1$ & mixed fills & NCM \\
\hline 1 & I & 14 & 1 & $0-35$ & $10 \mathrm{YR} 4 / 1$ & mixed fills & NCM \\
\hline 1 & I & 15 & 1 & $0-40$ & 10YR 2/1 & $c$ & NCM \\
\hline 1 & I & 16 & 1 & $0-40$ & 10YR $2 / 1$ & c & NCM \\
\hline 1 & I & 17 & 1 & $0-45$ & 10YR $3 / 2$ & si & NCM \\
\hline 1 & I & 18 & 1 & $0-40$ & $10 \mathrm{YR} 4 / 2$ & si & $\mathrm{NCM}$ \\
\hline 1 & I & 19 & 1 & $0-40$ & $10 \mathrm{YR} 4 / 2$ & si & NCM \\
\hline 1 & I & 20 & 1 & $0-30$ & $10 \mathrm{YR} 4 / 2$ & sil & NCM \\
\hline 1 & $I$ & 21 & 1 & $0-40$ & $10 \mathrm{YR} 5 / 2$ & sicl & NCM \\
\hline
\end{tabular}




\begin{tabular}{|c|c|c|c|c|c|c|c|}
\hline $\begin{array}{c}\text { SURVEY } \\
\text { AREA }\end{array}$ & TRANSECT & $\begin{array}{l}\text { SHOVEL } \\
\text { TEST NO. }\end{array}$ & $\begin{array}{l}\text { STRATUM/ } \\
\text { LEVEL }\end{array}$ & $\begin{array}{c}\text { DEPTH } \\
(\mathrm{cm})\end{array}$ & $\begin{array}{c}\text { SOIL } \\
\text { COLOR }\end{array}$ & $\begin{array}{c}\text { SOIL } \\
\text { TEXTURE }\end{array}$ & INCLUSIONS \\
\hline 1 & $\bar{I}$ & 22 & 1 & $0-40$ & $10 \mathrm{YR} 3 / 2$ & sicl & $\overline{N C M}$ \\
\hline 1 & $I$ & 23 & 1 & $0-40$ & $10 \mathrm{YR} 2 / 2$ & c & NCM \\
\hline 1 & I & 24 & 1 & $0-35$ & $10 \mathrm{YR} 2 / 2$ & c & $\mathrm{NCM}$ \\
\hline 1 & I & 25 & 1 & $0-35$ & $10 Y R 3 / 2$ & sil & $\mathrm{NCM}$ \\
\hline 1 & I & 26 & $n / a$ & surface & & & 1 historic ceramic \\
\hline 1 & I & 26 & 1 & $0-35$ & $10 Y R 3 / 2$ & cl & $\mathrm{NCM}$ \\
\hline 1 & I & 26 & 2 & $35-55$ & $10 Y R 5 / 3$ & sil & $\mathrm{NCM}$ \\
\hline 1 & I & 27 & 1 & $0-32$ & $10 \mathrm{YR} 3 / 2$ & cl & NCM \\
\hline 1 & I & 27 & 2 & $32-40$ & $10 \mathrm{YR} 5 / 3$ & sil & $\mathrm{NCM}$ \\
\hline 1 & I & 28 & 1 & $0-30$ & $10 Y R 4 / 2$ & sil & 1 bottle glass sherd \\
\hline 1 & I & 28 & 2 & $30-50$ & 10YR $4 / 2$ & cl & $\mathrm{NCM}$ \\
\hline $\begin{array}{l}1 \\
1\end{array}$ & I & 29 & 1 & $0-40$ & 10YR $5 / 2$ & si & $\begin{array}{l}\text { brick, bottle glass, } \\
\text { fiber glass, erc. }\end{array}$ \\
\hline 1 & I & 29 & 2 & $40-60$ & $10 Y R 5 / 3$ & sil & NCM \\
\hline 1 & $I$ & 30 & 1 & $0-30$ & $10 \mathrm{YR} 4 / 2$ & sil & NCM \\
\hline 1 & I & 31 & 1 & $0-20$ & $10 \mathrm{YR} 4 / 2$ & sil & NCM \\
\hline 1 & I & 31 & 2 & $20-30$ & $10 \mathrm{YR} 2 / 2$ & c. & NCM \\
\hline 1 & I & 32 & 1 & u-3u & $10 Y R 5 / 2$ & si & $\mathrm{NCM}$ \\
\hline 1 & J & 1 & 1 & $0-35$ & 10YR $3 / 2$ & sil & NCM \\
\hline 1 & $\mathbf{J}$ & 2 & 1 & $0-34$ & $10 Y R 3 / 1$ & sil & NCM \\
\hline 1 & $\mathbf{J}$ & 3 & 1 & $0-40$ & $10 Y R 3 / 2$ & sil & NCM \\
\hline 1 & $\mathrm{~J}$ & 4 & 1 & $0-35$ & $10 Y R 5 / 3$ & sil & $\mathrm{NCM}$ \\
\hline 1 & $\mathrm{~J}$ & 5 & 1 & $0-32$ & $10 \mathrm{YR} 3 / 2$ & sil & NCM \\
\hline 1 & $\mathrm{~J}$ & 6 & 1 & $0-34$ & $10 \mathrm{YR} 3 / 2$ & sil & NCM \\
\hline 1 & $\mathrm{~J}$ & 7 & 1 & $0-33$ & $10 \mathrm{YR} 4 / 2$ & mottled sil & NCM \\
\hline 1 & J & 8 & 1 & $0-33$ & $10 Y R 4 / 3$ & sil & $\mathrm{NCM}$ \\
\hline 1 & $\mathbf{J}$ & 9 & 1 & $0-20$ & $10 \mathrm{YR} 4 / 3$ & sil & NCM \\
\hline 1 & $\mathbf{J}$ & 9 & 2 & $20-37$ & $10 \mathrm{YR} 5 / 3$ & 3il & NCM \\
\hline 1 & J & 10 & 1 & $0-32$ & 10YR 4/2 & sil & NCM \\
\hline 1 & J & 11 & 1 & $0-30$ & 10YR 4/1 & sil & $\mathrm{NCM}$ \\
\hline 1 & I & 12 & 1 & 0.32 & 10YR 1/1 & jicl & $N C M$ \\
\hline 1 & J & 13 & 1 & 0.18 & $10 \mathrm{YR} 4 / 2$ & sicl & NCM \\
\hline 1 & J & 13 & 2 & $18-34$ & 10YR $6 / 2$ & sil & NCM \\
\hline 1 & J & 13 & 3 & $34-40$ & $10 \mathrm{YR} 6 / 3$ & sil & $\mathrm{NCM}$ \\
\hline 1 & $\mathrm{~J}$ & 14 & 1 & $0-33$ & $10 \mathrm{YR} 5 / 2$ & sicl & NCM \\
\hline 1 & $J$ & 15 & 1 & $0-32$ & $10 Y R 4 / 1$ & sicl & NCM \\
\hline 1 & J & 16 & 1 & $0-30$ & 10YR 3/1 & sicl & NCM \\
\hline 1 & J & 17 & 1 & $0-36$ & 10YR $3 / 2$ & sil & NCM \\
\hline 1 & $J$ & 18 & 1 & $0-12$ & $10 \mathrm{YR} 4 / 2$ & sil & $\mathrm{NCM}$ \\
\hline 1 & $\mathbf{J}$ & 18 & 2 & $12-28$ & 10 YR $5 / 2$ & sil & $\mathrm{NCM}$ \\
\hline 1 & J & 18 & 3 & $28-32$ & 10YR $6 / 6$ & sicl & NCM \\
\hline 1 & J & 19 & 1 & $0-31$ & 10YR 4/2 & sil & NCM \\
\hline 1 & J & 20 & 1 & $0-32$ & 10YR 4/1 & sicl & NCM \\
\hline 1 & $\mathbf{J}$ & 21 & 1 & $0-25$ & $10 \mathrm{YR} 4 / 2$ & sil & NCM \\
\hline 1 & $\mathrm{~J}$ & 21 & 2 & $25-38$ & $10 \mathrm{YR} 5 / 2$ & sil & NCM \\
\hline 1 & $J$ & 22 & 1 & $0-35$ & $10 \mathrm{YR} 4 / 2$ & sil & $\mathrm{NCM}$ \\
\hline 1 & $J$ & 23 & 1 & $0-32$ & 10YR 3/1 & $\mathrm{cl}$ & NCM \\
\hline 1 & $J$ & 24 & 1 & $0-14$ & $10 Y R \quad 4 / 2$ & $\mathrm{cl}$ & $\mathrm{NCM}$ \\
\hline 1 & $J$ & 24 & 2 & $14-31$ & 10YR 3/1 & $\mathrm{cl}$ & $\mathrm{NCM}$ \\
\hline 1 & J & 25 & 1 & $0-32$ & 10YR 3/1 & $\mathrm{cl}$ & NCM \\
\hline 1 & $\mathrm{~J}$ & 26 & 1 & $0-34$ & 10YR 4/2 & sicl & $\mathrm{NCM}$ \\
\hline 1 & $\mathrm{~J}$ & 27 & 1 & $0-30$ & $10 \mathrm{YR} 3 / 2$ & sicl & 1 pc clear glass \\
\hline
\end{tabular}




\begin{tabular}{|c|c|c|c|c|c|c|c|}
\hline $\begin{array}{c}\text { SURVEY } \\
\text { AREA }\end{array}$ & TRANSECT & $\begin{array}{c}\text { SHOVEL } \\
\text { TEST NO. }\end{array}$ & $\begin{array}{c}\text { STRATUM/ } \\
\text { LEVEL }\end{array}$ & $\begin{array}{c}\text { DEPTH } \\
(\mathrm{cm})\end{array}$ & $\begin{array}{c}\text { SOIL } \\
\text { COLOR }\end{array}$ & $\begin{array}{c}\text { SOIL } \\
\text { TEXTURE }\end{array}$ & INCLUSIONS \\
\hline 1 & $\mathrm{~J}$ & 27 & 2 & $30-37$ & 10 YR $5 / 3$ & si & $\mathrm{NCM}$ \\
\hline 1 & $\mathrm{~J}$ & 28 & 1 & $0-18$ & $10 Y R 4 / 2$ & sil & $\mathrm{NCM}$ \\
\hline 1 & $\mathrm{~J}$ & 28 & 2 & $18-36$ & $10 \mathrm{YR} 6 / 3$ & si & $\mathrm{NCM}$ \\
\hline 1 & $\mathrm{~J}$ & 29 & 1 & $0-22$ & 10YR $5 / 2$ & sil & $\mathrm{NCM}$ \\
\hline 1 & $\mathrm{~J}$ & 29 & 2 & 22.35 & 10YR $5 / 1$ & sil & $\mathrm{NCM}$ \\
\hline 1 & $\mathrm{~J}$ & 30 & 1 & $0-33$ & $10 \mathrm{YR} 4 / 2$ & sil & NCM \\
\hline 1 & $\mathrm{~J}$ & 31 & 1 & $0-32$ & $10 Y R 4 / 1$ & sicl & $\because \mathrm{NCM}$ \\
\hline 1 & $\mathrm{~J}$ & 32 & 1 & $0-33$ & 10YR $5 / 2$ & mottled sicl & $\mathrm{NCM}$ \\
\hline 1 & $\mathrm{~J}$ & 33 & 1 & $0-30$ & $10 Y R 4 / 1$ & sicl & $\mathrm{NCM}$ \\
\hline 1 & $\mathrm{~K}$ & 1 & 1 & $0-30$ & $10 \mathrm{YR} 4 / 2$ & sicl & $\mathrm{NCM}$ \\
\hline 1 & K & 2 & 1 & $0-14$ & 10 YR $5 / 3$ & sicl & $\mathrm{NCM}$ \\
\hline 1 & K & 2 & 2 & $14-31$ & $10 Y R 4 / 3$ & sicl & $\mathrm{NCM}$ \\
\hline 1 & $\mathbf{K}$ & 3 & 1 . & 0.33 & 10YR $3 / 2$ & sicl & NCM \\
\hline 1 & $\mathrm{~K}$ & 4 & 1 & $0-32$ & $10 \mathrm{YR} 7 / 2$ & sil & $: \mathrm{NCM} \Rightarrow$ \\
\hline 1 & $\mathbf{K}$ & 5 & 1 & $0-30$ & $10 Y R 5 / 5$ & sil & $\mathrm{NCM}$ \\
\hline 1 & K & 6 & 1 & $0-35$ & 10YR $4 / 2$ & sicl & $\mathrm{NCM}$ \\
\hline 1 & K & 7 & 1 & $0-30$ & $10 \mathrm{YR} 3 / 2$ & sil & $\mathrm{NCM}$ \\
\hline 1 & K & 7 & 2 & $30-35$ & 10YR $5 / 2$ & si & NCM \\
\hline 1 & $\mathrm{~K}$ & 8 & 1 & $0-30$ & 10YR $5 / 2$ & sil & $\mathrm{NCM}$ \\
\hline 1 & L & 1 & 1 & $0-30$ & $10 \mathrm{YR} 5 / 2$ & si & $\mathrm{NCM}$ \\
\hline 1 & $\bar{L}$ & 2 & 1 & $0-30$ & $10 \mathrm{YR} 5 / 2$ & si & NCM \\
\hline 1 & $\mathrm{~L}$ & 3 & 1 & $0-40$ & $10 Y R 2 / 2$ & c & $\mathrm{NCM}$ \\
\hline 1 & $\mathrm{~L}$ & 4 & 1 & $0-35$ & 10YR $3 / 2$ & sicl & $\mathrm{NCM}$ \\
\hline 1 & L & 5 & 1 & $0-35$ & $10 \mathrm{YR} 4 / 2$ & sil & $\mathrm{NCM}$ \\
\hline 1 & L & 6 & 1 & $0-30$ & $10 Y R 4 / 2$ & si & NCM \\
\hline 1 & L & 7 & 1 & $0-35$ & 10YR $4 / 2$ & si & $\mathrm{NCM}$ \\
\hline 1 & L & 8 & 1 & $0-35$ & $10 Y R 4 / 2$ & sil & NCM \\
\hline 1 & $\mathbf{M}$ & 1 & 1 & $0-33$ & $10 \mathrm{YR} 4 / 2$ & si & $\mathrm{NCM}$ \\
\hline 1 & $M$ & 2 & 1 & $0-30$ & 10YR 5/1 & $\mathrm{cl}$ & $\mathrm{NCM}$ \\
\hline 1 & M & 3 & 1 & $0-31$ & 10YR $6 / 3$ & cl & $\mathrm{NCM}$ \\
\hline 1 & $\mathbf{M}$ & 4 & 1 & $0-15$ & 10YR $4 / 2$ & $\mathrm{cl}$ & NCM \\
\hline 1 & $\mathbf{M}$ & 4 & 2 & $15-30$ & 10YR $2 / 1$ & c & $\mathrm{NCM}$ \\
\hline 1 & M & 5 & 1 & $0-13$ & 10YR $4 / 2$ & $\mathrm{cl}$ & $\mathrm{NCM}$ \\
\hline 1 & $\mathbf{M}$ & 5 & 2 & $13-32$ & 10YR $3 / 1$ & sicl & $\mathrm{NCM}$ \\
\hline 1 & $\mathbf{M}$ & 6 & 1 & $0-10$ & 10YR $5 / 2$ & sil & $\mathrm{NCM}$ \\
\hline 1 & $\mathrm{M}$ & 6 & 2 & $10-26$ & 10YR 4/1 & $\mathrm{cl}$ & $\mathrm{NCM}$ \\
\hline 1 & $M$ & 6 & 3 & $26-34$ & IOYR $3 / 1$ & c & $\mathrm{NCM}$ \\
\hline 1 & $\mathbf{M}$ & 7 & 1 & $0-11$ & 10YR $3 / 3$ & sil & $\mathrm{NCM}$ \\
\hline 1 & $\mathbf{M}$ & 7 & 2 & $11-17$ & 10 YR $5 / 2$ & sil & $\mathrm{NCM}$ \\
\hline 1 & $M$ & 7 & 3 & $17-33$ & $10 \mathrm{YR} 4 / 1$ & sicl & $\mathrm{NCM}$ \\
\hline 1 & $\mathrm{M}$ & 8 & 1 & $0-15$ & 10YR $3 / 2$ & sil. & NCM \\
\hline 1 & $\mathbf{M}$ & 8 & 2 & $15-34$ & $10 Y R \quad 4 / 3$ & sil & $\mathrm{NCM}$ \\
\hline 1 & $\mathbf{M}$ & 9 & 1 & $0-21$ & $10 \mathrm{YR} 4 / 2$ & sil & $\mathrm{NCM}$ \\
\hline 1 & $\mathbf{M}$ & 9 & 2 & $21-38$ & $10 Y R 4 / 3$ & sil & $\mathrm{NCM}$ \\
\hline 1 & $\mathbf{M}$ & 10 & 1 & $0-9$ & $10 Y R 5 / 2$ & sil & $\mathrm{NCM}$ \\
\hline 1 & $\mathbf{M}$ & 10 & 2 & $9-18$ & $10 Y R \quad 6 / 3$ & sil & $\mathrm{NCM}$ \\
\hline 1 & $\mathbf{M}$ & 10 & 3 & $18-32$ & $10 Y R 4 / 2$ & si & $\mathrm{NCM}$ \\
\hline 1 & $\mathbf{M}$ & 11 & 1 & $0-28$ & $10 Y R 3 / 2$ & sil & $\mathrm{NCM}$ \\
\hline 1 & $\mathbf{M}$ & 11 & 2 & $28-32$ & 10YR $4 / 2$ & sil & NCM \\
\hline 1 & $\mathbf{M}$ & 12 & 1 & $0-33$ & $10 Y R 4 / 2$ & sil & NCM \\
\hline 1 & $\mathbf{M}$ & 13 & 1 & $0-34$ & 10YR $4 / 2$ & sil & NCM \\
\hline 1 & $\mathbf{M}$ & 14 & 1 & 0.32 & $10 \mathrm{YR} 5 / 2$ & sicl & $\mathrm{NCM}$ \\
\hline
\end{tabular}




\begin{tabular}{|c|c|c|c|c|c|c|c|}
\hline $\begin{array}{c}\text { SURVEY } \\
\text { AREA }\end{array}$ & TRANSECT & $\begin{array}{l}\text { SHOVEL } \\
\text { TEST NO. }\end{array}$ & $\begin{array}{l}\text { STRATUM/ } \\
\text { LEVEL }\end{array}$ & $\begin{array}{l}\text { DEPTH } \\
(\mathrm{cm})\end{array}$ & $\begin{array}{c}\text { SOIL } \\
\text { COLOR }\end{array}$ & $\begin{array}{c}\text { SOIL } \\
\text { TEXTURE }\end{array}$ & INCLUSIONS \\
\hline 1 & $\mathbf{M}$ & 15 & 1 & $0-31$ & $10 \mathrm{YR} 5 / 3$ & sicl & $\mathrm{NCM}$ \\
\hline 1 & $\mathbf{M}$ & 16 & 1 & 0.33 & $10 Y R 4 / 2$ & sicl & NCM \\
\hline 1 & $\mathbf{M}$ & 17 & 1 & $0-38$ & $10 Y R 5 / 2$ & sil & $\mathrm{NCM}$ \\
\hline 1 & $\mathbf{M}$ & 18 & 1 & $0-16$ & 10YR $4 / 2$ & sil & $\mathrm{NCM}$ \\
\hline 1 & $\mathbf{M}$ & 18 & 2 & $16-33$ & $10 Y R 5 / 3$ & si & NCM \\
\hline 1 & $\mathbf{M}$ & 19 & 1 & $0-23$ & 10YR 4/2 & sil & $\mathrm{NCM}$ \\
\hline 1 & $\mathbf{M}$ & 19 & 2 & $23-36$ & 10YR 4/2 & sicl & NCM \\
\hline 1 & $\mathbf{M}$ & 20 & 1 & $0-18$ & 10YR 4/2 & sil & NCM \\
\hline 1 & $\mathbf{M}$ & 20 & 2 & $18-32$ & 10YR $6 / 3$ & si & NCM \\
\hline 1 & $\mathbf{M}$ & 21 & 1 & $0-33$ & 10YR 4/2 & sil & $\mathrm{NCM}$ \\
\hline 1 & $\mathbf{M}$ & 22 & 1 & $0-38$ & 10YR $4 / 2$ & sil & NCM \\
\hline 1 & $\mathbf{M}$ & 22 & 1 & $38-40$ & $10 Y R 5 / 2$ & sil & NCM \\
\hline 1 & $\mathbf{M}$ & 23 & $\mathbf{p}$ & $0-22$ & 10YR $4 / 2$ & sil & $\mathrm{NCM}_{\mathrm{I}}$ \\
\hline 1 & $\mathbf{M}$ & 23 & 2 & $22-43$ & 10YR $6 / 2$ & sicl & $\mathrm{NCM}^{\prime}$ \\
\hline 1 & $\mathbf{M}$ & 24 & 1 & $0-32$ & $10 Y R 5 / 2$ & mixed fills & $\mathrm{NCM}$ \\
\hline 1 & $\mathbf{M}$ & 25 & 1 & $0-33$ & 10YR 4/2 & sil & NCM \\
\hline 1 & $\mathbf{N}$ & 1 & 1 & $0-35$ & 10YR $5 / 2$ & sil & NCM \\
\hline 1 & $\mathbf{N}$ & 2 & 1 & $0-30$ & 10YR 3/1 & c & NCM \\
\hline 1 & $\mathbf{N}$ & 3 & 1 & $0-30$ & 10YR 3/1 & c & NCM \\
\hline 1 & $\mathbf{N}$ & 4 & 1 & $0-30$ & 10YR 3/1 & c & NCM \\
\hline 1 & $\mathbf{N}$ & 5 & 1 & $0-30$ & 10YR 3/1 & c & NCM \\
\hline 1 & $\mathbf{N}$ & 6 & 1 & $0-30$ & 10YR 3/1 & c & $\mathrm{NCM}$ \\
\hline 1 & $\mathbf{N}$ & 7 & 1 & $0-30$ & 10YR 5/2 & cl & NCM \\
\hline 1 & $\mathbf{N}$ & 8 & 1 & $0-34$ & 10YR 4/2 & si & NCM \\
\hline 1 & $\mathbf{N}$ & 8 & 2 & $34-45$ & 10YR $5 / 2$ & si & $\mathrm{NCM}$ \\
\hline 1 & $\mathbf{N}$ & 9 & 1 & $0-23$ & 10YR 4/2 & si & NCM \\
\hline 1 & $\mathbf{N}$ & 9 & 2 & $23-40$ & 10YR $5 / 2$ & si & NCM \\
\hline 1 & $\mathbf{N}$ & 10 & 1 & $0-40$ & $10 Y R 4 / 2$ & si & NCM \\
\hline 1 & $\mathbf{N}$ & 11 & 1 & $0-40$ & 10YR $2 / 1$ & c & NCM \\
\hline 1 & $\mathbf{N}$ & 13 & 1 & $0-35$ & 10YR 4/2 & sil & $\mathrm{NCM}$ \\
\hline 1 & $\mathbf{N}$ & 14 & 1 & $0-30$ & 10YR $5 / 1$ & sicl & NCM \\
\hline 1 & is & 15 & 1 & $0-17$ & 10YR $6 / 1$ & sicl & NCM \\
\hline 1 & $\mathbf{N}$ & 15 & 1 & $17-3 n$ & 10YR $5 / 1$ & $s i$ & $\mathrm{NCM}$ \\
\hline 1 & $\mathbf{N}$ & 16 & 1 & $0-35$ & 10YR 4/2 & sil & NCM \\
\hline 1 & $\mathbf{N}$ & 17 & 1 & $0-40$ & 10YR 4/2 & sil & $\mathrm{NCM}$ \\
\hline 1 & $\mathbf{N}$ & 18 & 1 & 0.40 & 10YR 4/2 & sil & NCM \\
\hline 1 & $\mathbf{N}$ & 19 & 1 & $0-35$ & 10YR $3 / 2$ & sil & $\mathrm{NCM}$ \\
\hline 1 & $\mathbf{N}$ & 20 & 1 & $0-13$ & 10YR 4/2 & c & NCM \\
\hline 1 & $\mathbf{N}$ & 20 & 2 & $13-29$ & 10YR $5 / 2$ & si & NCM \\
\hline 1 & n & 20 & 3 & $29-40$ & IOYR $3 / 2$ & si & $\mathrm{NCM}$ \\
\hline 1 & $\mathbf{N}$ & 21 & 1 & $0-30$ & 10YR 5/2 & si & $\mathrm{NCM}$ \\
\hline 1 & $\mathbf{N}$ & 22 & 1 & $0-35$ & 10YR $3 / 2$ & cl & $\mathrm{NCM}$ \\
\hline 1 & $\mathbf{N}$ & 23 & 1 & $0-45$ & 10YR $2 / 2$ & 1 & $\mathrm{NCM}$ \\
\hline 1 & $\mathbf{N}$ & 24 & 1 & $0-40$ & $10 Y R 4 / 2$ & sicl & $\mathrm{NCM}$ \\
\hline 1 & $\mathbf{N}$ & 25 & 1 & $0-40$ & 10YR 3/1 & sicl & $\mathrm{NCM}$ \\
\hline 1 & $\mathbf{P}$ & 1 & 1 & $0-35$ & 10YR 4/2 & sil & $\mathrm{NCM}$ \\
\hline 1 & $\mathbf{P}$ & 2 & 1 & $0-30$ & 10YR $5 / 2$ & si & $\mathrm{NCM}$ \\
\hline 1 & $\mathbf{P}$ & 2 & 2 & $30-40$ & 10YR $6 / 2$ & si & NCM \\
\hline 1 & $\mathbf{P}$ & 3 & 1 & $0-30$ & 10YR $5 / 2$ & si & NCM \\
\hline 1 & P & 4 & 1 & $0-35$ & 10YR 5/2 & sil & NCM \\
\hline 1 & $\mathbf{P}$ & 5 & 1 & $0-30$ & 10YR 5/2 & sil & NCM \\
\hline 1 & $P$ & 6 & 1 & $0-10$ & 10YR 5/2 & sil & $\mathrm{NCM}$ \\
\hline
\end{tabular}




\begin{tabular}{|c|c|c|c|c|c|c|c|}
\hline $\begin{array}{c}\text { SURVEY } \\
\text { AREA }\end{array}$ & TRANSECT & $\begin{array}{l}\text { SHOVEL } \\
\text { TEST NO. }\end{array}$ & $\begin{array}{c}\text { STRATUM/ } \\
\text { LEVEL }\end{array}$ & $\begin{array}{c}\text { DEPTH } \\
(\mathrm{cm})\end{array}$ & $\begin{array}{c}\text { SOIL } \\
\text { COLOR }\end{array}$ & $\begin{array}{c}\text { SOIL } \\
\text { TEXTURE }\end{array}$ & INCLUSIONS \\
\hline 1 & $\bar{P}$ & 6 & 2 & $10-35$ & $10 Y R 5 / 2$ & si & $\overline{\mathrm{NCM}}$ \\
\hline 1 & Q & 1 & 1 & $0-28$ & 10 YR $5 / 4$ & sil & $\mathrm{NCM}$ \\
\hline 1 & $Q$ & 1 & 2 & $28-32$ & $10 \mathrm{YR} 7 / 4$ & sil & $\mathrm{NCM}$ \\
\hline 1 & $\mathbf{Q}$ & 2 & 1 & $0-27$ & $10 \mathrm{YR} 5 / 2$ & sil & NCM \\
\hline 1 & $\mathrm{Q}$ & 2 & 2 & $27-33$ & $10 \mathrm{YR} 6 / 3$ & sil & NCM \\
\hline 1 & $\mathbf{Q}$ & 3 & 1 & $0-23$ & $10 \mathrm{YR} 4 / 2$ & sil & $\mathrm{NCM}$ \\
\hline 1 & $Q$ & 3 & 2 & $23-35$ & $10 \mathrm{YR} 6 / 3$ & si & $\mathrm{NCM}$ \\
\hline 1 & Q & 4 & 1 & $0-20$ & $10 \mathrm{YR} 5 / 3$ & sil & $\mathrm{NCM}$ \\
\hline 1 & Q & 4 & 2 & $20-36$ & $10 \mathrm{YR} 7 / 3$ & sil & NCM \\
\hline 1 & $\mathbf{Q}$ & 5 & l & $0-31$ & IOYR $6 / 4$ & sicl & $\mathrm{NCM}$ \\
\hline 1 & $\mathbf{R}$ & 1 & 1 & $0-18$ & $10 \mathrm{YR} 4 / 2$ & sil & $\mathrm{NCM}$ \\
\hline 1 & $\mathbf{R}$ & 1. & 2 & $18-32$ & 10YR $6 / 3$ & sil & NCM \\
\hline 1. & $\mathbf{R}$ & 2 & 1 & $0-18$ & 10YR $4 / 2$ & sil & NCM \\
\hline $1:$ & $\vec{k}$ & 2 & 2 & $18-33$ & $10 Y R 6 / 3$ & sil & $\mathrm{NCM}$ \\
\hline 1 & $\mathbf{R}$ & 3 & 1 & $0-16$ & 10YR $3 / 2$ & sil & NCM \\
\hline 1 & $\mathbf{R}$ & 3 & 1 & $16-32$ & 10YR $5 / 3$ & sil & NCM \\
\hline 1 & $\mathbf{R}$ & 4 & 1 & $0-20$ & 10YR $3 / 3$ & sil & NCM \\
\hline 1 & $\mathbf{R}$ & 4 & 2 & $20-37$ & 10YR 4/4 & sil & NCM. \\
\hline 1 & $S$ & 1 & 1 & $0-30$ & 10YR $3 / 2$ & si & NCM \\
\hline 1 & $S$ & 1 & 2 & $30-40$ & $10 Y R 5 / 2$ & si & NCM \\
\hline 1 & $S$ & 2 & 1 & $0-30$ & $10 Y R 4 / 2$ & sil & NCM \\
\hline 1 & $S$ & 2 & 2 & $30-40$ & $10 Y R 6 / 3$ & si & NCM \\
\hline 2 & A & 7 & 1 & $0-20$ & 10YR $6 / 1$ & sil & $\mathrm{NCM}$ \\
\hline 2 & $\mathbf{A}$ & 7 & 2 & $20-34$ & $10 Y R 4 / 2$ & sil & NCM \\
\hline 2 & A & 9 & 1 & $0-16$ & $10 \mathrm{YR} 4 / 2$ & sil & NCM \\
\hline 2 & A & 9 & 2 & $16-34$ & $10 \mathrm{YR} 6 / 3$ & sil & $\mathrm{NCM}$ \\
\hline 2 & A & 10 & 1 & $0-10$ & $10 \mathrm{YR} 5 / 3$ & sil & $\mathrm{NCM}$ \\
\hline 2 & A & 10 & 2 & $10-36$ & $10 \mathrm{YR} 5 / 6$ & si & $\mathrm{NCM}$ \\
\hline 2 & B & 7 & 1 & $0-26$ & $10 \mathrm{YR} 4 / 2$ & sil & $\mathrm{NCM}$ \\
\hline 2 & B & 7 & 2 & $26-35$ & $10 Y R 5 / 3$ & sil & $\mathrm{NCM}$ \\
\hline 2 & B & 8 & 1 & $0-30$ & 10YR $3 / 1$ & c & NCM \\
\hline 2 & B & 9 & 1 & $0-35$ & $10 Y R \quad 4 / 2$ & sil & $\mathrm{NCM}$ \\
\hline 2 & B & 10 & 1 & $0-16$ & 10YR 4/4 & sil & $\mathrm{NCM}$ \\
\hline 2 & B & 10 & 2 & $16-40$ & 10YR $5 / 4$ & si & $\mathrm{NCM}$ \\
\hline 2 & C & 6 & 1 & $0-32$ & $10 \mathrm{YR} 4 / 1$ & sicl & $N C M$ \\
\hline 2 & $C$ & 7 & 1 & 0.17 & 10YR 4/1 & sil & NCM \\
\hline 2 & C & 7 & 2 & $17-38$ & 10YR $7 / 4$ & sil & : NCM \\
\hline 2 & C & 8 & 1 & $0-15$ & 10YR $5 / 2$ & sil & NCM \\
\hline 2 & $\mathrm{C}$ & 8 & 2 & $15-36$ & 10YR 4/1 & sil & $\mathrm{NCM}$ \\
\hline 2 & $\mathrm{C}$ & 9 & 1 & $0-12$ & $10 Y R 6 / 2$ & sil & NCM \\
\hline 2 & $\mathrm{C}$ & 9 & 2 & $12-28$ & $10 Y R 4 / 2$ & sil & NCM \\
\hline 2 & $\mathrm{C}$ & 9 & 3 & $28-35$ & $10 Y R 5 / 2$ & si & NCM \\
\hline 2 & $\mathrm{C}$ & 10 & 1 & $0-10$ & 10YR $4 / 2$ & sil & NCM \\
\hline 2 & $\mathrm{C}$ & 10 & 2 & $10-35$ & 10YR $7 / 4$ & si & NCM \\
\hline 2 & $D$ & 6 & 1 & $0-35$ & $10 Y R \quad 4 / 2$ & sil & $\mathrm{NCM}$ \\
\hline 2 & D & 7 & 1 & $0-40$ & $10 Y R 4 / 2$ & sil & NCM \\
\hline 2 & D & 8 & 1 & $0-12$ & $10 \mathrm{YR} 4 / 3$ & sil & NCM \\
\hline 2 & $\mathrm{D}$ & 8 & 2 & $12-35$ & $10 Y R 5 / 3$ & si & NCM \\
\hline 2 & $\mathrm{D}$ & 9 & 1 & $0-30$ & $10 \mathrm{YR} 4 / 3$ & sil & $\mathrm{NCM}$ \\
\hline 2 & D & 9 & 1 & $30-40$ & $10 \mathrm{YR} 5 / 3$ & si & $\mathrm{NCM}$ \\
\hline 2 & $\mathrm{D}$ & 10 & 1 & $0-35$ & $10 Y R 5 / 3$ & sil & $\mathrm{NCM}$ \\
\hline 3 & A & 1 & 1 & $0-30$ & $10 \mathrm{YR} 5 / 3$ & si & NCM \\
\hline
\end{tabular}




\begin{tabular}{|c|c|c|c|c|c|c|c|}
\hline $\begin{array}{c}\text { SURVEY } \\
\text { AREA }\end{array}$ & TRANSECT & $\begin{array}{l}\text { SHOVEL } \\
\text { TEST NO. }\end{array}$ & $\begin{array}{l}\text { STRATUM/ } \\
\text { LEVEL }\end{array}$ & $\begin{array}{c}\text { DEPTH } \\
(\mathrm{cm})\end{array}$ & $\begin{array}{c}\text { SOIL } \\
\text { COLOR }\end{array}$ & $\begin{array}{c}\text { SOIL } \\
\text { TEXTURE }\end{array}$ & INCLUSIONS \\
\hline 3 & $\bar{A}$ & 2 & 1 & $0-15$ & $10 Y R 4 / 3$ & si & $\overline{N C M}$ \\
\hline 3 & A & 2 & 2 & $15-30$ & $10 Y R 3 / 2$ & sil & $\mathrm{NCM}$ \\
\hline 3 & A & 3 & 1 & $0-30$ & $10 Y R 5 / 2$ & si & $\mathrm{NCM}$ \\
\hline 3 & A & 4 & 1 & $0-30$ & $10 Y R 5 / 2$ & si & NCM \\
\hline 3 & A & 5 & 1 & $0-30$ & 10YR 3/1 & cl & NCM \\
\hline 3 & B & 1 & 1 & $0-33$ & $10 \mathrm{YR} 4 / 2$ & sil & $\mathrm{NCM}$ \\
\hline 3 & B & 2 & 1 & $0-18$ & $10 \mathrm{YR} 4 / 2$ & sil & NCM \\
\hline 3 & B & 2 & 2 & $18-36$ & $10 Y R \quad 4 / 3$ & sil & NCM \\
\hline 3 & B & 3 & 1 & $0-30$ & $10 \mathrm{YR} 5 / 2$ & sicl & $\mathrm{NCM}$ \\
\hline 3 & B & 4 & 1 & $0-13$ & $10 \mathrm{YR} 5 / 2$ & sicl & $\mathrm{NCM}$ \\
\hline 3 & B & 4 & 2 & $13-30$ & $10 \mathrm{YR} 6 / 2$ & sil & $\mathrm{NCM}$ \\
\hline 3 & B & 5 & 1 & $0-24$ & $10 \mathrm{YR} 6 / 2$ & sil & NCM \\
\hline 3 & B & 5 & 2 & $24-34$ & $10 \mathrm{YR} 5 / 2$ & mottled sil & NCM \\
\hline 3 & $\Rightarrow$ & 5 & 1 & $0-33$ & 10YR $2 / 2$ & sicl & $\mathrm{NCM}$ \\
\hline 3 & D & 5 & 1 & $0-30$ & $10 Y R 3 / 2$ & c & NCM \\
\hline 3 & $E$ & 1 & 1 & $0-12$ & $10 \mathrm{YR} 5 / 3$ & sil & NCM \\
\hline 3 & $\mathrm{E}$ & 1 & 2 & $12-28$ & 10 YR $4 / 3$ & sil & $\mathrm{NCM}$ \\
\hline 3 & $\mathrm{E}$ & 1 & 3 & 28-34 & $10 Y R \quad 4 / 2$ & sicl & $\mathrm{NCM}$ \\
\hline 3 & $E$ & 2 & 1 & $0-28$ & $10 \mathrm{YR} 3 / 2$ & sil & $\mathrm{NCM}$ \\
\hline 3 & $\mathrm{E}$ & 2 & 2 & $28-35$ & 10YR 5/3 & sil & $\mathrm{NCM}$ \\
\hline 3 & $\mathrm{E}$ & 3 & 1 & $0-12$ & $10 Y R$ S/2 & sil & $\mathrm{NCM}$ \\
\hline 3 & $\mathrm{E}$ & 3 & 2 & $12-28$ & 10 YR $5 / 3$ & sil & $\mathrm{NCM}$ \\
\hline 3 & $\mathrm{E}$ & 3 & 3 & $28-32$ & 10YR $6 / 3$ & sil & $\mathrm{NCM}$ \\
\hline 3 & $\mathbf{E}$ & 4 & 1 & $0-23$ & $10 \mathrm{YR} 4 / 2$ & sil & $\mathrm{NCM}$ \\
\hline 3 & E & 4 & 2 & $23-40$ & 10YR $7 / 3$ & sil & $\mathrm{NCM}$ \\
\hline 3 & $E$ & 5 & 1 & $0-33$ & $10 \mathrm{YR} 4 / 2$ & sil & $\mathrm{NCM}$ \\
\hline 3 & $\mathrm{E}$ & 6 & 1 & $0-22$ & 10 YR $5 / 2$ & sil & NCM \\
\hline 3 & $\mathbf{E}$ & 6 & 2 & $22-32$ & $10 Y R \quad 4 / 2$ & sil & $\mathrm{NCM}$ \\
\hline 3 & E & 7 & 1 & $0-32$ & $10 Y R \quad 4 / 1$ & sicl & $\mathrm{NCM}$ \\
\hline 3 & $\mathrm{~F}$ & 1 & 1 & $0-40$ & $10 \mathrm{YR} 4 / 2$ & sil & $\mathrm{NCM}$ \\
\hline 3 & $\mathbf{F}$ & 2 & 1 & 0.35 & $10 Y R \quad 4 / 2$ & sil & $\mathrm{NCM}$ \\
\hline 3 & $F$ & 3 & 1 & $0-35$ & $10 \mathrm{YR} 3 / 3$ & sicl & NCM \\
\hline 3 & F & 4 & 1 & $0-15$ & $10 \mathrm{YR} 4 / 2$ & sil & $\mathrm{NCM}$ \\
\hline 3 & F & 4 & 2 & $15-30$ & 10 YR $5 / 2$ & sil & $\mathrm{NCM}$ \\
\hline 3 & $F$ & 5 & 1 & $0-30$ & $10 \mathrm{YR} 4 / 2$ & sil & NCM \\
\hline 4 & $\mathrm{E}$ & 8 & 1 & $0-15$ & $10 \mathrm{YR} 4 / 2$ & sil & $\mathrm{NCM}$ \\
\hline 4 & $\mathrm{E}$ & 8 & 2 & $15-31$ & $10 Y R \quad 4 / 4$ & sil & NCM \\
\hline 4 & $E$ & 9 & 1 & $0-8$ & $10 Y R 5 / 3$ & mixed fills & $\mathrm{NCM}$ \\
\hline 4 & E & 9 & 2 & $8 \cdot 30$ & $10 \mathrm{YR} 3 / 1$ & 1 & NCM \\
\hline 4 & $\mathrm{E}$ & 9 & 3 & $30-38$ & $10 Y R 5 / 2$ & si & $\mathrm{NCM}$ \\
\hline 4 & F & 9 & 1 & $0=22$ & 10YR $3 / 2$ & sicl & $\mathrm{NCM}$ \\
\hline 4 & $F$ & 9 & 2 & $22-32$ & $10 Y R \quad 4 / 2$ & si & NCM \\
\hline 5 & A & 1 & 1 & $0-30$ & $10 \mathrm{YR} 6 / 3$ & cl & NCM \\
\hline 5 & A & 2 & 1 & $0-30$ & 10YR $6 / 3$ & cl & $\mathrm{NCM}$ \\
\hline 5 & A & 3 & 1 & $0-30$ & $10 Y R 5 / 3$ & cl & $\mathrm{NCM}$ \\
\hline 5 & A & 4 & 1 & $0-30$ & 10 YR $5 / 3$ & cl & $\mathrm{NCM}$ \\
\hline 5 & A & 5 & 1 & $0-30$ & $10 Y R 5 / 3$ & $\mathrm{cl}$ & $\mathrm{NCM}$ \\
\hline 5 & A & 6 & 1 & $0-25$ & $10 \mathrm{YR} 5 / 3$ & cl & $\mathrm{NCM}$ \\
\hline 5 & A & 7 & 2 & $25-40$ & $10 Y R 5 / 6$ & $\mathrm{cl}$ & NCM \\
\hline 5 & A & 8 & 1 & $0-30$ & $10 \mathrm{YR} 5 / 2$ & cl & $\mathrm{NCM}$ \\
\hline 5 & A & 9 & 1 & 0.30 & $10 \mathrm{YR} 5 / 2$ & cl & NCM \\
\hline 5 & A & 10 & 1 & $0-35$ & 10YR 5/2 & $\mathrm{cl}$ & $\mathrm{NCM}$ \\
\hline
\end{tabular}




\begin{tabular}{|c|c|c|c|c|c|c|c|}
\hline $\begin{array}{c}\text { SURVEY } \\
\text { AREA }\end{array}$ & TRANSECT & $\begin{array}{c}\text { SHOVEL } \\
\text { TEST NO. }\end{array}$ & $\begin{array}{l}\text { STRATUM/ } \\
\text { LEVEL }\end{array}$ & $\begin{array}{c}\text { DEPTH } \\
(\mathrm{cm})\end{array}$ & $\begin{array}{c}\text { SOIL } \\
\text { COLOR }\end{array}$ & $\begin{array}{c}\text { SOIL } \\
\text { TEXTURE }\end{array}$ & INCLUSIONS \\
\hline 5 & $\bar{A}$ & 11 & 1 & $0-35$ & $10 \mathrm{YR} 5 / 4$ & $\mathrm{cl}$ & $\mathrm{NCM}$ \\
\hline 5 & A & 12 & 1 & $0-35$ & 10YR $5 / 2$ & $\mathrm{cl}$ & $\mathrm{NCM}$ \\
\hline 5 & A & 13 & 1 & $0-30$ & $10 Y R 5 / 3$ & $\mathrm{cl}$ & $\mathrm{NCM}$ \\
\hline 5 & A & 14 & 1 & $0-30$ & 10YR $5 / 3$ & $\mathrm{cl}$ & $\mathrm{NCM}$ \\
\hline 5 & A. & 15 & 1 & $0-35$ & 10YR $3 / 2$ & $\mathrm{cl}$ & NCM \\
\hline 5 & A & 17 & 1 & $0-6$ & 10YR $4 / 3$ & sil & $\mathbf{N C M}$ \\
\hline 5 & A & 17 & 2 & $6-27$ & 10YR $4 / 2$ & sicl & NCM \\
\hline 5 & A & 17. & 3 & $27-40$ & 10YR $4 / 2$ & $c$ & $\mathrm{NCM}$ \\
\hline 5 & A & 18 & 1 & $0-6$ & $10 Y R 5 / 2$ & sil & NCM \\
\hline 5 & A & 18 & 2 & $6-26$ & 10YR $4 / 2$ & sic & $\mathrm{NCM}$ \\
\hline 5 & A & 18 & 3 & $26-38$ & $10 \mathrm{YR} 4 / 2$ & sic & NCM \\
\hline 5 & A & 19 & 1 & $0-5$ & 10YR $5 / 2$ & sil & NCM \\
\hline 5 & A & 19 & 2 & $5-28$ & $10 \mathrm{YR} 4 / 2$ & sil & $\mathrm{NCM}$ \\
\hline 5 & A & 19 & 3 & $28-35$ & $10 Y R 4 / 1$ & sic & $\mathrm{NCM}$ \\
\hline 5 & A & 20 & 1 & $0-7$ & 10YR $5 / 2$ & sil & NCM \\
\hline 5 & A & 20 & 2 & $7-25$ & $2.5 Y 5 / 2$ & sicl & NCM \\
\hline 5 & A & 20 & 3 & $25-39$ & $10 Y R 4 / 2$ & sicl & $\mathrm{NCM}$ \\
\hline 5 & A & 21 & 1 & $0-13$ & 10YR $5 / 2$ & sicl & NCM \\
\hline 5 & A & 21 & 2 & $13-33$ & $10 Y R 4 / 2$ & sicl & NCM \\
\hline 5 & A & 22 & 1 & $0-7$ & $10 Y R 5 / 2$ & sil & NCM \\
\hline 5 & A & 22 & 2 & $7-27$ & 10YR $4 / 2$ & sicl & NCM \\
\hline 5 & A & 22 & 3 & $27-39$ & 10YR $5 / 3$ & sic & $\mathrm{NCM}$ \\
\hline 5 & B & 1 & 1 & $0-32$ & $10 Y R 5 / 3$ & si & $\mathrm{NCM}$ \\
\hline 5 & B & 2 & 1 & $0-32$ & 10YR $5 / 3$ & si & $\mathrm{NCM}$ \\
\hline 5 & B & 3 & 1 & $0-30$ & 10YR $5 / 2$ & sil & $\mathrm{NCM}$ \\
\hline 5 & B & 4 & 1 & $0-33$ & 10YR $5 / 4$ & sl & $\mathrm{NCM}$ \\
\hline 5 & $\mathbf{B}$ & 5 & 1 & $0-40$ & $10 Y R \quad 4 / 4$ & sl & $\mathrm{NCM}$ \\
\hline 5 & B & $5-\mathrm{N}$ & 1 & $0-36$ & 10YR $5 / 4$ & sl & 1 historic sherd \\
\hline 5 & B & $5-E$ & 1 & $0-33$ & 10YR $5 / 4$ & sil & NCM \\
\hline 5 & B & $5-S$ & 1 & $0-30$ & 10YR $5 / 3$ & si & $\mathrm{NCM}$ \\
\hline 5 & B & $5-W$ & 1 & $0-32$ & $10 Y R \quad 4 / 4$ & sil & NCM \\
\hline 5 & B & 6 & 1 & $0-30$ & 10YR $5 / 2$ & scl & NCM \\
\hline 5 & B & 7 & 1 & $0-30$ & $10 \mathrm{YR} 4 / 2$ & sil & NCM \\
\hline 5 & B & 8 & 1 & $0-32$ & 10YR $4 / 3$ & sil & $\mathrm{NCM}$ \\
\hline 5 & B & 9 & 1 & $0-31$ & $10 Y R 6 / 4$ & sil & $\mathrm{NCM}$ \\
\hline 5 & B & 10 & 1 & $0-31$ & 10YR $6 / 4$ & sil & $\mathrm{NCM}$ \\
\hline 5 & B & 11 & 1 & $0-34$ & 10YR $3 / 2$ & $\mathrm{cl}$ & $\mathrm{NCM}$ \\
\hline 5 & B & 12 & 1 & $0-32$ & 10YR $4 / 3$ & $\mathrm{cl}$ & NCM \\
\hline 5 & B & 13 & 1. & $0-30$ & 10YR $3 / 2$ & cl & NCM \\
\hline 5 & B & 14 & 1 & 0.45 & IOYR $4 / 2$ & $\mathrm{cl}$ & NCM \\
\hline 5 & B & 15 & 1 & $0-30$ & $10 Y R 3 / 2$ & sil & NCM \\
\hline 5 & B & 17 & 1 & $0-5$ & $10 Y R 5 / 2$ & sil & NCM \\
\hline 5 & B & 17 & 2 & $5-22$ & IOYR $4 / 2$ & sic & $\mathrm{NCM}$ \\
\hline 5 & B & 17 & 3 & $22-36$ & $10 Y R 5 / 3$ & mottled sic & $\mathrm{NCM}$ \\
\hline 5 & B & 18 & 1 & $0-8$ & 10YR $5 / 2$ & sil & NCM \\
\hline 5 & B & 18 & 2 & $8 \cdot 35$ & $10 \mathrm{YR} 5 / 2$ & sic & NCM \\
\hline 5 & B & 19 & 1 & 0.6 & $10 Y R 4 / 1$ & sil & $\mathrm{NCM}$ \\
\hline 5 & B & 19 & 2 & $6 \cdot 32$ & 10YR $3 / 3$ & sil & $\mathrm{NCM}$ \\
\hline 5 & B & 19 & 3 & $32-35$ & $10 Y R 5 / 3$ & sic & NCM \\
\hline 5 & B & 20 & 1 & $0-7$ & 10YR $5 / 2$ & sil & NCM \\
\hline 5 & B & 20 & 2 & $7-35$ & 10YR $3 / 2$ & sicl & $\mathrm{NCM}$ \\
\hline 5 & $\mathrm{~B}$ & 21 & 1 & $0-26$ & $10 Y R 6 / 2$ & mottled sil & NCM \\
\hline
\end{tabular}




\begin{tabular}{|c|c|c|c|c|c|c|c|}
\hline $\begin{array}{c}\text { SURVEY } \\
\text { AREA }\end{array}$ & TRANSECT & $\begin{array}{l}\text { SHOVEL } \\
\text { TEST NO. }\end{array}$ & $\begin{array}{l}\text { STRATUM/ } \\
\text { LEVEL }\end{array}$ & $\begin{array}{c}\text { DEPTH } \\
(\mathrm{cm}) \\
\end{array}$ & $\begin{array}{c}\text { SOIL } \\
\text { COLOR }\end{array}$ & $\begin{array}{c}\text { SOIL } \\
\text { TEXTURE }\end{array}$ & INCLUSIONS \\
\hline 5 & $\bar{B}$ & 21 & 2 & $26-37$ & $10 \mathrm{YR} 4 / 2$ & si & NCM \\
\hline 5 & B & 22 & 1 & $0-10$ & $10 Y R 5 / 2$ & sil & NCM \\
\hline 5 & B & 22 & 2 & $10-28$ & 10YR $4 / 2$ & sil & $\mathrm{NCM}$ \\
\hline 5 & B & 22 & 3 & $28-39$ & 10YR 5/4 & sic & $\mathrm{NCM}$ \\
\hline 5 & B & 23 & 1 & $0-8$ & $10 Y R 5 / 2$ & sil & $\mathrm{NCM}$ \\
\hline 5 & B & 23 & 2 & $8-35$ & $10 \mathrm{YR} 4 / 1$ & sic & 1 bottle glass sherd \\
\hline 5 & Random & 1 & 1 & $0-10$ & 10YR $6 / 2$ & sil & NCM \\
\hline 5 & Random & 1 & 2 & $10-42$ & $10 Y R 4 / 2$ & sil & $\mathrm{NCM}$ \\
\hline 5 & Random & 1 & 3 & $42-46$ & $10 Y R 5 / 4$ & sil & NCM \\
\hline 5 & Random & 2 & 1 & $0-7$ & $10 Y R 5 / 2$ & sil & NCM \\
\hline 5 & Random & 2 & 2 & $7-37$ & $10 \mathrm{YR} 4 / 2$ & sil & $\mathrm{NCM}$ \\
\hline 5 & Random & 2 & 3 & $37-43$ & 10YR $5 / 3$ & sic & $\mathrm{NCM}$ \\
\hline 5 & Random & 3 & 1 & $0-7$ & $10 Y R 5 / 2$ & sil & NCM \\
\hline 5 & Random & 3 & 2 & $7-39$ & $10 Y R 4 / 2$ & sil & $\mathrm{NCM}$ \\
\hline 5 & Random & 3 & 3 & $39-44$ & $10 Y R 4 / 3$ & sil & $\mathrm{NCM}$ \\
\hline 5 & Random & 4 & 1 & $0-6$ & IOYR $6 / 2$ & sil & $\mathrm{NCM}$ \\
\hline 5 & Random & 4 & 2 & $6-39$ & $10 \mathrm{YR} 4 / 2$ & sil & $\mathrm{NCM}$ \\
\hline \multicolumn{5}{|c|}{ MUNSELL COLOR NOTATIONS } & \multicolumn{3}{|c|}{ SOL TEXTURE ABBREVIATIONS } \\
\hline $2.5 Y 5 / 2$ & \multicolumn{4}{|l|}{ grayish brown } & $\varepsilon$ & \multicolumn{2}{|l|}{ sand } \\
\hline 10YR $2 / 1$ & \multicolumn{4}{|l|}{ black } & is & \multicolumn{2}{|l|}{ loamy sand } \\
\hline $10 Y R 2 / 2$ & \multicolumn{4}{|l|}{ very dark brown } & sl & \multicolumn{2}{|l|}{ sandy loam } \\
\hline 10YR 3/1 & \multicolumn{4}{|c|}{ very dark gray } & 1 & \multicolumn{2}{|l|}{ loam } \\
\hline 10YR $3 / 2$ & \multicolumn{4}{|c|}{ very dark grayish brown } & sil & \multicolumn{2}{|l|}{ silt loam } \\
\hline $10 Y R 3 / 3$ & \multicolumn{4}{|c|}{ dark brown } & sicl & \multicolumn{2}{|l|}{ silty clay loam } \\
\hline 10YR $4 / 1$ & \multicolumn{4}{|l|}{ dark gray } & $\mathrm{cl}$ & \multicolumn{2}{|l|}{ clay loam } \\
\hline $10 \mathrm{YR} 4 / 2$ & \multicolumn{4}{|c|}{ dark grayish brown } & $\varepsilon \mathrm{cl}$ & \multicolumn{2}{|l|}{ sandy clay luadn } \\
\hline $10 Y R 4 / 3$ & \multicolumn{4}{|c|}{ dark brown/brown } & sic & \multicolumn{2}{|l|}{ silty clay } \\
\hline $10 \mathrm{YR} 4 / 4$ & \multicolumn{4}{|c|}{ dark yellowish brown } & c & \multicolumn{2}{|l|}{ clay } \\
\hline 10YR 5/1 & \multicolumn{7}{|c|}{ gray } \\
\hline $10 Y R 5 / 2$ & \multicolumn{7}{|l|}{ grayish brơwII } \\
\hline 10YR $5 / 3$ & brown & & & & NCM & No Cultural $\mathrm{Ma}$ & erial \\
\hline 10YR $5 / 4$ & yellowish brou & & & & & & \\
\hline 10YR $5 / 6$ & yellowish brov & & & & & & \\
\hline 10YR $6 / 1$ & gray/light gray & & & & & & \\
\hline 10YR $6 / 2$ & light brownish & gray & & & & & \\
\hline $10 Y R 6 / 3$ & pale brown & & & & & & \\
\hline 10YR 6/4 & light yellowish & h brown & & & & & \\
\hline 10YR $6 / 6$ & brownish yello & & & & & & \\
\hline 10YR $7 / 2$ & light gray & & & & & & \\
\hline IUYK $7 / 3$ & very pale brow & & & & & & \\
\hline 10YR $7 / 4$ & very palc brów & & & & & & \\
\hline 10YR $8 / 2$ & white & & & & & & \\
\hline
\end{tabular}


APPENDIX B

SITE SURVEY FORMS

B-1 
Site ivame Texoma Pipeline Tract 211

Other Site Designations

Instructions for Reaching Site from Sulphur, proceed south on Rt. 27 to Rt. 1133; turn left (east) and go ca. 800 feet; site is in pasture south of 1133, about

500 feet south of road Parish Calcasieu

USGS Quad: (name, date series) West Lake, 1955 (rev. 1975), 7.5-minute NE $1 / 4$ of the NW $1 / 4$ of the NW $1 / 4$ of Section 2 Township $11 \mathrm{~S}$ Range $10 \mathrm{~W}$

UTM Coordinates: Zone 15 Easting 464,860 Geographical Coordinates: Latitude $30^{\circ} 8^{\prime} 18^{\prime \prime} \quad$ Longitude $93^{\circ} 22^{\prime} 5^{\prime \prime}$

PHYSICAL SETTING

Land Form Pleistocene Prairie Terrace Geologic Processes

Elevation $10 \mathrm{ft}$. ms 1

Slope $\quad 0-2 \%$ Site Position with Respect to Terrain site occupies a nearly level field

Nearest Water 2,000 feet to unnamed bayou Flooding_ none

Soil Characteristics silt loam

Floral Communities pasture grass, one shade tree

Faunal Communities

Other Potential Resources

Nearest known Site 16 CU 175

\section{SITE DESCRIPTION}

Site Size $300 \mathrm{ft}(90 \mathrm{~m}) \times 125 \mathrm{ft}(38 \mathrm{~m})$ Plan

Orientation site extends out of $\mathrm{R}-\mathrm{O}-\mathrm{W}$ Stratigraphy artifacts recovered from A-horizon

Artifact Density low

Artifact Distribution cencentrated cleser

to tree Cultural Features none

Cultural Affiliation historic--twentieth century

Presumed Function residential

\section{COLLECTIONS}

Survey Method shovel testing along transects parallel to pipeline right-of-way Assessment of Collecting Conditions poor

Description of Material whiteware/ironstone, clear glass (continuous thread closure), brick, UID nails (prob. wire), scissors, yellowware, stoneware (both Albany glazed \& Bristol glazed)

\section{CONDITIONS}

Present Use pasture Erosion or Disturbance none apparent

Probable Future Destruction destruction froa construction of pipeline 
Research Potential minimal

State or National Register Eligibility ineligible

Recommendations no Eurther work

\section{QUAD MAP OF SITE AREA}

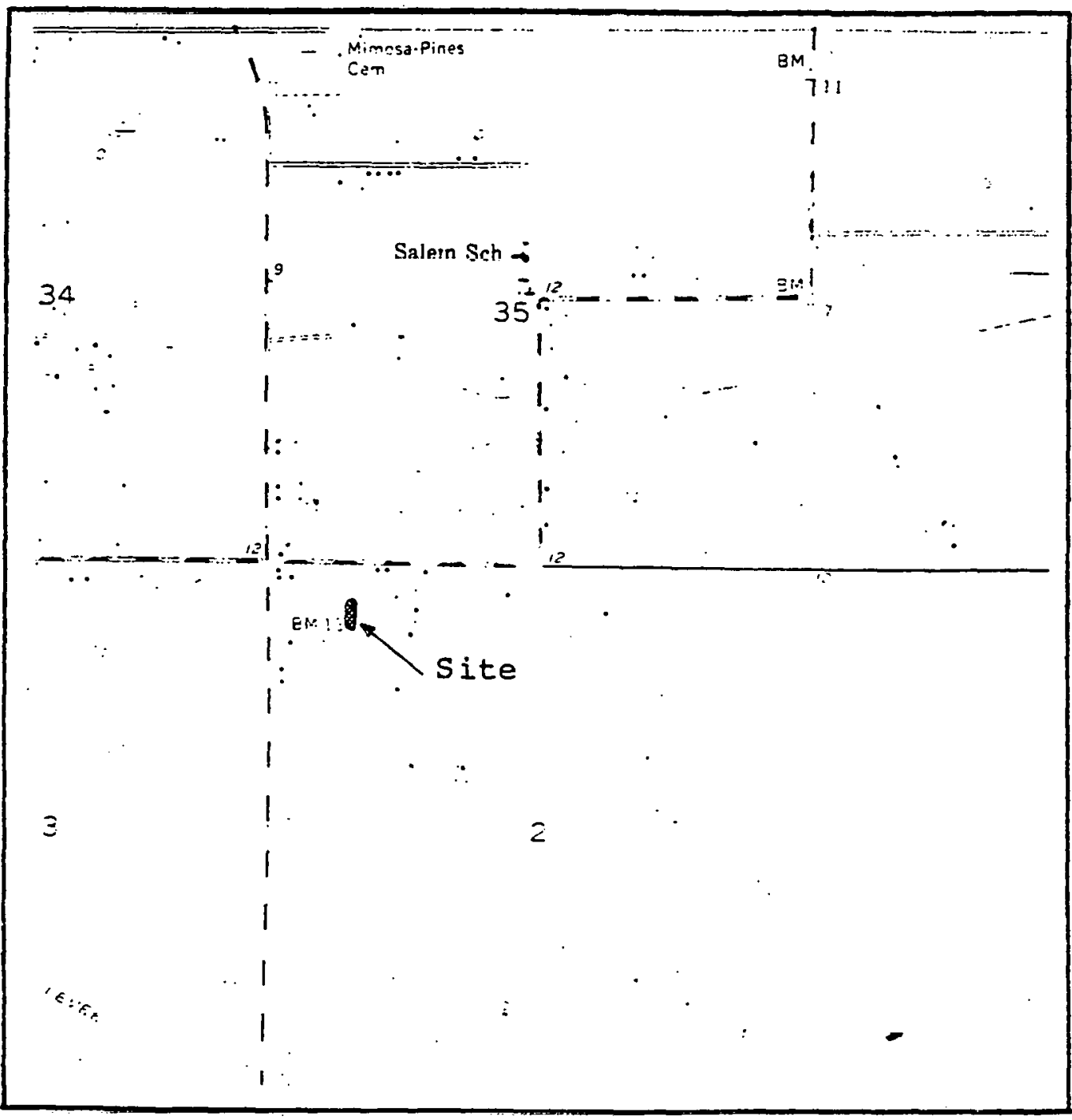

Owner and Address H. R. Norwood, Rt. 3, Box 1249; Sulphur, LA 70663

- Tenant and Address

Informants none

- Previous Investigations

none

Previous Collections and Availability

\section{References}

Photographs and Maps

Remarks to be discussed in survey report on TExOMA pipeline 
THIS PAGE

\section{WAS INTENTIONALLY LEFT BLANK}




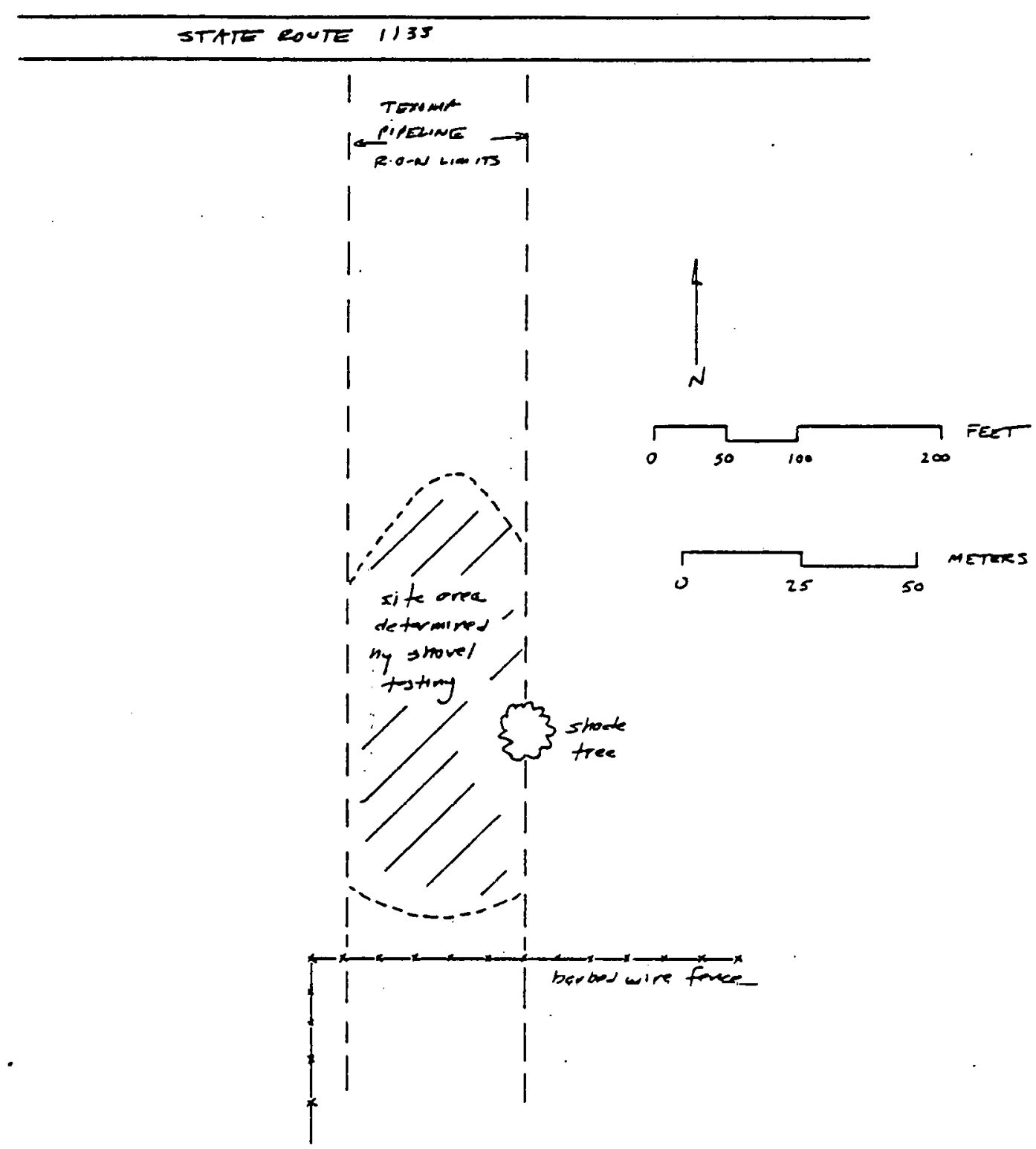

Scale as shown

Drawn by C. LeeDecker

Date August 1987 
Site Name Texoma Pipeline Tract 101 State Survey No.

Other Site Designations

Instructions for Reaching Site from Sulphur, go south of Rt. 27 to Hackberry; follow signs to Strategic Petroleum Reserve No. 3 (SPR3); site is about 400 feet east of

SPR3, along Texoma Pipeline right-of-way Parish Cameron

USGS Quad: (name, date series) Browns Lake, 1982, 7.5-minute

SW 1/4 of the NW 1/4 of the NNJ 1/4 of Section_21 Township $12 \mathrm{~S}$ Range $10 \mathrm{~V}$

UTM Coordinates: Zone 15 Easting 461,470_Northing 3,318,400

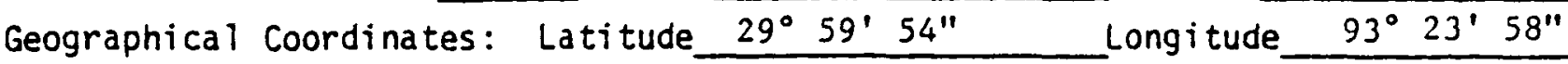

PHYSICAL SETTING

Land Formpimple mound on apron of salt dome Geologic Processes

Elevation ca. $15 \mathrm{ft}$. ms I

Slope $0-5 \% \quad$ Site Position with Respect to Terrain top uf pimple mound

Nearest Water Black Lake Bayou, 2,700 feet_Flooding

Soil Characteristics fine sandy loam

Floral Communities deciduous forest

Faunal Communities

Other Potential Resources nearby marsh area

Nearest known Site 16 C:I 90 (Ellender Home)

SITE DESCRIPTION

Site Size (isolated find spot) Plan

Orientation Stratigraphy artifact recovered from

A-horizon, fine sandy loam

Artifact Density low

Artifact Distribution

Cultural Features none

Cultural Affiliation hiscoric

Presumed Function isolated find

- COLLECTIONS

Survey Method shovel testing along transects parallel to right-of-way

Assessment of Collecting Conditions poor

Description of Material hard redware with white slio overlain by a clear glaze, exfoliated (poss. tile sherd)

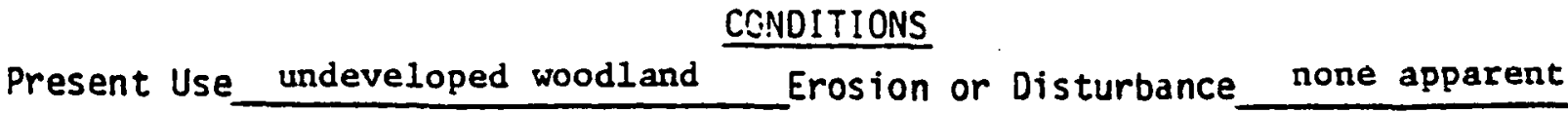

Probable Future Destruction destruction from construction of pipeline 
State or National Register Eligibility ineligible Recommendations no further work

\section{QUAD MAP OF SITE AREA}

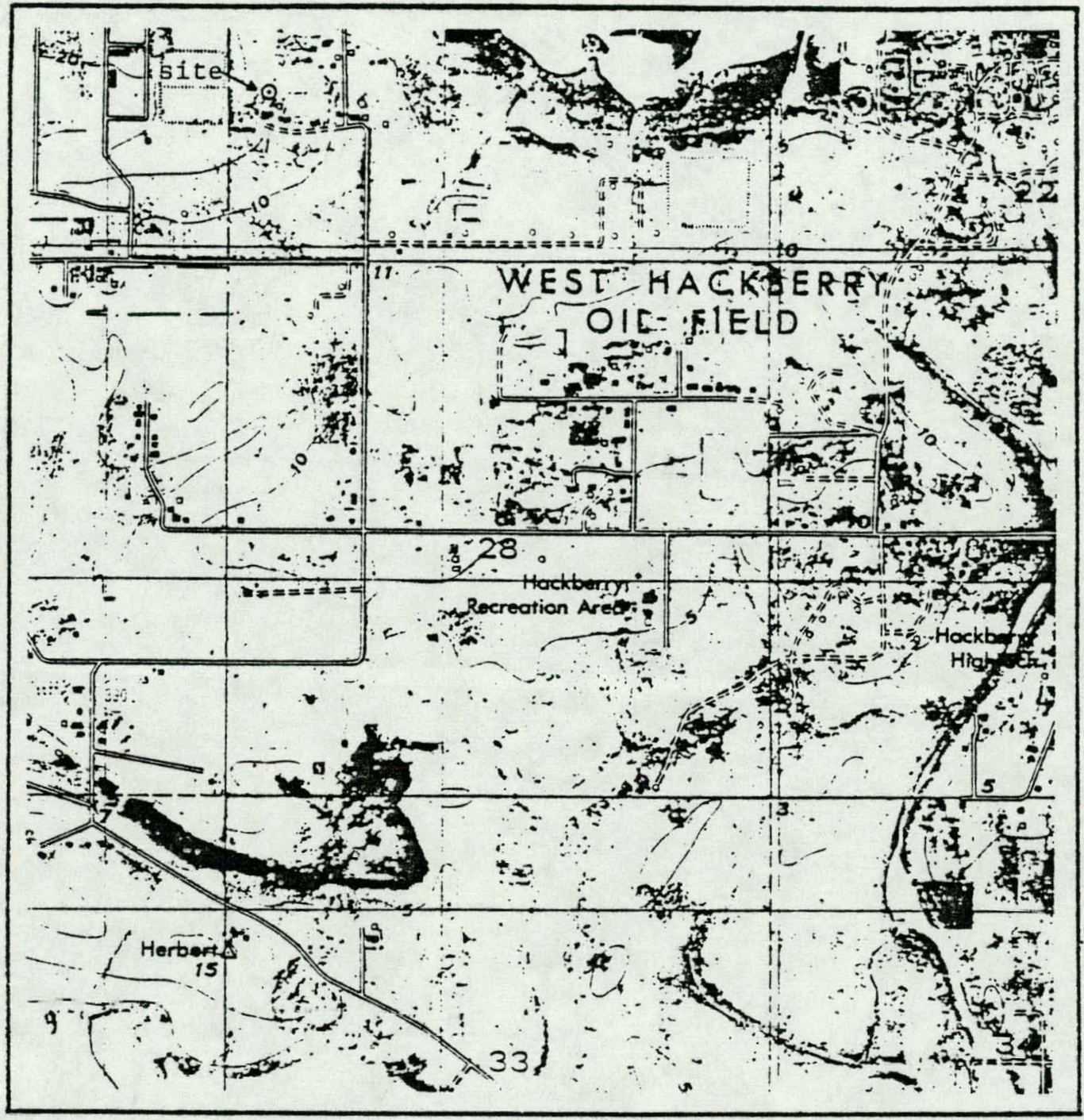

scale:

1: 24,000

\section{RECORDS}

Owner and Address AMOCO Production Co., 2800 Veterams Memorial Blvd., Metarie, LA 70002

Tenant and Address

Informants none

Previous Investigations

none

Previous Collections and Availability

\section{References}

\section{Photographs and Maps}

Remarks to be discussed in survey report of TExOMA pipeline 
APPENDIX C

SHOVEL TEST TABLE--SITE 16CU205

C-1 


\begin{tabular}{|c|c|c|c|c|c|}
\hline $\begin{array}{c}\text { COORDIN } \\
\text { NORTH }\end{array}$ & S: & $\begin{array}{c}\text { STRATUM/ } \\
\text { LEVEL }\end{array}$ & $\begin{array}{c}\text { DEPTH } \\
(\mathrm{cm})\end{array}$ & $\begin{array}{c}\text { SOIL } \\
\text { COLOR }\end{array}$ & $\begin{array}{c}\text { SOIL } \\
\text { TEXTURE }\end{array}$ \\
\hline 15 & 5 & 1 & $0-8$ & $10 \mathrm{YR} 5 / 3$ & sil \\
\hline 15 & 5 & 2 & $8 \cdot 42$ & 10YR $5 / 2$ & sil \\
\hline 25 & 5 & 1 & $0-17$ & $10 Y R \quad 6 / 3$ & sil \\
\hline 25 & 5 & 2 & $17-38$ & $10 \mathrm{YR} 4 / 3$ & sil \\
\hline 35 & 5 & 1 & $0-10$ & $10 Y R 5 / 3$ & sil \\
\hline 35 & 5 & 2 & $10-40$ & $10 Y R 4 / 3$ & sil \\
\hline 35 & 5 & 3 & $40-50$ & 10YR $6 / 4$ & sil \\
\hline 45 & 5 & 1 & $0-14$ & $10 \mathrm{YR} 4 / 4$ & sil \\
\hline 45 & 5 & 2 & $14-40$ & $10 \mathrm{YR} 4 / 2$ & sil \\
\hline 45 & 5 & 3 & $40-55$ & $10 \mathrm{YR} 6 / 2$ & sicl \\
\hline 55 & 5 & 1 & $0-10$ & $10 Y R 5 / 2$ & sil \\
\hline 55 & 5 & 2 & $10-46$ & $10 Y R \quad 4 / 2$ & sil \\
\hline 55 & 5 & 3 & $46-55$ & $10 \mathrm{YR} 6 / 2$ & sicl \\
\hline 65 & 5 & 1 & $0=9$ & $10 Y \mathrm{YK} 5 / 2$ & sil \\
\hline 65 & 5 & 2 & $9-43$ & $10 \mathrm{YR} 4 / 3$ & sil \\
\hline 65 & 5 & 3 & $43-48$ & $10 \mathrm{YR} 6 / 3$ & sicl \\
\hline 75 & 5 & 1 & $0-40$ & $10 Y R \quad 3 / 2$ & sil \\
\hline 75 & 5 & 2 & $40-50$ & $10 Y R 5 / 3$ & si \\
\hline 10 & 10 & 1 & $0-10$ & 10YR $5 / 3$ & sil \\
\hline 10 & 10 & 2 & $10-42$ & $10 \mathrm{YR} 4 / 2$ & mottled sil \\
\hline 20 & 10 & 1 & $0-9$ & 10YR $5 / 3$ & sil \\
\hline 20 & 10 & 2 & $9-40$ & $10 Y R 4 / 2$ & sicl \\
\hline 30 & 10 & 1 & $0-5$ & $10 Y R 5 / 3$ & sil \\
\hline 30 & 10 & 2 & $5-43$ & $10 Y R \quad 4 / 2$ & sil \\
\hline 40 & 10 & 1 & $0-6$ & 10YR $5 / 2$ & sil \\
\hline 40 & 10 & 2 & $6-42$ & $10 \mathrm{YR} 3 / 2$ & sil \\
\hline 40 & 10 & 3 & $42-47$ & $10 \mathrm{YR} 6 / 2$ & sil \\
\hline 50 & 10 & 1 & $0-7$ & $10 \mathrm{YR} 4 / 2$ & sil \\
\hline 50 & 10 & 2 & $7-44$ & 10 YR $4 / 2$ & sicl \\
\hline 60 & 10 & 1 & $0-6$ & 10YR $4 / 2$ & sicl \\
\hline 60 & 10 & 2 & $6-43$ & $10 \mathrm{YR} 3 / 2$ & motcled sicl \\
\hline 70 & 10 & 1 & $0-9$ & $10 Y R \quad 1 / 2$ & sil \\
\hline 70 & 10 & 2 & $9-42$ & $10 Y R 3 / 2$ & si \\
\hline 80 & 10 & 1 & 0.35 & IOYR $3 / 2$ & sil \\
\hline 80 & 10 & 2 & $35-40$ & 10 YR $5 / 3$ & si \\
\hline 90 & 10 & 1 & $0-40$ & $10 \mathrm{YR} 4 / 2$ & sil \\
\hline 100 & 10 & 1 & $0-7$ & $10 \mathrm{YR} 4 / 1$ & sil \\
\hline 100 & 10 & 2 & $7-30$ & 10YR 3/1 & c \\
\hline 110 & 10 & 1 & $0=8$ & IUYR 4/1 & sil \\
\hline 110 & 10 & 2 & $8-30$ & 10YR 3/1 & c \\
\hline 15 & 15 & 1 & 0.7 & 10YR 4/2 & sicl \\
\hline 15 & 15 & 2 & $7-32$ & $10 \mathrm{YR} 5 / 3$ & moutled sil \\
\hline 15 & 15 & 3 & $32-44$ & $2.5 Y 6 / 4$ & sil \\
\hline 25 & 15 & 1 & $0-6$ & $10 \mathrm{YR} 4 / 2$ & sicl \\
\hline 25 & 15 & 2 & $6-42$ & $10 \mathrm{YR} 3 / 2$ & sicl \\
\hline 35 & 15 & 1 & $0-6$ & $10 Y R 4 / 2$ & sil \\
\hline 35 & 15 & 2 & 6.42 & 10YR 3/1 & sicl \\
\hline 45 & 15 & 1 & 0.7 & 10YR 3/2 & sil \\
\hline 45 & 15 & 2 & $7-32$ & 10YR 4/2 & mottled sil \\
\hline 45 & 15 & 3 & $32-42$ & $10 Y R 5 / 3$ & mottled sicl \\
\hline 55 & 15 & 1 & 0.36 & 10YR 3/2 & sil \\
\hline 55 & 15 & 2 & $36-50$ & $10 Y R 5 / 3$ & si \\
\hline
\end{tabular}




\begin{tabular}{|c|c|c|c|c|c|}
\hline \multicolumn{2}{|c|}{ COORDINATES: } & \multirow{2}{*}{$\begin{array}{l}\text { STRATUM/ } \\
\text { LEVEL }\end{array}$} & \multirow{2}{*}{$\begin{array}{c}\text { DEPTH } \\
(\mathrm{cm})\end{array}$} & \multirow{2}{*}{$\begin{array}{c}\text { SOIL } \\
\text { COLOR }\end{array}$} & \multirow{2}{*}{$\begin{array}{c}\text { SOIL } \\
\text { TEXTURE }\end{array}$} \\
\hline NORTH & EAST & & & & \\
\hline 65 & 15 & 1 & $0-35$ & $10 Y R 3 / 2$ & sil \\
\hline 65 & 15 & 2 & $35-45$ & $10 \mathrm{YR} 5 / 3$ & si \\
\hline 75 & 15 & 1 & $0-45$ & $10 \mathrm{YR} 3 / 2$ & sil \\
\hline 75 & 15 & 2 & $45-50$ & 10YR $5 / 3$ & si \\
\hline 85 & 15 & 1 & $0-40$ & $10 \mathrm{YR} 3 / 2$ & sil \\
\hline 85 & 15 & 2 & $40-50$ & $10 \mathrm{YR} 4 / 3$ & si \\
\hline 95 & 15 & 1 & $0-40$ & 10YR 3/1 & c \\
\hline 105 & 15 & 1 & $0-11$ & $10 Y R 4 / 2$ & sil \\
\hline 105 & 15 & 2 & $11-40$ & 10YR 3/2 & sic \\
\hline 10 & 20 & 1 & $0-7$ & 10YR 4/2 & sil \\
\hline 10 & 20 & 2 & $7-32$ & 10YR 3/2 & sil \\
\hline 10 & 20 & 3 & $32-36$ & $10 Y R 5 / 3$ & sil \\
\hline 20 & 20 & 1 & $0-12$ & 10 YR $5 / 3$ & 1 \\
\hline 20 & 20 & 2 & $12-40$ & $10 Y R 5 / 2$ & mixed fills \\
\hline 30 & 20 & 1 & $0-15$ & 10YR 4/2 & sicl \\
\hline 30 & 20 & 2 & $15-44$ & 10YR 5/2 & sicl \\
\hline 40 & 20 & 1 & $0-48$ & $10 \mathrm{YR} 4 / 2$ & sil \\
\hline 40 & 20 & 2 & $48-55$ & 10YR 5/2 & si \\
\hline 50 & 20 & 1 & $0-40$ & 10YR 3/2 & sil \\
\hline 50 & 20 & 2 & $40-50$ & 10YR $6 / 2$ & si \\
\hline 60 & 20 & 1 & $0-45$ & 10YR 3/1 & sil \\
\hline 60 & 20 & 2 & $45-56$ & $10 \mathrm{YR} 5 / 3$ & si \\
\hline 70 & 20 & 1 & $0-50$ & 10YR $2 / 2$ & sil \\
\hline 80 & 20 & 1 & $0-40$ & 10YR $4 / 2$ & sil \\
\hline 90 & 20 & 1 & $0-7$ & $10 \mathrm{YR} 4 / 2$ & sil \\
\hline 90 & 20 & 2 & $7-40$ & 10YR 5/2 & sicl \\
\hline 100 & 20 & 1 & $0-8$ & 10YR 5/1 & sil \\
\hline 100 & 20 & 2 & $8-40$ & 10YR 3/1 & sil \\
\hline 110 & 20 & 1 & $0-13$ & $10 \mathrm{YR} 4 / 2$ & sil \\
\hline 110 & 20 & 2 & $13-30$ & 10YR $2 / 2$ & c \\
\hline 110 & 20 & 3 & $30-43$ & 10YR 5/1 & cl \\
\hline 5 & 25 & 1 & 0.10 & 10YR 5/2 & sil \\
\hline 5 & 25 & 2 & $10-45$ & 10YR $2 / 2$ & sic \\
\hline 15 & 25 & 1 & $0-35$ & 10YR $5 / 2$ & sil \\
\hline 25 & 25 & 1 & $0-13$ & 10YR $5 / 2$ & sil \\
\hline 25 & 25 & 2 & $13-44$ & 10YR 4/3 & sicl \\
\hline 35 & 25 & 1 & 0.12 & $10 Y \mathrm{R} 4 / 3$ & sil \\
\hline 35 & 25 & 2 & $12-37$ & 10YR 3/2 & sicl \\
\hline 45 & 25 & 1 & $0-34$ & 10YR 3/2 & sil \\
\hline 45 & 25 & 2 & $34-46$ & 10YR $5 / 3$ & sil \\
\hline 55 & 25 & 1 & $0-31$ & I0YR 4/2 & sil \\
\hline 55 & 25 & 2 & 3141 & 10 YR $6 / 3$ & sil \\
\hline 65 & 25 & 1 & $0-33$ & 10YR 3/1 & sil \\
\hline 65 & 25 & 2 & $33-38$ & 10YR 5/3 & sil \\
\hline 75 & 25 & 1 & $0-25$ & 10YR 3/2 & sil \\
\hline 75 & 25 & 2 & $25-38$ & IUYK 4/1 & $c$ \\
\hline 85 & 25 & 1 & $0-37$ & 10YR $3 / 2$ & sil \\
\hline 95 & 25 & 1 & $0-32$ & 10YR 4/1 & sicl \\
\hline 105 & 25 & 1 & $0-44$ & 10YR 4/2 & sicl \\
\hline 10 & 30 & 1 & $0-9$ & $10 Y R 5 / 3$ & sil \\
\hline 10 & 30 & 2 & $9-40$ & 10 YR 4/2 & sicl \\
\hline 20 & 30 & 1 & $0-38$ & 10YR $4 / 2$ & sil \\
\hline
\end{tabular}




\begin{tabular}{|c|c|c|c|c|c|}
\hline \multicolumn{2}{|c|}{ COORDINATES: } & \multirow{2}{*}{$\begin{array}{l}\text { STRATUM/ } \\
\text { LEVEL }\end{array}$} & \multirow{2}{*}{$\begin{array}{c}\text { DEPTH } \\
(\mathrm{cm})\end{array}$} & \multirow{2}{*}{$\begin{array}{l}\text { SOIL } \\
\text { COLOR }\end{array}$} & \multirow{2}{*}{$\begin{array}{c}\text { SOIL } \\
\text { TEXTURE }\end{array}$} \\
\hline NORTH & EAST & & & & \\
\hline 20 & 30 & 2 & $38-46$ & 10YR $6 / 3$ & sil \\
\hline 30 & 30 & 1 & $0-11$ & 10YR $5 / 3$ & sil \\
\hline 30 & 30 & 2 & $11-40$ & $10 Y R 3 / 3$ & sicl \\
\hline 40 & 30 & 1 & $0-40$ & $10 Y R 4 / 2$ & sil \\
\hline 50 & 30 & 1 & $0-18$ & $10 Y R 4 / 2$ & sil \\
\hline 50 & 30 & 2 & $18-42$ & 10YR 4/3 & sil \\
\hline 60 & 30 & 1 & $0-40$ & $10 Y R \quad 4 / 3$ & sil \\
\hline 70 & 30 & 1 & $0-35$ & 10YR 3/2 & sil \\
\hline 80 & 30 & 1 & $0-18$ & $10 Y R 3 / 2$ & sil \\
\hline 80 & 30 & 2 & $18-30$ & 10YR 4/1 & sic \\
\hline 90 & 30 & 1 & $0-28$ & 10YR $5 / 3$ & sil \\
\hline 90 & 30 & 2 & $28-40$ & 10YR $5 / 3$ & cl \\
\hline 100 & 30 & 1 & $0-13$ & 10YR $3 / 2$ & sil \\
\hline 100 & 30 & 2 & $13-30$ & 10 YR $3 / 1$ & si \\
\hline 105 & 30 & 1 & $0-10$ & $10 Y R 3 / 2$ & sil \\
\hline 105 & 30 & 2 & $10-30$ & 10YR $3 / 2$ & si \\
\hline 105 & 30 & 3 & $30-42$ & 10YR $5 / 3$ & cl \\
\hline 110 & 30 & 1 & $0-10$ & 10YR $3 / 2$ & sil \\
\hline 110 & 30 & 2 & $10-30$ & 10YR 3/2 & si \\
\hline 110 & 30 & 3 & $30-40$ & 10 YR $5 / 3$ & cl \\
\hline 5 & 35 & 1 & $0-6$ & 10YR $5 / 2$ & sil \\
\hline 5 & 35 & 2 & $6-40$ & 10YR 4/1 & sic \\
\hline 15 & 35 & 1 & $0-38$ & 10YR $4 / 3$ & sil \\
\hline 15 & 35 & 2 & $38-50$ & 10 YR $6 / 3$ & si \\
\hline 25 & 35 & 1 & $0-22$ & $10 \mathrm{YR} 4 / 3$ & sil \\
\hline 25 & 35 & 2 & $22-42$ & $10 Y R 6 / 3$ & si \\
\hline 35 & 35 & 1 & $0-25$ & 10YR $4 / 3$ & sil \\
\hline 35 & 35 & 2 & 35.40 & 10YR $5 / 3$ & sil \\
\hline 35 & 35 & 3 & $40-58$ & $10 \mathrm{YR} 6 / 3$ & si \\
\hline 45 & 35 & 1 & $0-30$ & $10 \mathrm{YR} 3 / 2$ & sil \\
\hline 45 & 35 & 2 & 30.50 & $10 \mathrm{YR} 4 / 2$ & sil \\
\hline 15 & 35 & 3 & $50-56$ & 10 YR $6 / 3$ & sil \\
\hline 55 & 35 & 1 & $0-17$ & $10 Y R 5 / 2$ & sil \\
\hline 55 & 35 & 2 & $17-52$ & 10YR $3 / 2$ & sicl \\
\hline 55 & 35 & 3 & $52-60$ & $10 \mathrm{YR} 6 / 3$ & sicl \\
\hline 65 & 35 & 1 & $0-11$ & $10 \mathrm{rR} 5 / 2$ & sicl \\
\hline 65 & 35 & 2 & $11-30$ & 10 YR $6 / 2$ & mixed fills \\
\hline 65 & 35 & 3 & $30-45$ & 10YR 4/2 & sicl \\
\hline 75 & 35 & 1 & $n-9$ & 10YR $4 / 2$ & sil \\
\hline 75 & 35 & 2 & $9-22$ & 10YR 3/1 & sil \\
\hline 75 & 35 & 3 & $22-39$ & 10YR $5 / 1$ & sicl \\
\hline 85 & 35 & 1 & $0-7$ & 10YR $5 / 3$ & ail \\
\hline 85 & 35 & 2 & $7-28$ & $10 \mathrm{YR} 5 / 2$ & sicl \\
\hline 85 & 35 & 3 & $28-41$ & $10 Y R 6 / 3$ & sicl \\
\hline 10 & 40 & 1 & $0-40$ & $10 \mathrm{YR} 4 / 2$ & sil \\
\hline 20 & 40 & 1 & $0-40$ & 10YR 4/2 & sil \\
\hline 30 & 40 & 1 & $0-42$ & 10YR $4 / 2$ & sil \\
\hline 30 & 40 & 2 & $42-50$ & 10YR $5 / 2$ & si \\
\hline 40 & 40 & 1 & $0-37$ & $10 \mathrm{YR} 4 / 2$ & sil \\
\hline 40 & 40 & 2 & $37-45$ & $10 Y R 5 / 3$ & si \\
\hline 60 & 40 & 1 & $0-42$ & 10YR 4/2 & sil \\
\hline 60 & 40 & 2 & $42-50$ & $10 \mathrm{YR} 4 / 2$ & c \\
\hline
\end{tabular}




\begin{tabular}{|c|c|c|c|c|c|}
\hline \multicolumn{2}{|c|}{ COORDINATES: } & \multirow{2}{*}{$\begin{array}{l}\text { STRATUM/ } \\
\text { LEVEL }\end{array}$} & \multirow{2}{*}{$\begin{array}{l}\text { DEPTH } \\
(\mathrm{cm})\end{array}$} & \multirow{2}{*}{$\begin{array}{c}\text { SOIL } \\
\text { COLOR }\end{array}$} & \multirow{2}{*}{$\begin{array}{c}\text { SOIL } \\
\text { TEXTURE }\end{array}$} \\
\hline NORTH & EAST & & & & \\
\hline 70 & 40 & 1 & $0-24$ & $10 \mathrm{YR} 3 / 2$ & sil \\
\hline 70 & 40 & 2 & $24-35$ & $10 Y R 3 / 1$ & sic \\
\hline 80 & 40 & 1 & $0-23$ & $10 Y R 3 / 2$ & sic \\
\hline 80 & 40 & 2 & $23-40$ & $10 Y R 3 / 1$ & c \\
\hline 90 & 40 & 1 & $0-25$ & $10 Y R \quad 4 / 2$ & sil \\
\hline 90 & 40 & 2 & $25-40$ & 10YR 3/1 & $c$ \\
\hline
\end{tabular}

MUNSELL COLOR NOTATIONS

SOIL TEXTURE ABBREVIATIONS

$\begin{array}{ll}\text { 2.5Y 6/4 } & \text { light yellowish brown } \\ \text { 10YR 2/2 } & \text { very dark brown } \\ \text { 10YR 3/1 } & \text { very dark gray } \\ \text { 10YR 3/2 } & \text { very dark grayish brown } \\ \text { 10YR 3/3 } & \text { dark brown } \\ \text { 10YR 4/1 } & \text { dark gray } \\ \text { 10YR 4/2 } & \text { dark grayish brown } \\ \text { 10YR 4/3 } & \text { dark brown/brown } \\ \text { 10YR 4/4 } & \text { dark yellowish brown } \\ \text { 10YR 5/1 } & \text { gray } \\ \text { 10YR 5/2 } & \text { grayish brown } \\ \text { 10YR 5/3 } & \text { brown } \\ \text { 10YR 5/6 } & \text { yellowish brown } \\ \text { 10YR 6/2 } & \text { light brownish gray } \\ \text { 10YR 6/3 } & \text { pale brown } \\ \text { 10YR 6/4 } & \text { light yellowish brown }\end{array}$

$\begin{array}{cl}\text { S } & \text { sand } \\ \text { ls } & \text { loamy sand } \\ \text { sl } & \text { sandy loam } \\ 1 & \text { loam } \\ \text { sil } & \text { silt loam } \\ \text { sicl } & \text { silty clay loam } \\ \text { cl } & \text { clay loam } \\ \text { scl } & \text { sandy clay loam } \\ \text { sic } & \text { silty clay } \\ \text { c } & \text { clay }\end{array}$


APPENDIX D

ARITFACT CATALOG 


\section{ARTIFACT CATALOG}

Catalog No.

Location:

Ceramics:

Total:

Catalog No.

Location:

Ceramics:

Total:

Catalog No.

Location:

Glass:

Total:

Catalog No.

Location:

Glass:

Total:

Catalog No.

Location:

Glass:

Other:

Total:

Catalog No.

Location:

Architectural:

Total:

Catalog No.

Location:

Architectural:

Total:

Catalog No.

Location:

Architectural:

Total:

Catalog No.

Location:

Misc. Metal:

Total:
1

Survey Area \#5, Transect: B, STP: 5, Level: 1

1 red, coarse earthenware body sherd $w /$ white slip underglaze and clear 1 overglaze, exfoliated; hard paste; possible plate or tile frag

2

Survey Area \#1, Transect: I, STP: 26, Level: Surface (Site 16CU205)

1 embossed whiteware/ironstone rim; probable plate

1

3

Survey Area \#1, Transect: I, STP: 28, Level: 1 (Site 16CU205)

1 clear, curved body; indeterminate function

1

4

Survey Area \#1, Transect: J. STP: 27, Level: 1 (Site 16CU205)

1 clear, curved rim w/ tiny molded strations underneath "folded" rim;

1 tumbler or jelly jar

5

Survey Area \#1, Transect: I, STP: 29, Level: 1

1 clear, curved body; probable bottle

2 clear, continuous thread rims; jar or wide-mouthed bottle

1 clear, embossed body w/ seam; machine-made bottle 1 milk glass, embossed rim; possible vase

1 yellow, plastic tube (approx. 1/2" dia.); possible hula hoop

6

Site 16CU205 Gridded STP: N25/E5, Level: 1

21 unid., oorroded nail frags

2 wire nail frags

23

7

Site 16CU205 Gridded STP: N65/E5, Level: 1

3 unid., corroded nail frags

1 wire nail frag

4

8

Site 16CU205 Gridded STP: N20/E10, Level: 2

2 unid., corroded nail frags

3 wire nail frags

5

9

Site 16CU205 Gridded STP: N30/E10, Level: 2

1 corroded iron shaft (?) approx. 7" long \& 1/4" dia. 
Catalog No.

Location:

Ceramic:

Architectural:

Misc. Metal:

Total:

Catalog No.

Location:

Architectural:

Total:

Catalog No.

Location:

Architectural:

Total:

Catalog No.

Location:

Architectural:

Total:

Catalog No.

Location:

Ceramics:

Glass:

Total:

Catalog No.

Location:

Glass:

Architectural:

Faunal:

Total:

Catalog No.

Location:

Architectural:

Total:

Catalog No.

Location:

Glass:

Architectural:

Total:
10

Site 16CU205 Gridded STP: N40/E10, Level: 2

1 plain, whiteware/ironstone body; indeterminate function, water worn 1 wire nail frag

1 unid. flat metal frag

3

11

Site 16CU205 Gridded STP: N25/E15, Level: 2

3 wire nail frags

3

12

Site 16CU205 Gridded STP: N65/E15, Level: 1

1 wire nail

1

13

Site 16CU205 Gridded STP: N50/E20, Level: 1

1 brick frag

1

14

Site 16CU205 Gridded STP: N60/E20, Level: 1

1 plain, whiteware/ironstone rim $w /$ handle lugs; cup

1 brown glazed (int. \& ext.) stoneware body; indeterminate function

1 amethyst, curved body

3

15

Site 16CU205 Gridded STP: N15/E25, Level: 1

1 clear, curved body

1 wire nail frag

1 unid. mammal tooth, burned

3

16

Site 16CU205 Gridded STP: N25/E25, Level: 1

1 slate frag

1

17

Site 16CU205 Gridded STP: N35/E25, Level: 1

1 amethyst, curved hody; indeterminate function

3 clear, curved body; indeterminate function

1 clear, continuous-thread rim w/ seam; machine-made jar

1 green tint, flat

1 wire nail frag

2 unid.; corroded nail frags

9 


\section{ARTIFACT CATALOG}

Catalog No.

Location:

Architectural:

Total:

Catalog No.

Location:

Ceramic:

Total:

Catalog No.

Location:

Glass:

Total:

Catalog No.

Location:

Glass:

Architectural:

Total:

Catalog No.

Location:

Ceramics:

Glass:

Architectural:

Misc. Mctal:

Total:

Catalog No.

Location:

Architectural:

Total:

Catalog No.

Location:

Misc. Metal:

Other:

Total:
18

Site 16CU205 Gridded STP: N75/E25, Level: 1

2 cement frags

2 wire nails

1 unid., corroded nail

5

19

Site 16CU205 Gridded STP: N85/E25, Level: 1

1 plain, whiteware/ironstone body; indeterminate function 1

20

Site 16CU205 Gridded STP: N105/E25, Level: 1

2 clear, embossed body; indeterminate function

2

21

Site 16CU205 Gridded STP: N30/E30, Level: 1

1 amethyst, curved body; indeterminate function

1 clear, curved body; indeterminate function

1 green tint, flat

1 unid., corroded nail frag

4

22

Site 16CU205 Griddcd STP: N40/E30, Level: 1

1 clear glazed (int. \& ext.) stoneware base; probable crock

1 plain, whiteware/ironstone body; bowl or cup

1 medium blue, curved body; indeterminate function

1 amethyst, curved

body; indeterminate function

4 blue tint, flat

5 wire nail frags

3 unid., corroded nail frags

7 unid., corroded semi-flat iron frags

1 flat, malleable lead frag; indeterminate function

24

23

Site 16CU205 Gridded STP: N50/E30, Level: 1

1 wire ruil frag

1 unid., corroded nail frag

2

24

Site 16CU205 Gridded STP: N60/E30, Level: 1

2 hollow iron frags; probable handle

1 charcoal frag

3 


\section{ARTIFACT CATALOG}

Catalog No.

Location:

Ceramics:

Total:

Catalog No.

Location:

Glass:

Architectural:

Misc. Metal:

Other:

Total:

Catalog No.

Location:

Glass:

Total:

Catalog No. Location:

Ceramics:

Glass:

Architectural:

Misc. Mẹtal:

Total:

Catalog No.

Location:

Ceramics:
25

Site 16CU205 Gridded STP: N90/E30, Level: 1

1 plain, whiteware/ironstone body; indeterminate function 1

26

Site 16CU205 Gridded STP: N15/E35, Level: 1

1 brown, curved body; probable bottle

7 clear, curved body; indeterminate function

1 clear, continuous thread rim; bottle

1 clear, curved body; probable lamp chimney

1 blue tint, flat

3 wire nail frags

3 unid., corroded nail frags

4 unid., flat corroded iron frags

1 black, cylindrical piece of carbon (?); indeterminate function

22

27

Site 16CU205 Gridded STP: N25/E35, Level: 1

3 clear, curved body; probable lamp chimney

1 clear, molded curved body; decorative piece (vase?)

4

28

Site 16CU205 Gridded STP: N35/E35, Level: 1

1 flow-blue whiteware/ironstone rim; possible plate

1 plain, whiteware/ironstone body; indeterminate function

1 plain, porcelain rim; possible bowl or saucer

1 embossed whiteware/ironstone rim; plate

6 clear, curved body; indeterminate function

6 clear, curved body; lamp chimney

1 clear, curved rim; lamp chimney

1 clear, base w/ maker's mark \& nos.; bottle

2 clear, embossed base \& body; strawberry jelly jar

3 aquă, curved body; indeterminate function

1 aqua, ground rim w/ screw thread; jar

1 clear, flat

5 blue tint, flat

11 wire nail frags

8 unid., corroded nail frags

1 slate frag

1 brick frag

11 unid., corroded iron frags

57

29

Site 16CU205 Gridded STP: N45/E35, Level: 1

1 plain, whiteware/ironstone rim; plate

1 plain, whiteware/ironstone body; indeterminate function

1 plain, whiteware/irnnstone partial base; indeterminate function 


\section{ARTIFACT CATALOG}

Catalog No. Glass:

Architectural: Misc. Metal:

Total:

Catalog No.

Location:

Glass:

Architectural:

Misc. Metal:

Total:

Catalog No. Loxation:

Glass:

Architectural:

Misc. Metal:

Faunal:

Total:

Catalog No.

Location:

Ceramics:

Architectural:

Total:

Catalog No.

Location:

Ceramics:

Glass:
29--Continued

1 clear, embossed body; probable bottle w/ lettering "St" \& " $\mathrm{T}$ "

1 milk glass, curved body; indeterminate function

1 aqua, curved body; indeterminate function

5 wire nail frags

4 unid., corroded iron

15

30

Site 16CU205 Gridded STP: N55/E35, Level: 1

3 clear, curved body; indeterminate function

1 wire nail frag

6 unid., corroded iron frags

1 corroded wire, circular

11

31

Site 16CU205 Gridded STP: N65/E35, Level: 2

1 brown, curved body; probable bottle

3 clear, curved body; indeterminate function

1 clear, body w/ thread near rim; probable jar

1 clear, embossed curved body; indeterminate function

6 wire nail frags

2 unid., corroded nail frags

4 unid., corroded iron frags

1 small bivalve shell

19

32

Site 16CU205 Gridded STP: N75/E35, Level: $1 \& 2$

1 plain, whiteware/irnnstone shoulder; platc or shallow bowl

1 wire nail frag

2

33

Site 16CU205 Gridded STP: N20/E40, Level: 1

1 plain, whiteware/ironstone body; bowl or cup

1 plain, whiteware/ironstone base $\mathrm{w} /$ flat foot ring; plate

1 plain, whiteware/ironslune body; plate

1 embossed, whiteware/ironstone rim; indeterminate function

1 brown underglazed band, whiteware/ironstone body; indeterminate function

5 brown, curved molded body; probable bottle

1 brown, curved body w/ seam; probable bottle

3 cobalt, curved body $(1 \mathrm{w} /$ seam); indeterminate function

1 milk glass, curved molded body; decorative piece

1 clear, frosted glass base; probable bottle

50 clear, curved body; indeterminate function

1 clear, continuous-thread rim; jar

3 clear, base ( $1 \mathrm{w} /$ maker's mark \& no.); jar or bottle

3 clear, partial necks $w /$ threads; 


\section{ARTIFACT CATALOG}

Catalog No.

Architectural:

Misc. Metal:

Faunal:

Other:

Total:

Catalog No. Location:

Ceramic:

Glass:

Architectural:

Other:

Total:

Catalog No.

Location:

Ceramic:

Glass:

Faunal:

'l'otal:

Catalog No.

Location:

Ceramic:

Glass:

Architectural: Misc. Metal:

Faunal:

Total:
33--Continued

3 different bottles [ 1 clear, rim; jelly jar or tumbler 2 clear, curved embossed body (one w/ letter " $S$ "); indeterminate function]

1 clear, curved body w/ white painted letters "SU" \& "PU"; probable bottle

1 clear, neck w/ molded ridges; probable bottle

2 wire nails

1 unid., corroded nail frag

5 brick frags

4 unid., corroded iron frags

2 bivalve shell frags

7 turtle carapace

1 tar frag

100

\section{4}

Site 16CU205 Gridded STP: N40/E40, Level: 1

1 polychrome, underglaze decalcomania whiteware/ironstone body; indeterminate function

1 embossed whiteware/ironstone rim; indeterminate function

1 plain, whiteware/ironstone rim; indeterminate function

1 plain, whiteware/ironstone rim, exfoliated; indeterminate function

1 plain, whiteware/ironstone body; indeterminate function

1 buff, yellow ware body w/ wide brown glazed band ext. \& same brown glaze int.; probable bowl

4 amethyst, curved body ( $2 \mathrm{w} /$ seams); indeterminate function

1 blue tint, curved body embossed with letter " $\mathrm{H}$ " (?)

1 wire nail

1 phonograph record frag

13

35

Site 16CU205 Gridded STP: N60/E40, Level: 1

1 clear glazed, gray stoneware base; possible crock

2 clear glazed, gray stoneware body; possible crock

2 clear, curved body ( $1 \mathrm{w} / \mathrm{seam})$

3 oyster shell frags ( 1 complete half) 8

36

Site 16CU205 Gridded STP: N70/E40, Level: 1

1 plain, yellow ware rim; bowl

4 clear, curved body ( 2 w/ seams); bottle

1 clear, rim w/ lug closure; machine-made jar

1 clear, continuous-thread rim \& neck; mas.hine-made bottle

1 brick frag $w /$ cement attached

1 iron scissors

4 small bivalve shells

13 
APPENDIX E

CONTRACT SCOPE OF WORK 


\section{CONTRACT \\ PART I \\ SCOPE OF WORK}

\subsection{DESCRIPTION OF WORK - GENERAL}

1.1 Except as otherwise expressly provided in the subcontract, the Subcontractor shall supply all labor, supervision, materials (installed and consumable), consultation, services, testing devices, facilities and each and every item of expense necessary for the completion of the Culture Resource Investigation hereinafter called the Work.

\subsection{SPECIFICATIONS, DRAWINGS AND EXHIBITS}

All Work shall be performed in strict accordance with the following described specifications, drawings and other documents, which by this reference are made a part hereof.

\subsection{Drawings}

Drawing No.

WH-C-510-3

\subsection{Exhibits}

Exhibit No.

One

Two

Three

Four

Five

$06 / 10 / 85$
Date or

Rev. No.

$09 / 01 / 85$

C

1

Title

Pipeline Location Map 
Six

Seven

Eight

Nine

Ten

Eleven

Twelve
$02 / 25 / 87$

$07 / 01 / 84$

$06 / 80$

$09 / 29 / 83$

$10 / 12 / 82$
Subcontract Security Provisions

Contract Activities Daily Report

Unit Rate Schedule

36 CFR 800

Cultural Resources Code of Louisiana Chapter III Exccrpts

48 CFR 190 - Guidelines

for Archaeological

Documentation

Manual of Mitigation

Measures (MOMM)

\subsection{DESCRIPTION OF WORK - SPECIFIC}

The purpose of this study is to assist the U.S. Department of Energy in its cultural resource investigations in the Distribution Enhancements Project in Calcasieu and Cameron Parishes, Louisiana. Survey recommendations have been received from the State Historic Preservation Officer (SHPO) and are incorporated into the Scope of Work. Specific maps and aerial photographs of the boundaries of the study area will be furnished to the Subcontractor at start of Work.

Cultural resource investigations will be in compllance with Section 106 of the National Historic Preservation Act, 36 CFR 800, and the Manual of Mitigation Measures (MOMM). The Subcontractor is to provide for: 1) archival and historic research; 2) intensive survey (Level II);3) site testing and excavation; 4) laboratory analyses; 5) progress reports; 6) technical reports; 7) completion of forms required by the State Historic Preservation Officer; and 8) options as stated in paragraph 3.3.6.

\subsection{Description of Project}

The area to be surveyed for cultural resources will be within the proposed perpetual easement and temporary construction zone, collectively termed as the right-of-way (ROW).

The (ROW) may be defined as that area consisting of a perpetual easement plus a temporary construction zone. Normally the ROW will be a total of $125 \mathrm{ft}$. wide. However, at major crossings, the total will be greater due to additional construction zones required. The ROW is approximately thirteen miles in length. 


\subsection{Description of Project Area}

The proposed pipeline route crosses farmland, pastures, marshland and numerous water courses. Current land use in the project area includes residential, agricultural, recreational, industrial, developed oil/gas fields, roads, drainage ditches, and numerous pipelines.

The present cultural resources study will address historic as well as prehistoric resources. Previous land uses in the region have included camps and habitation sites of early settlers, explorers, and coastal aboriginal tribes. It is anticipated that aboriginal sites may be present in areas of pimple mounds and near or adjacent to water courses, freshwater ponds and lakes, especially in areas of higher elevation.

\subsection{Statement of Work and Methodology}

The work to be accomplished shall consist of major task areas listed as follows:

\subsubsection{Archival/Historic (Literature) Research}

\subsubsection{Prepare Field Survey Plan}

3.3.3 Cultural Resources Field Survey (Level II)

\subsubsection{Reporting}

3.3.5 Meeting Attendance (up to four) with Fluor, DOE and/or SHPO either in Baton Rouge, New Orleans, or Houston

\subsubsection{Options for Consultation and Alternate Route Study}

\subsubsection{Disposition of Original Records and Artifacts (Subsection 9.4)}

Should Fluor elect to study alternate routes, the Statement of Work and Methodology will be employed by the subcontractor.

Elaboration on each task description is presented in the following Section (3.4) on Methodology. The Methodology listed below is a statement of minimum study requirements.

\subsection{Methodology}

3.4.1 Archival/Historic (Literature) Research

Archival/historic research of the entire pipeline route will be accomplished by utilizing aerial photography, existing/past studies, pertinent maps, records, and local informants to obtain necessary information. Information from the Louisiana State Historic Preservation Office (SHPO) on known sites will be made available at their 
offices in Baton Rouge to the subcontractor on sites and potential sites within the $125 \mathrm{ft}$. of the right-of-way (ROW) of the DOE pipeline. The Subcontractor is responsible for obtaining this data from the SHPO.

Research information from this effort will be used during the study and summarized in the technical report. Information will also assist in identifying field survey areas.

\subsubsection{Field Survey Plan}

The subcontractor shall prepare, develop, finalize and submit a Field Survey Plan to Fluor within five (5) calendar days following award of Subcontract. Included in the Field Survey plan will bo a project schedule, work plan, statement of detailed study, methodology and logistics to be employed. The Field Survey Plan shall be a plan of action to complete project tasks stated within the Scope of Work in accordance with Section 7.0 - Performance Schedule and Sequences of Work.

The subcontractor must be prepared to present and discuss methods and findings to the Louisiana SHPO in Baton Rouge during the survey investigation.

Prior to commencing field activities, the subcontractor. must have a Survey Plan which has been approved by Fluor.

\subsubsection{Cultural Resources Survey}

\section{a. Field Survey}

The survey will consist primarily of an intensive field survey (Level II). This level of investigation involves a complete, thorough, on-the-ground survey and testing of an area sufficiently to determine the number and extent of the resources present; their cultural and scientific importance; and a comprehensive plan for preserving, recovering, or otherwise mitigating adverse effects on them.

b. Level II investigations consist of an intensive and extensive primary literature and records review and evaluation, an on-the-ground inspection of the project area including mapping, photographing, controlled surface collecting, soil auger and shovel testing, and other procedures necessary to collect the data specified in paragraph 3.4.3. Where no cultural remains are apparent on the surface of high probability areas, augering, coring, or shovel testing, with screening, shall be done at regular intervals. In the case of historic sites, magnetometers and other appropriate geophysical devices shall be employed for locating 
buried foundations and other subsurface features. The first phase additionally consists of recording extant. above ground cultural resources (districts, buildings, objects and sites). Photographs shall be included and brief descriptions of those salient features which cannot be treated properly through photographic techniques. Examples of such features include, but are not limited to, underlying structures and interior details and the cultural setting of the property or district.

c. Limited test excavations at known archaeological sites shall be conducted where additional information is required to support either: 1) eligibility determinations for the National or State Registers, or 2) feasibility and methodological appraisals to be used in mitigation. At this level of survey, samples requiring special analysis, including absolute dating samples (i.e., C-14, etc.) shall be collected as appropriate. The project budget shall include sufficient funds for the analysis and interpretation of the samples. The Principal Investigator shall justify the criteria used and document why each site does or does not meet the State Registry criteria, as expressed in 36 CFR 800.10.

d. All areas surveyed and the degree of coverage shall be precisely noted on 7.5 minute USGS topographic quadrangle maps. Detailed survey notes shall be kept by the survey crews with separate descriptions of each area including soils, topography, vegetative cover, the number, spacing, and depth of shovel tests, and findings.

e. The subcontractor will survey/assess the entire rightof-way along the specified portions of the proposed route with the following exceptions:
1. In areas where $D O E$ has an easement within an existing construction corridor, only width of DOE's easement shall be surveyed;

f. Should the subcontractor determine in the field that portions of DOE's right-of-way or easement are so heavily disturbed by existing development that no cultural resources will be present, with Fluor's agreement, no survey needs to be conducted. However, in such cases, the precise areas left unsurveyed must be indicated on the 7.5 minute USGS Quadrangle and the disturbance documented with black and white glossy photographs.

Methodology will be in accordance with paragraph 3.4.3.C. 
g. Should the archival/historic research effort indicate areas of high probability of presence of cultural resources, then a field reconnaissance will be conducted to determine whether further study is warranted. In the field, best professional judgement should be employed in selecting testing sites.

Methodology will be in accordance with Field Survey Methods (Paragraph 3.4.3).

h. Cultural resources are defined as any building, site structure, object, data or other material significant in history, architecture, science, archenlogy, or culture. All cultural resources identified, historic and prehistoric, shall be recorded. Materials of any obvinusly recent and insignificant nature (e.g. recent trash) may be noted in the field journal but shall not be exhaustively recorded and pursued as cultural resources nor addressed in the final report. Sites shall be thoroughly documented and recorded on State of Louisiana site forms. All sites shall be precisely located on appropriate 7.5 minule USGS topographic maps and assigned State trinomial site numbers. Both the configuration and actual extent of the sites shall be indicated on the maps. All testing that is undertaken shall be done in a professional manner and shall be fully documented and reported.

i. A complete photographis record ineluding black and white prints shall be kept and shall be used to record identified cultural resources, the general topography and condition of the project area at the time of survey, and the field techniques and methodology employed by the subcontractor. All photographs shall be documented as to date, location, vantage point and subject of the photograph. This documentation shall be recorded in the photographic Iog, and on one cupy of each phatograph produced under this Subcontract. Thoroughly documented and cataloged photographs shall be submitted with the other field data and documentation for curation. Alt photographs submitted for the final report shall be black and white and printed on medium weight glossy finish paper.

j. Testing shall be conducted in all high site probability areas, and at regular intervals (not to exceed 100 meters) in areas where vegetative cover obscures the ground surface. Screening (e.g., $\frac{1}{4}$ inch mesh) of materials may be necessary to recover cultural remains. Testing of sites shall be as least destructive as possible. Detailed notes of testing shall be kept and shall allow future researchers to determine the extent and general location of testing at each site, 
stratigraphy identified, features observed, and artifacts recovered.

k. Subcontractor field activities will be monitored and inspected by fluor and the federal government. A detailed daily journal of all project activities shall be kept and will be open to inspection at any time during the subcontract period. All notes, site forms, and journals must be legible and of sufficient detail and clarity to be of use to future researchers. These records shall be submitted with the draft report for review by fluor. All measurements shall be made in the metric system.

1. The subcontractor shall take reasonable precautions to assure the safety of the crew at all times. In addition, precautions shall be taken to avoid drawing attention to sites discovered during the survey to preclude additional pothunting. The subcontractor shall initiate no publicity concerning the work, and shall direct all such inquiries to Fluor's Environmental Manager.

m. The analyses of materials resulting from the survey and site testing may include historic artifacts, ceramic, faunal remains and lithics. All historic artifacts collected or recorded during the field survey shall be identified, described by appropriate categories (e.g. metal, glass, ceramic, wood), and dated, in-so-far as it is possible to do so. Materials that are obviously less than 50 years old shall not be included in the analysis. The subcontractor is expected to be conversant enough with typical historic artifacts recovered from sites in Louisiana to be able to distinguish between modern trash and materials of historic interest. Sufficient data will be analyzed to evaluate the site for National Register eligibility.

n. When a site containing potential fistoric or prehistoric evidence of human activity is located, the subcontractor must:

1. Comply with paragraph 3.4.4 and Exhibit Four, Site Data Provisions;

2. Conduct sufficient testing to determine the horizontal and, if possible, the vertical extent of the site;

3. Photograph the site areas using black and white glossy prints; 
4. Determine on a preliminary basis the site's potential National Register significance from the information obtained through the testing.

Sufficient data will be collected to allow the SHPO in consultation with Fluor and the Government to evaluate potential National Register eligibility;

5. Complete State of Louisiana Archaeological Site Data Form; and

6. Contact Fluor Environmental Manager within thirty-six hours when any site of potential National Register significance is discovered.

7. Be prepared to discuss and present data to the SHPO in Baton Rouge, Louisiana in support of Fluor and the Government on this project.

\subsubsection{Site Data}

The relevant scientific data itemized below shall be collected at each site visited during the cultural resources investigation and recorded on SHPO site forms. The Principal Investigator at the investigation shall fully justify in writing the reasons for deletion of all data categories not addressed.

\section{a. Physical Setting}

1. Terrestrial Sites:

a. Landform - at present and at time of occupation if different from the present;

h. Dominant geomoriphic processes at time of occupation and afterward;

c. Elevation (meters above/below sea level) and relief;

d. STiope;

e. Flooding - time of year, extent, and duration;

f. Soil associations;

g. Nearest water - name of water body, type of water, and distance from site;

h. Site position with respect to terrain specify stream bank location (cutbank, point 
bar, reach), position with respect to stream junctions, and other associations such as terrace margin or natural levee;

i. Floral and faunal communities at time of occupation, if possible, or present communities as a model for those at time of occupation;

j. Site location with respect to other sites list site number and distance of nearest known site (linear and water connective distances in metric measurements), and also the distance and number of the nearest known site of comparable age.

2. Underwater Sites:

a. Bottomform - at present and at time of occupation;

b. Dominant geomorphic processes at time of wreck or occupation and afterward;

c. Thickness of sediment cover;

d: Depth (meters below sea level) and relief;

e. Bottom slope;

f. Water conditions - current, visibility, salinity, $\mathrm{pH}, \mathrm{O}_{2}$;

g. Association with other drowned relict features;

h. Bottom floral and faunal communities;

1. Site location with respect to other sites (underwater or terrestrial) - list site number and distance of nearest known site of comparable age.

\section{b. Site Description}

1. Archäenlngical Sites:

a. Site size, plan, orientation;

b. Stratigraphy - shown by a detailed profile drawing and description of soil zones or, as a minimum, an estimate of the vertical 
dimensions of the site determined by soil augering or posthole testing;

c. Density of cultural materials by class (e.g., $*$ bone, stone, fired clay) and intrasite provenience of cultural materials;

d. Artifacts inventory 1 ist, measurements, photography, and maps of cultural features;

e. Classification scheme used to describe objects;

f. Present use and condition of site.

2. Architectural Sites More Than Forty Years 01d:

a. Site size, building floor plan and orientation;

b. Type of property = o.g., residence, barn, store, etc.;

c. Date or period of construction;

d. Common or historic name of property;

e. Notable or distinguishing features (i.e., decorative details, oddities, or unusual characteristics);

f. Histortcal significance;

g. Photographs - a minimum of two photographs showing front, back and two sides and photographs of significant interior features, if any.

\subsection{Options}

Consultation to the project may occur during construction phases and may include additional unidentified tasks. Payment for consultant services will be based on unit rọtes stated in PART II.

\subsection{DELIVERABLES/REPORT/TECHNICAL REPORT}

4.1 All reports shall be submitted with a cover letter to Fluor Engineers, Inc. Texoma Distribution Enhancements Project, Project Manager.

4.1.1 The Subcontractor shall prepare a comprehensive draft report detailing the work accomplished, the study rationale, and study results. The draft shall be a complete 
professional document and an accurate representation of the content of the final report. All photographs and graphics such as maps, charts, tables, and drawings must be complete and included in the draft report.

4.1.2 The report(s) shall include information listed as follows:

a. For reports of cultural resources surveys in which sites are located, the following items shall be included:

1. Preliminaries - title page, abstract, table of contents, list of figures, list of tables, preface (to include the name of the Principal Investigator and other survey personnel, and the funding and/or sponsoring agency);

2. Summary - brief statement outlining the results of the survey and the Principal Investigator's recommendations. Included shall be the number of sites affected, whether the affected sites are eligible for inclusion in the National and/or State Registers, recommendations for further work and time required for that work and any other recommendations the contractor or Principal Investigator may have;

3. Nature and distribution of major environmental components in the project area;

4. Culture history relevant to the area of study;

5. Previous archaeological, historical and architectural investigations which are relevant to the survey;

6. Description of the survey - type of investigation, delineation of the survey area (with map), research design, survey methods, map showing those areas actually inspected on the ground, and comments;

7. Site descriptions - brief description and evaluation of each site, with site data specified in paragraph 3.4 .4 above;

8. Analyses and interpretations;

9. Biblingraphy;

10. Appendix which includes evaluations of sites for inclusion in the Registry of State Landmarks or the National Register of Historic Places, vitae of 
Principal Investigator and supervisory personnel, and copy of the Scope of Work;

11. Two copies of Departmental site forms for all sites visited, including state site number, maps, photographs and supporting data, shall be submitted to the Secretary under separate cover and marked "Confidential." Each site form must contain the official state site number assigned by the Department.

b. For reports of surveys in which no sites are incated, the following items shall be included:

1. Preliminaries - as required by a(1) above;

2. Summary - as required by $a(2)$ above;

3. Description of the environment of the survey area as in Section b above;

4. Culture history, previous investigations, and description of survey;

5. Principal Investigator's comment on the possible reasons why no sites were discovered;

6. Bibliography:

7. Appendix - as required by a(10) above.

c. For archaeological testing and excavation reports, the following items shall be included:

1. Preliminaries - as required by a(1) above;

2. Sumary - brief statement outlining the results of the excavation;

3. Nature and dfstribution of major environmental components in the project area;

4. Culture history as it relates to the investigation;

5. Previous investigations at site, if any;

6. Description of the excavation with maps, profiles, photographs, etc.;

7. Analysis of the recovered remains;

8. Interpretation of the remains; 


\section{Bibliography; \\ 10. Appendix - as required in a(10) above.}

d. For full recording of architecturally significant buildings and structures:

1. Preliminaries - as required by a(1) above;

2. Summary - brief statement outlining the resuits of the study;

3. Previous recording, if any;

4. History of building;

5. Historical data, measured drawings, and photographs following HABS/HAER standards;

6. Bibliography;

7. Appendix - as required in a(10) above.

Subcontractor shall show the Fluor Subcontract Number and identifying item numbers, if applicable, on all data submitted pursuant to Subsection 4.1 above.

\subsubsection{Report Format}

Reports of investigations shall be prepared in a format reflecting contemporary standards in accordance with Section 4.1.2 and as otherwise directed in accordance with coordiantion meetings.

Draft reports shall be double spaced. The draft may be photocopied and unbound. Photographs, plates, drawings, and other graphics shall appear in the same size, format, and general location in the draft report as they will appear in the final report. These graphics may also be reproducsd by a high auality photocopier which produces an accurate representation of the original.

The layout of the final report shall conform to requirements to permit the report to be an overall size of $8-1 / 2$ " $x$ 11". No oversized materials will be accepted in the final report. The layout shall include camera-ready pasteup of text and all related materials. The test shall be single spaced with all pages of the text numbered and printed on both sides. Photographs, plans, maps, drawings, and text must be clean and clear. Final copies will be bound in perfect binding. One unbound final copy will be submitted to fluor for inclusion into the NTIS System. 


\subsubsection{Report Distribution}

The subcontractor shall submit ten (10) copies of the draft. report, and twenty (20) printed copies and the camera-ready original of the final report to the Fluor Project Manager.

\subsection{State of Louisiana Archaeological Site Data Forms}

Site forms (Exhibit Four (4)) shall be completed by the subcontractor in accordance with SHPO requirements. The site forms shall be included in the appendices of the Technical Report (Subsection 4.1).

\subsection{National Reqister Nominations Forms}

On a11 sites deemed eligible for the National Register, all Nomination Forms will be completed and submitted to Fluor. Fluor will provide a listing to the subcontractor of the pripertles decmed eligible.

National Register Nomination Forms shall be completed by the subcontractor in accordance with SHPO standards and requirements of this Subcontract. Sufficient data shall be presented to allow the SHPO in consultation with the SPR to evaluate potential National Register eligibility.

\subsection{Field Survey Plan}

The Field Survey Plan, prepared per Section 3.4 .2 shdll be included in the appendices of the Technical Report (Section 4.1).

\subsection{Survey Field Maps}

These maps will be provided to the subcontractor. U.S.G.S. topographic quadrangle maps will be employed to accurately locate sites and study areas. All sites shall be precisely located on these maps and assigned State of Louisiana numbers. Both the configuratiun and actual extent of the sites shall be indicated on the maps. The maps shall be included within the appendices of the Technical Report (Subsection 4.1).

\subsection{Determination of Effect Report}

For each National Register or eligible property, the Subcontractor (in compliance with 36 CFR 800.4 , see Exhibit Nine (9) shall determine whether the pipeline project will have an effect upon the historical, architectural, archaeological or cultural characteristics of the property. Although contents of this deliverable may be otherwise contained within the Technical Survey Report, separate Determination of Effect Reports are required under this Subcontract. 


\subsection{MATERIAL, EQUIPMENT OR SERVICES FURNISHED BY FLUOR}

Fluor shall furnish or cause to be furnished to Subcontractor, without cost to Subcontractor, the following items for or in connection with performance of the Work:

5.1 Pipeline Route Survey Sketches (Aerial mosaic of Pipeline route, part of aerial photography may be 1 inch $=200$ feet. All sketches are to be returned to fluor at the conclusion of the Work.

5.2 Access or access permits (keys) to site for field work.

5.3 Portions of the proposed DOE/SPR Pipeline Route which will require a 100 percent pedestrian cultural resources field survey shall be delineated on 7.5 minute USGS Topographic Quadrangle maps. Approximate locations of foreign pipelines will be marked on aerial photographs to assist in identifying previously disturbed areas with in the ROW.

5.4 The entire route has been staked in the field by OOE along the centerline of the permanent right-of-way. Fluor will provide assistance if some stakes are missing.

5.5 Fluor shall provide 7.5 minute USGS Topographic Ouandrangle maps.

5.6 Fluor minimum safety requirements and copy of any additional safety requirements imposed by land owners.

5.7 Fluor will arrange for any owner representatives required to accompany subcontractor during his investigation period across the ir land.

5.8 Payment and temporary easement widths.

\subsection{FACILITIES}

\subsection{Furnished by Subcontractor}

Subcontractor shall, as a part of the Scope of Work, supply and properly maintain all facilities necessary for full and complete performance of the Work. Such items shall include, but not necessarily be limited to, those listed below:

\subsubsection{Office space.}

6.1.2 All transportation including boats or marsh buggy, if required.

6.1.3 All fuels and lubricants.

6.1.4 Communication facilities.

6.1.5 Typing, copying, computer use, printing, and binding. 
6.1.6 All consumable supplies of whatever nature.

6.1.7 Any and all tools, instruments and supplies.

6.1.8 Containers, ice, cups and drinking water.

6.1 .9 All required safety equipment.

6.1.10 All other items in performance of the Work.

\subsection{PERFORMANCE SCHEDULE AND SEOUENCE OF WORK}

7.1 Subcontractor shall commence performance of the Work within seven (7) calendar days after receiving Notice to Rruceed froiil Fluor and shall complete the work upon submittal of all Fluor approved final reports and transmittal of collected artifacts to the SHPO. The subcontractor shall submit within fifteen calendar days from the date of receipt of Notice to Proceed a detailed event time sequence schedule showing estimated dates for starting completing work task.

7.2 The schedule for Subcontractor performance of tasks and sequence of work will be developed by the Subcontractor in accordance with the statement of work and methodology (Subsection 3.3). The schedule may be refined within two weeks following subcontract award.

Milestones:

1. Award of Contract/Notice to Pronceed.

2. Complete archival research within fourteen days following Notice to Proceed.

3. Notice to Proceed with field study fourteen days after award.

4. Complete Field Survey - Twenty-eight salendar days fol= lowing award.

5. Complete Oraft Survey Report and Oraft Determinatinn of Fffect - Fifty caleriddr days tollowing award.

6. Submit. SHPO Final Survey Report and Final Determination of Effect Reports to Fluor/SPR for approval fuurteen calendar days following receipt of final comments.

\subsection{REPORTING REQUIREMENTS}

Subcontractor shall submit the schedules and reports set forth below in accordance with the line item requirements.

8.1 Daily Activities Report (Field Activity Only).

8.2 A field log book will be maintained by the Principal Investigator to record field activities. Daily entries will include areas sur- 
veyed during the day, findings of tests, and all items of significance or of potential significance based on project scope of work and professional judgement. The field log book (original) will be given to Fluor at the conclusion of the Work.

\subsection{All documentation as required by Scope of Work, Article 3.0,} PART I.

8.3 A weekly summary report showing scheduled progress versus actual progress giving details of how the Work will be completed in relation to the schedule. The report will also summarize field activities from the previous week such as findings of significance, completion of required forms and any matters of concern regarding the investigation. The report will be submitted to Fluor's Environmental Manager with a copy to Fluor's Contract Engineer. Length of this report (typewritten) may be three pages or less.

\subsection{OTHER REQUIREMENTS}

9.1 Progress Meetings. Meetings shall be held whenever requested by FTuor or the subcontractor for discussion of questions and problems relating to the work required under the Subcontract. These meetings may be held at the site, the fluor facilities or at the Subcontractor's office.

9.2 Inspection and Coordination. During the Subcontract period, the Subcontractor shall confer as necessary to insure timely execution of the work. At times of inspection by fluor on the premises of the Subcontractor, the Subcontractor shall provide all reasonable facilities and assistance for the safety and convenience of the Fluor representatives in the performance of their duties. All inspections and evaluations will be performed in such a manner as will not unduly delay the work.

In addition, the Subcontractor shall cooperate fully with the Louisiana SHPO, allowing them access to field records and field visitations upon request of that office. Up to four coordination meetings with the Louisiana SHPO, "the U. S. Government", Fluor and the subcontractor may be scheduled during the study to review findings of the project, as necessary.

9.3 Confirmation Notices. Close coordination will be maintained between the Principle Investigator (PI) and Fluor to insure that Fluor's best interest is served. The Subcontractor's field director shall maintain close coordination with Fluor Environmental Manager during this subcontract. The Subcontractor shall provide a record of all conferences, meetings, discussions, verbal directions, telephone conversations, etc. on matters relevant to the work wherein the subcontractor or his representative participate with representatives of Fluor. These records, entitled "Confirmation Notices," shall be numbered sequentially and shall fully identify persons participating, subject discussed, and conclusions reached, if any. The Subcontractor shall forward to Fluor, within five work days, a reproducible copy of each confirmation notice. 
9.4 Disposition of Original Records and Artifacts. All artifacts, materials, documents, negatives, recordings, field and laboratory descriptive and analytic notes, as well as all other primary and secondary data obtained in fulfillment of the requirements of this subcontract, are the property of the United States Government. All such materials shall be transmitted by the Subcontractor to the Division of Archaeology - SHPO office in Baton Rouge following acceptance of the final report. All data shall be prepared for curation and cataloged by the Subcontractor in a manner which will facilitate management for preservation and research. The processing and cataloging of materials shall be coordinated by the Subcontractor with the curational facility accepting the collection and approved by fluor. A cummulative inventory of these materials shall be submitted with the final report. The subcontractor is reminded that the field journal and records must be submitted for review along with the draft report.

\subsection{Submittal Specifications}

The Subcontractor shall submit ten copies of the complete draft report within fifty calendar days after contract award. The draft report shall be complete with a 11 tables, charts, and illustrative materials included. The draft report must be legible and edited for technical and grammatical errors. A clear, concise technical writing style shall be used for the report. Contributions by different authors must be edited for consistency of terms and writing style and smooth transition from one section to the next. incomplete, illegible, ur unedited reports will not be accepted and will be returned to the Subcontractor for revision prior to Fluor's formal review and coordination. Upon acceptance of a draft report, a formal raview and coordination of the report will be undertaken by Fluor and the Government. The draft report will be submitled by the Goverrment to the Louisiana SHPO for review and comment. The comments will be combined with those of fluor and formally submitted to the Subcontractor for incorporation into the final report.

Fluor shall have a maximum of thirty calendar days to review the draft report. The Subrinntractor shall have cuurteen calendar days to include Fluor's review/comments in the final report and submit twenty bound copies of the final original report, with all maps, charts, tables, and standard drawings to the Government. In addition, the Subcontractor will submit one camera ready original final report to Fluor.

9.6 Meetings - Louisiana SHPO in Baton Rouge, Loulsiana

The subcontractor shall be prepared for meetings with the SHPO in Baton Rouge, Louisiana.

Anticipated meetings are listed as follows: 
9.6.1 Present and discuss final Field Survey Plan to the SHPO prior to commencing field effort.

9.6.2 Participate in interim coordination meetings as needed.

9.6.3 Present the draft Technical Report verbally to the SHPO.

9.6.4 Present and discuss site data with the SHPO.

\subsection{PRECEDENCE}

10.1 In cases of express conflict between PARTS of the Subcontract, specifications, drawings or exhibits, the order of precedence shall be as follows:

\subsubsection{Signature Document}

10.1.2 PARTS I, II and IV

10.1.3 PART III, General Terms

10.1.4 Drawings

10.1.5 Exhibits

10.2 In the event of an express conflict between the documents listed in Subsection 10.1, or between any other documents which are a part of the Subcontract, Subcontractor shall notify Fluor immediately and shall comply with Fluor's resolution of the conflict.

\subsection{COMMUNICATIONS}

Ali communications pursuant to or in connection with this Subcontract shall be identified by the Fluor Subcontract Number and shall be communicated as set forth below:

\subsection{Subcontract Notices}

All subcontract notices given under this Subcontract shall be sufficient if in writing and delivered in person to an officer of the party to be notified, or sent to the party to be notified, addressed as set forth below, by registered mail, telex or cable. Telexes and cables must be confirmed in writing within three days thereafter.

Subcontract notices to Fluor shall be addressed to Fluor's Home Office Address set forth here in and marked Attn: Contracts Engineer. Subcontract notices to Subcontractor shall be addressed to Subcontractor's Address set forth herein marked Attn: Mr. Charles H. LeeDecker. 
11.1.1 Fluor's Home Office Address:

Fluor Engineers, Inc.

Houston Engineering Center

P.O. Box 5014

Sugar Land, Texas 77487-5014

Attn: Contracts Engineer (412202)

11.1.2 Subcontractor's Address:

Berger, Barnard \& Thomas Engineering, Inc.

4440 North Boulevard

Baton Rouge, Louisiana 70896

Attn: Mr. Charles H. LeeDecker

11.2 A11 communications regarding Daily Activity Reports, invoices, pricing, and take-off, insurance and other administrative requirements shall be submitted to the Home Office and marked Attention: Contracts Engineer (412202).

11.3 All communications regarding technical requirements including technical reports are to be submitted to the Home Office and marked Attention: Environmental Manager (412202) with a copy to the Contracts Engineer (412202).

END OF PART I 
APPENDIX F

STAFF RESUMES

F-1 
NAME :

EDUCATION :

PROFESSIONAL

AFPILIATIONO :

EXPERI ENCE :

1986 to Present:

1985
John A. Hotopp

Ph.D., Anthropology, University of Iowa, 1978 .

University of Colorado, 1969.

M.A., Political Science, Marshall

University, 1968 .

B.A., Economics and Political Science, Morris Harvey College, 1963.

West Virginia University, 1961.

Soclety of Amerlcan Anthropology

Society for Historical Archaeology

Society for Industrial Archaeology

Plains Anthropologist

Sigma Xi

* Vice-President, Berger, Barnard \& Thomas Engineering, Inc.; Principal Archaeologist and Director, The Cultural Resource Group.

Project Director, Assay Archaeological Site Analysis and Report, New York, for. the Howard Ronson Organization, New York.

Project Director, Greinbelt station Arohacological Teoting of the Washington Metropolitan Transit Authority, Washington, D.C.

Principal-In-Charge, Ft Drum Archaeological Testing and Mitigation Project, Watertown, New York, for the National Park Service, Mid Atlantic Region.

* Assistant Vice presldent, Louis Berger \& Associates, Inc.; Principal Archaeologist and Director, The Cultural Resource Group.

project Director, Fort Drum Cultural Resource Inventory, Evaluation, Recording and Management Planning, Watertown, New York, for the National Park Service, MidAtlantic Region and the U.S. Army. 
Project Director, National Archaeological and Cultural Resource Database data collection in 17 states, for the National Park Service, Preservation Services Division.

Project Director, Forts Totten and Hamilton Cultural Resource Overview and Management Plan, Brooklyn and Queens, New York, for the National Park Service, Mid-. Atlantic Region.

Project Director, Stage IA Cultural Resource Investigations of the site of a proposed guest house, Governor's Island, New York, for the Third Coast Guard District.

Project Director, Assessment of Cultural Resource Potential, Harsimus Cove South Development, Jersey City, New Jersey, for Dresdner \& Associates, Inc.

Project Director, Phase I and II Cultural Resource Survey, Somerset Expressway corridor, Somerset County, New Jersey, for the New Jersey Department of Transportation.

Project Director, Phase III Mitigation at the Hamlin Historic Archaeological Site, Mercer County, New Jersey, for the New Jersey Department of Transportation.

Project Director, Archaeological Survey and Testing of the Route 1 corridor, Mercer and Middlesex Counties, New Jersey, for the New Jersey Department of Transportation.

Project Director, Fort Wadsworth Cultural Resource Investigations, Fort Wadsworth, Staten Island, New York, for Wallace, Roberts \& Todd; Michael Baker, Jr., Inc.; and the Department of the Navy, Northern Division.

Project Director, Archaeological Investigations at the Jacob Adriance House, Bellerose, Queens, New York, for the City of New York, Department of Parks and Recreation. Cultural Resource Group, Louis Berger \& Associates, Inc. 
Project Director, Howard Road Archaeological and Architectural Mitigation,

Anacostia Station, Washington, for the Washington Metropolitan Transit

Authority.

Project Director, Forts Hamilton and Totten Cultural Resource Survey and Management Plan, New York, for the National Park Service, Mid-Atlantic Region.

Project Director, Camp Lejeune Phase II Testing, Camp Lejeune, North Carolina, for the U.S. Navy, Norfnlk.

Project Director, Roosevelt Stadium Historic American Buildings survey Documentation Project, Jersey City, New Jersey, for the City of Jersey City.

Project Director, Historic American Engineering Recoord Documentation of the Erie-Lackawanna Coal Trestle, Jersey City, New Jersey, for the City of Jersey city.

Project Director, Route 92 Cultural Resources Study, Technical Environmental Study. Mercer, Middlesex, and Somerset. Counties, New Jersey, for the New Jersey Department of Transportation.

Project Directori, Phase III M1t1gation, Abbott Falm Plujecl, Ruutes I-195, I-2y்j, N.J. 29, and N.J. 129 near Trenton N.J., for the New Jersey Department of Transportation.

Project Director, Cultural Resource Survey. Part of Environmental Impact statement, Newport City, Jersey City. New Jersey, for Dresdner \& Associates.

Project Director, Phase I and II Árchaeological Investigation of the Washington Street Urban Renewal Area, Site 1 for Shearson Lehman/American Express, New York, New York.

Project Director, Phase I, II, and III cultural resource investigation of a block in Wilmington, Delaware, for the Commerce Department, City of Wilmington. 
Principal Archaeologist, Cultural Resources Investigations For Peacekeeper ( $M X)$

Environmental Impact Assessment.

Cheyenne, Wyoming.

Project Director, Resource Inventory 1 for Georgia Power Company, Burke,

Effingham, and Screven Counties, Georgia.

Project Director, Phase III Cultural

Resource Mitigation of Prehistoric Sites, Iowa Great River Road Project, Louisa County, Iowa, For the Iowa Department of Transportation.

Project Director, Phase I, II, and III Documentary Research, Archaeological Assessment, and Mitigation, Barclays Bank Site, Manhattan, New York.

Project Director, Phase II Cultural Resource Survey, Abbott Farm Project, Routes I-195, I-295, N.J. 29, and N.J. 129, near Trenton N.J., for the New Jersey Department of Transportation.

Project Director, Lower Raritan River Multipurpose Study, Cultural Resource Reconnaissance, Middlesex and Somerset Counties, N.J., for the United States Army Corps of Engineers.

Project Director, Phase II Cultural Resource Survey, Route U.S. 206 between Princeton and Somerville, N.J., for the New Jersey Department of Transportation.

Project Director, Phase II Cultural Resource Survey, Routes U.S. 22 and I-78 Interchange, Still Valley, Greenwich and Pohatacong Townships, N.J., for the New Jersey Department of Transportation.

Project Director, Phase II Cultural Resource Survey, Route N.J. 31 between Flemington and Clinton, N.J., for the New Jersey Department of Transportation.

* Research Fellow in Anthropology, Smithsonian Institution.

Position involved independent research based on the collections of the Smithsonian. Current research involves the 
analysis of $39 \mathrm{ST} 1$, a multi-component archaeological site located in South Dakota which was excavated as part of the post-World II Interagency Archaeological Salvage Program in the Missouri River Basin. Also involved in test excavations at $18 \mathrm{Ch} 89$, a prehistoric ossuary in Maryland.

* Archaeological Consultant, Dennett Muessig \& Associates.

Position involved assisting in proposal preparation, archaeological fieldwork and photography, and establishing ground controls tor photographic mapping of structures and archaeological sites. Involved in photographic mapping of a Metro tunnel in Washington, D.C. to identify tights, and photogrammetric mapping of the Gallery Row project, Washington, $D . C$. and of the excavation on the grounds of Plum Grove, a former governor's home in Iowa City, Iowa.

* Archaeologist, Iowa Department of Transportation.

Designed a preservation and development plan for an archaeological site acquired as part of the Iowa Great River Road project. Coordinated with state Historic Preservation officer, Federal Highway Auministration, Iowa Conservation Commission, and Tnwa Native Americans.

* Archaeological Consultant, Iowa State University.

Establ1shed ground controls for excavations at Buxton, Iowa, a defunct coal mining town.

1970 to 1980

* Director of Transportation Archaeology for the Iowa Department of Transportation cultural Resouree surveys contract, office of the state Archaeologist, University of Iowa.

Position involved directing surveys along proposed highway corrldors, testing sites for eligibility to the National Register of Historic Places, and conducting mitigation- level excavations. Directed Historic American Buildings Survey 
recording of Gothic Revival dwelling in Knoxville, Iowa, excavations at the Lambert Site, a Woodland camp on the Des Moines River, and the cultual and natural resources survey of the Iowa Great River Road. All involved assembling and managing interdisciplinary teams of archaeologists, historians, historical architects, geologists, and ecologists.

* Senior Research Scientist, University of Iowa (position concurrent with Directorship of Transportation Archaeology Program, which was run under annual contracts between the university and the Iowa Department of Transportation).

* Adjunct Lecturer, Department of Anthropology, University of Iowa.

Taught courses in laboratory analysis, field methodology, site surveying, and mapping. Also supervised independent study students.

* Director, Iowa Archaeological Site Records Inventory, Office of the state Archaeologist.

Position involved correcting and updating existing site records and compiling all new site records filed with the state Archaeologist.

* Project Director, Office of the State Archaeologist.

Position involved the excavation of an archaic ossuary in councll Bluffs, Iowa (as a result of this project revisions were made to the Iowa Code providing for cooperation between Native Americans and archaeologists), the excavation of a Central Plains earthlodge at the Glenwood State School, Glenwood, Iowa, and the survey of cultural resources to be impounded by the Waubonsie Reservoir, Milis and Fremont Counties, Iowa.

* Director of Salvage Archaeology, Iowa Department of Transportation.

Position involved the direction of excavations of 14 earthlodges and a Woodland site within the zone of impact of the relocation of Highway 34 , Glenwood, Iowa. 
* Project Coordinator, MACos Project, University of Iowa.

Position involved coordinating joint research between the Anthropology and Education Departments.

1965 to 1969

Instructor of Social Sciences, Morris Harvey College.

* Instructor, Adult Education Program, West Virginia University.

* Faculty Advisor, Pi Gamma Mu (Social Science Honorary), Morris Harvey College. 


\section{RESUME}

NAME :

EDUCATION :

PROFESSIONAL REGISTRATION :

PROFESSIONAL AFFILIATIONS :

EXPERIENCE :

1984 to Present
Charles H. LeeDecker

M.A., Anthropology, The George Washington University, 1978 . B.A., Anthropology, Cornell University, 1970.

Accredited by the Society of Professional Archaeologists in Field Research and Cultural Resource Management

Society of Professional Archaeologists Society for American Archaeology Society for Historical Archaeology

Senior Archaeologist, Berger, Barnard \& Thomas Engineering, Inc.

Principal Investigator for archaeological data recovery at Block 1184, Wilmington, Delaware.

Principal Investigator for laboratory analysis of the Assay Site collections, Block 35, New York City.

Co-Principal Investigator for testing and data recovery at the Christina Gateway Project; wilmington, Delaware.

Principal Investigator for archaeological testing and data recovery at the Howard Road Historic District, Washington, D.C.

principal Investigator for archaeological survey of 14 District of Columbia Department of Recreation Properties.

Principal Investigator for archaeological testing of three sites at Marine Corps Base, Camp Lejeune, North Carolina.

Principal Investigator for archaeological survey of Jones Point Park, Alexandria, Virginia.

Project Archaeologist for preliminary archaeological assessment of a proposed parking facility at Squares 803 and 804 , District of Columbia. 
Resume - Charles H. LeeDecker

Page Two

EXPERIENCE :

(continued)

1981 to 1984 * Senior Archaeologist and Branch Manager, Soil systems Division, Alexandria, virginia.

Responsible for administration, long-term planning and business development in the Middle Atlantic region. Directed archaeological studies for East Tennessee Natural Gas Transmission Corp. pipeline expansion in southwest Virginia; National Photographic Interpretation Center building addition, Washington, D.C.; Philadelphia's Fairmount Park; Felsenthal National Wildlife Refuge, Arkansas; Fort Belvoir, Virginia; Raritan Township Municipal Authority 201 Plan, New Jersey; etc.

1980 to 1981 * Fresident, Leevecker \& Associates. Springfield, Virginia. Dlrected cultural resource projects for the Caruthersville Harbor, Missouri; four dredge disposal sites in Dorchester County, Maryland; Belena and Vicinity, Arkansas; and La Grue Bayou, Arkansas.

1976 to 1980 * Archaeologist, Iroquois Research Institute, Fairfax, Virginia.

Eutablished and managed the Institute's Branch office in Memphis, Tennessee. Responsible for preparation of research proposals and direction of more than 30 archaeological projects throughout midwestern and southeastern states. Major projects include intensive survey and testing of 200 miles of drainage ditch improvements in the St. Francis River Basin, Arkansas and Missouri; archaeological survey and testing of 7,400-acre Gathright Lake, Virginia; prepara- 
Resume - Charles H. LeeDecker

Page Three

EXPERIENCE :

(continued)

1975

tion of cultural resource management guidelines

for the Federal Power Commission; survey of

14,000 acre Taylorsville Lake, Kentucky;

archaeological resource management plan for Perry

Lake, Kansas; archaeological reconnaissance and

predictive model for 110,000 acre flood easement

Iands at Truman Dam, Missouri.

Archaeological excavations and laboratory processing at the Shawnee-Minisink Site, a multicomponent stratified site in the Upper Delaware River Valley, Pennsylvania.

1974 to 1975 Student Intern, Smithsonian Institution, Museum of Natural History, Conservation Laboratory. Conservation and restoration of archaeological. and ethnographic collections.

Feb. 1971 to

Aug . 1974

Human Resources Development Specialist, Bureau of Employment Security, York, Pennsylvania, Assisted disadvantaged persons to find suitable employment or job training.

TECHNICAL REPORTS:

1977

Co-author and Project Coordinator of Archaeological and Historical Investigations for Energy Facilities: A state of the Art Report. Submitted to the office of Energy Systems, Federal Power Commission.

1977

Contributing author of The Cultural Resources of Clinton Lake, Kansas: An Inventory of Archaeology, History and Architecture. Submited to the U.S. Army Corps of Engineers, Kansas City District.

1977 . Senior author of Preliminary Management Plan for Cultural Resources, Perry Lake, Kansas. Submitted to the U.S. Army Corps of Engineers, Kansas City District.

1977 Senior co-author of Cultural Resources Studies: Tuttle Creek Lake and Marysville Flood Study Area, Big Blue River, Kansas. Submitted to the U.S. Army Corps of Engineers, Kansas City, District. 
Resume - Charles H. LeeDecker

Page Four

TECHNICAL REPORTS :

(Continued)

1977

Co-author of Testing-Mitigation at $44 \mathrm{BA} 25$,

Gathright Lake Project, Virginia. Submitted to the U.S. Army Corps of Engineers, Norfolk District.

Contributing author of Cultural Resources Management Plan for New Melones Project Area, California. Submitted to the U.S. Army Corps of Engineers, Sacramento District.

Contributing author of The cultural Resources of Lowes Island, Virginia. "submitted to the falriax County Water Authority.

Principal Investigator and senior author of $A$ Survey Level Report of Locust Creek, Greene County, Arkansas: Archaeology, History and Architecture. Submitted to the U.S. Army Corps of Engineers, Memphis District.

Principal Investigator and senior author of $A$ Reconnaissance Level Report of the Belle Fountain Ditch and Tributaries Project, Mississippi County, Arkansas and Dunklin \& Pemiscot Counties, Missuuri: Archaeology, History and Architecture. Submitted to the U.S. Army Corps of Engineers, Memphis District.

Principal Investigator and senior author of $A$ Survey Level Report of Ditches $70,71,21 \mathrm{~A}$ anld 25 Channel Enlargement Project, Mississippí County, Arkansas. Submitted to the U.S. Army Corps of Engineers, Memphia District.

Principal Investigator and senior adthor of $A$ Survey Level Report of the Ditch 19 Channel Enlargement project, Dunklin County, Missouri. Submitted to the U.S. Army Corps of Engineers, Memphis District.

Principal Investigator and senior author of $\underline{A}$ Survey Level Report of the Buffalo Creek Diversion Project, Craighead and Mississippi Counties, Arkansas. Submitted to the U.S. Army Corps of Engineers, Memphis District.

Contributing author of Predicting Cultural Resources in the St. Francis River Basin: A Research Design. Submitted to the U.S. Army Corps of Engineers, Memphis District. 
Resume - Charles H. LeeDecker

Page Five

TECHNICAL REPORTS :

(Continued)

1978

1978

Principal Investigator and senior author of $A$ Survey Level Report of the Castor River Ditch Enlargement Project, Item 1, stoddard County Missouri. Submitted to the U.S. Army Corps of Engineers, Memphis District.

Principal Investigator and senior author of $\underline{A}$ Survey Level Report of the Madison to Highway 64 Channel Cleanout Project, Item 2, Cross and st. Francis Counties, Arkansas. Submitted to the U.S. Army Corps of Engineers, Memphis District.

1978

Principal Investigator and senior author of $\underline{A}$ Survey Level Report of the Ditch 24 Channel Enlargement project, Stoddard County, Missouri. Submitted to the U.S. Army Corps of Engineers, Memphis District.

Principal Investigator and senior author of $\underline{A}$ Survey Level Report of the Ditch 27 and Tributaries Channel Enlargement Project, Mississippi County, Arkansas. Submitted to the U.S. Army Corps of Enginers, Memphis District.

1979 Principal Investigator and senior author of $\mathrm{A}$ Survey Level Report of the Blackfish Bayou Channel Enlargement Project Items 2 and 3 , Crittenden and st. Francis Counties; Arkansas. Submitted to the U.S. Army Corps of Engineers, Memphis District.

Senior co-author of A Prioritization Plan for the Conservation of Historical, Archaeological and Architectural Resources at Gathright Lake, Virginia. Submitted to the U.S. Army Corps of Engineers, Norfolk District.

1979

Contributing author of Inventory and Evaluation of Archaeological Resources of Clinton Lake, Kansas, and Mitigation of Potentially Eligible sites. Draft report submitted to the U.S. Army Corps of Engineers, Ransas City District.

1979

Principal Investigator and senior author of $\underline{A}$ Survey Level Report of the Wappapello to Crowleys Ridge Channel Cleanout and Scour Repair Project, Butler and Stoddard Counties, Missouri. Submitted to the U.S. Army Corps of Engineers, Memphis District. 
Resume - Charles H. LeeDecker

Page Six

TECHNICAL REPORTS:

(Continued)

1979

Principal Investigator and senior author of $\underline{A}$ Survey Level Report of the Big Creek Channel Enlargement Project, Item 2, crittenden County, Arkansas. Submitted to the U.S. Army Corps of Engineers, Memphis District.

1979

Principal Investigator and senior author of $A$ Survey Level Report of the Castor River Chanñel Enlargement project, Item 2, Bollinger and stoddard Counties, Missouri. Submitted to the IJ.S. Army Corps of Engineers, Memphis District.

1979

Principal Investigator and senior author of $\mathrm{A}$ Survey Level Report of the Honey Cypress Ditch Enlargement Project, Dunklin County, Missouri and Mississippi County, Arkansas. Submitted to the U.S. Army Corps of Enginears, Memphio District.

1979 Principal Investigator and senior author of $\underline{A}$ Preliminary Report of Stations $0+00$ to $50+60$ of the Big Creek Enlargement and Diversion Project, Item I, Crittenden County, Arkansas. Submitted to the U.S. Army Corps of Engineers, Memphis District.

1980

Principal Investigator and senior author of Prehistoric Archaeological Reconnaissance in the Harry S. Truman Dam and Raservole 50 Year Floü Easement Lands, osage River Basin, Missouri. Submilted to the U.S. Army Corps of Engineers, Kansas City District.

1980

Principal Investigator and senior author of $I_{n}=$ terim Report of Cultural Resource Survey and Testing of stations $50+60$ to $196+00$ of the Big Creek Enlargement and Diversinn Projoct, Crittenden County, Arkansas. Submitted to the U.S. Army Corps of Engineers, Memphis District.

1980

principal Investigator and senior author of $A$ survey Level Report of the Upper Buffalo Ditch Enlargement Project, Dunklin County, Missouri and Mississiopi County, Arkansas. Submitted to the U.S. Army Corps of Engineers, Memphis District.

1980

Principal Investigator and author of $A$ Survey Level Report of the Caruthersville Harbor Project, Pemiscot County, Missouri. Submitted to the U.S. Army Corps of Engineers, Memphis District. 
Resume - Charles H. LeeDecker

Page Seven

TECHNICAL REPORTS :

(Continued)

1981

Principal Investigator and author of $A$ Cultural

Resource Reconnaissance of Four Federal Maintenance Dredging Projects in Dorchester County, Maryland. Submitted to the U.S. Army Corps of Engineers, Baltimore District

1981

Principal Investigator and senior author of $A$ Cultural Resource Reconnaissance of the Heleña, Arkansas and Vicinity Project, Phillips County, Arkansas. Submitted to the U.S. Army Corps of Engineers, Memphis District.

1981

Principal Investigator and author of A Cultural Resource Survey of the La Grue Bayou Permit Area, Prairie County, Arkansas. Submitted to the U.S. Army Corps of Engineers, Memphis District.

1982

Principal Investigator and author of Phase II Archaeological Investigation of Sites $44 \mathrm{WM} 164$ and 44WMI82, Clifford Hutt Property, Westmoreland County, Virginia. Submitted to the U.S. Army Corps of Engineers, Baltimore District.

1982

Principal Investigator and author of Archaeological Assessment of the Fort McNair Metrobus Garage Facility, Southwest Washington, D.C. Submitted to Skidmore, Owings \& Merrill Architects, Washington, D.C.

1982

Contributing author to Archaeological Investiga.tions at the National photographic Interpretation Center Addition, Washington, D.C. Navy Yard Annex. Submitted to Leo A. Daly Architects, Washington, D.C.

Principal Investigator and senior author of Phase II Archaeological Investigation of Sites $44 W \overline{G 248}$ and 44WG249 on the East Tennessee Natural Gas Company Transmission Line Expansion, Washington County, Virginia. Submitted to East Tennessee Natural Gas Company, Knoxville, Tennesse.

Principal Investigator and senior author of Phase I Archaeological Investigation of Segment $\mathrm{J} 2$ of the Franconia-Springfield Metrorail Line, Fairfax County, Virginia. Submitted to Wallace, Roberts and Todd, Philadelphia, Pennsylvania. 
Resume - Charles H. LeeDecker

Page Eight

TECHNICAL REPORTS :

(Continued)

1983

Principal Investigator and senior author of Phase I Archaeological Investigation of segment $\mathrm{Hl}$ of the Franconia-Springfield Metrorail tine, Fairfax County, Virginia. Submitted to Wallace, Roberts and Todd, Philadelphia, Pennsylvania.

1983

Project Manager for Phase I Archaeological Investigation of National Park Service Lands in the vicinity of Chain Bridge, District of Columbia and Virginia. Submitted to the Arlington County Department of Public Works.

1983

Project Manager for A Phase II Investigation of the Prehistory and History of Five sites in St. Mary's County, Maryland. Submitted to the Southern Maryland Electric cooperative, Inc.

1983

Principal Investigator for Phase I Archaeological Investigation of the Fairfax Yacht Club Occoguan Marina. Submitted to Marine Structural Applications, Inc.

Principal Investigator for stage IA Cultural Resource Survey of the Raritan Township Municipal Authority 201 Plan, Hunterdon County, New Jersey. Submitted to AEPCO, Inr:

1983

projeet Manayei for A Phase 1 Archaeological Survey of the Proposed Nokesville Community Park, Prince William County, Virginia. Submitted to the Prince William County Park Authority.

Principal Investigator for U.S. Environmental protection Agency Stage lB Surveys in New Jorsey, An Assessment of Archaeological Sampling Procedures. Prepared for the office of Historic Preservation, New Jersey Department of Environmental protection.

Principal Investigator for Survey for Archaeological and Historical Resources Along the WMATA E-Route from Fort Totten Drive to the District Line. Submitted to Wallace, Roberts and Todd.

Principal Investigator for Phase I Archaeological Investigation of the Academy Apartments, West Point, Virginia. Submitted to the American Development Group, Inc. 
Resume - Charles H. LeeDecker

Page Nine

TECHNICAL REPORTS :

(Continued)

1983

Principal Investigator for Managing Archaeological Resources in Fairmont Park. Submitted to Wallace, Roberts and Todd.

1984

Project Archaeologist for Archaeological Testing of Twelve Sites in the Felsenthal Navigation Pool and National Wildlife Refuge, Arkansas. Submitted to the U.S. Army Corps of Engineers, Vicksburg District.

1984

Project Manager and Co-principal Investigator for Cultural Resource Survey and Evaluation at Fort Belvoir, Virginia. Submitted to the National Park Service, Mid-Atlantic Region.

1984

Principal Investigator for Phase II Archaeological Investigation of the Eisenhower Avenue Earthwork Site, City of Alexandria, Virginia. Submitted to Wallace, Roberts and Todd and the Washington Metropolitan Area Transit Authority.

1984

Principal Investigator for Preliminary Archaeol ogical Assessment of Fourteen Department of Recreation Properties in the Anacostia Section, District of Columbia. Submitted to the Department of Recreation, District of Columbia.

1985

Principal Investigator for Archaeological Survey of a Proposed Bike Path, Foot Path and Soccer Fields at Jones Point Park, Alexandria, Virginia. Submitted to the City of Alexandria and the National Park Service, Natiunal Capital Region.

Principal Investigator for Archaeological Testing of Sites 31CN348,310N281 and 310N350, Marine Corps Base Camp Lejeune, Onslow County, North Carolina. Submitted to the Naval Facilities Engineering Command, Norfolk.

Co-principal Investigator for Nineteenth Century Wilmington Households: The Christina Gatcway Project Submitted to the Department of Commerce, City of wilmington.

Principal Investigator for Historical and Archaeological Assessment of Two Proposed Satellite Parking Lots, Squares 702 and 703 , Washington, n.C. Submitted to the Washington Metropolitan Area Transit Authority. 
Resume - Charles H. LeeDecker

Page Ten

TECHNICAL REPORTS:

(Continued)

1985

Co-Principal Investigator for Nineteenth-century Wilmington Households: The Christina Gateway

Project. Submitted to the Department of Commerce, City of Wilmington, Delaware.

1985

Principal Investigator for Archaeological, Architectural, and Historical Investigations at the Howard Road Historic District, Washington, D.C. Submitted to wallace Roberts \& Todd and the Washington Metropolitan Area Transit Authority.

1985

Principal Investigator for Cultural Resource study at the Marine Corps Development and Education Command. Submitted to Bairley \& MaGinniss, P.C. for Marine Corps Development and Command, Quantico, Virginia.

1986

Principal Investigator for Preliminary Historical and Archaeological As sessment of the Langston Terrace Project, washington, D.C. Submitted to Glen B. Leiner, Architectural Historian.

Co-author of Re-Evaluation of Rural Historic Contexts for the Fort Drum, NY Vicinity. Submitted to the National Park Service, Mid-Atlantic Region.

Principal Investiqator for Phase I Archaeological Survay of the Md. Rugte 28 Tmerovement Project, Montgomery County, Maryland. Snhmittad to the Maryland Department of Transportation.

PUBLICATIONS AND PAPERS PRESENTED:

1984

"U.S. Environmental Protection Agency - Region II Stage IB Surveys in New Jersey: An Assessment of Archaeological Sampling Techniques". In Historic preservation Planning in New Jersey: Selected Papers on the Identification, Evoluation, and protection of Cultural Resources. Office of New Jersey Heritage, Trenton.

"From House to Outhouse: A Study of Nineteenth Century Households in Wilmington, Delaware." With Terry Klein, Amy Friedlander and Cheryl Holt. Presented at the Society for Historical Archaeology Annual Meeting, Boston and at the Middle Atlantic Archaeological Conference, Rehoboth Beach. 
Resume - Charles H. LeeDecker

Page Eleven

PUBLICATIONS AND PAPERS PRESENTED:

(CONTINUED)

1985

"Filling the Middle-Range Theory Gap in Urban Archaeology: A Household Paradigm." With Amy Friedlander. Presented at the 84 th Annual Meeting of the American Anthropological Association, Washington, D.C.

1987

"Nineteenth Century Households and Consumer Behavior in Wilmington, Delaware." With Terry Klein, Amy Friedlander and Cheryl Holt. In Socio-Economic Status and Consumer Choices: Perspectives in Historical Archaeology. Suzanne Spencer-Wood, editor. Plenum Press. 
NAME :

EDUCATION :

PROFESSIONAL AFFILIATIONS :

EXPERIENCE:

1986 to Present
Claudia Croy Holland

M.A. anthropology, Louisiana State

University, Baton Rouge, 1986

B.A., anthropology, Florida state

University, Tallahassee, 1979

Society for Historical Archaeology

Southeastern Archaeological Conference

LAMAR Briefs

Material Culture Bulletin

Council nf Texas Archoologioto
*Archaeologist, Berger, Barnard \& Thomas Engineering, Inc.

Directing field teams, developing mitigation plans, report preparation, proposal writing, and solicitation of cultural resource management projects.

Principal Investigator, Background Research for cultural resource assessment for proposed prison site in La Tuna, 'lexas, for the Federal Bureau of Prisons.

Cowprincipal Investigator, Field reconnaissance and background research of a proposed Federal Correctional Center, in Three Rivers, Texas for the Federal Bureau of Prisons.

Principal Investigator, Fort Drum Cultural Resource Inventory, Watertown, New York for the National Fark Gervile, Mid-Atlantic Region, and the U.S. Army. Phase II investigations of a 19 th-century farmstead.

* Research Associate, Department of Geography and Anthropology, Louisiana State University, Baton Rouge.

Directed a public archaeology project at an historic site in downtown Shreveport, LA. Responsible for analysis of artifacts, historical research, and report writing.

*Field Supervisor, field school in historical archaeology, sponsored by Louisiana State University. 
1983 to 1985

1984

1984

1983

1982 to 1983

1982

1982

1981 to 1982

1981
Assisted in teaching archaeological field techniques and identification of historic artifacts to 23 college students.

*Graduate Research Assistant, Department of Geography and Anthropology, Louisiana State University, Baton Rouge.

*Field Assistant, First Cemetery of New Orleans, Louisiana.

Created site map, assisted in supervising data recovery, and conducted archival and historical research about the site.

*Field Director, Oakley Plantation, Audubon State Commemorative Area, West Feliciana Parish, Louisiana.

Directed a controlled surface collection and mapping project of buildings and other features associated with the main house, participated in artifact analysis and report preparation.

*Archeological Field Technician and photographer, Ft. Raleigh National Historic Site, National Park Service, Roanoke Island, NC.

*Archaeological Technician, cultural resource management, National Park Service, Southeast Archeological Center, Tallahassee, Florida.

Organized and curated written and illustrative materials from WPA excavations.

*Archeological Field Technician, Cumberland Island National Seashore, National Park Service, GA.

*Laboratory Technician, Big Cypress National preserve collection, National Park Service, Southeast Archeological Center, FL.

*Laboratory Director, Millwood Plantation Project, Loyola University of Chicago. .

Supervised 8 lab workers in the analysis of over 60,000 historic artifacts.

*Archaeologist, Millwood Plantation Project, Abbeville County, SC and Elbert County, GA, Loyola University of Chicago. 
1980 to 1981

1980

1979 to 1980

1978 to 1979

1978

1975 to 1976
*Wakulla District Archeologist, USDA - Forest Service, Apalachicola National Forest, Crawfordville, FL.

Responsible for survey and limited testing of sites, artifact analysis, and report writing, as well as supervision of YCC groups.

*Archeological Field Technician;. St. Marks Wildlife Refuge, Wakulla County, FL. Southeast Archaeological Conservation Center, Florida State University, Tallahassee.

*Archeological Field and Laboratory Technician, Big South Fork National River and Recreation Area, Tennessee and Kentucky, Nationel Park Service.

*Undergraduate Assistant, Underwater Archaeological Research Section, Florida Department of State, Division of Archives, History, and Records Management, Tallahassee.

Publio information, assisted in organizing the 1979 Conference on Underwater Archaeology.

*Student in archaeological field school, st. Augustine, FL, sponsored by Florida State University.

*Teaching nooistant, Guided studies program, Tallahassee Community College, Tallahassee, FL.

PUBLICATIONS AND TECHNICAL REPORTS:

"Everything on That Land Was Yours Except That Bale of Cotton": the Archaeological

Manifestations of a Share Renter's House on a Cotton Plantation in the South Carolina Piedmont. To appear in Mrchaeologieal Perspectives on Farm Tenancy in the Eastern United States, edited by William H. Adams and Stephanie Rodeffer.

Public Archaeology at a Late Nineteenth-to Late Twentieth-Century Urban Housesite, Shreveport, Louisiana. Report submitted to the Division of Archaeology, State of Louisiana.

(with, Douglas W. Owsley, Charles E. Orser, Jr., and Robert Montgomery). An Archaeological and Physical Anthropological Study of the First Cemetery in New Orleans. Report submitted to the Louisiana Division of Archaeology. 
(with Charles E. Orser, Jr.). Let Us Praise Famous Men, Accurately: Toward a More Complete Understanding of Postbellum Southern Agricultural Practices. Southeastern Archaeology 3(2):111-120.

(with Charles E. Orser, Jr.). A Preliminary Archaeological Investigation of Oakley Plantation, Audubon State Commemorative Area, West Feliciana Parish, Louisiana. Report submitted to the Louisiana Division of Archaeology.

$1980 \mathrm{a}$

$1980 \mathrm{~b}$

$1980 \mathrm{C}$

PROFESSIONAL PAPERS :

1985

1984

1983
Archeological Survey and Testing of Proposed Sewage Line Reconstruction within the Wakulla District of the Apalachicola National Forest, Leon County, Florida. On file at USDA - Forest Service, Tallahassee, Fl.

A Cultural Resources Survey of Proposed Land Exchange Tract W-1842 within the Wakulla District of the Apalachicola National Forest, Leon County, Florida. On file at USDA - Forest Service, Tallahassee, Fl.

Archeological Survey and Testing within the Proposed City of Tallahassee Land Exchange within the Wakulla District of the Apalachicola National Forest, Leon County, Florida. On file at USDA - Forest Service, Tallahassee, Fl. (with Peter B. Mires). The Discovery and Investigation of the st. Peter street Cemetery in New Orleans. Presented at the 18 th annual meeting of the society for Historical. Archeology, Boston, Massachusetts.

Status Differentiation at a Postbellum Plantation: Millwood Plantation. Presented at the 17 th annual meeting of the Society for Historical Archaeology, Williamsburg, Virginia.

(with Judy I. Hellmich). A Pictorial Essay of the WPA in the Southeastern United States. Presented at the 35 th annual meeting of the Florida Anthropological Society, Tallahassee, Florida.

ACADEMIC AWARDS: Robert $C$. West Field Research Award, 1984. Louisiana State University, Department of Geography and Anthropology. 
